\author{
UNIVERSIDADE DE SÃO PAULO \\ INSTITUTO DE RELAÇÕES INTERNACIONAIS \\ PROGRAMA DE PÓS-GRADUAÇÃO EM RELAÇÕES INTERNACIONAIS
}

ISABELLA DUARTE FRANCHINI GREB

\title{
A AMEAÇA TERRORISTA NA AMÉRICA DO SUL: UMA ANÁLISE DO DISCURSO NA ERA BUSH
}

São Paulo

2015 


\author{
UNIVERSIDADE DE SÃO PAULO \\ INSTITUTO DE RELAÇÕES INTERNACIONAIS \\ PROGRAMA DE PÓS-GRADUAÇÃO EM RELAÇÕES INTERNACIONAIS
}

\title{
A AMEAÇA TERRORISTA NA AMÉRICA DO SUL: UMA ANÁLISE DO DISCURSO NA ERA BUSH
}

Isabella Duarte Franchini Greb

Dissertação apresentada ao Programa de

Pós-Graduação em Relações Internacionais do Instituto de Relações Internacionais da Universidade de São Paulo, para a obtenção do título de Mestre em Relações Internacionais Programa de Pós-Graduação em Relações em Internacionais

Orientador: Prof. Dr. Rafael Duarte Villa

São Paulo

2015 
Autorizo a reprodução e divulgação total ou parcial deste trabalho, por qualquer meio convencional ou eletrônico, para fins de estudo e pesquisa, desde que citada a fonte.

Franchini, Isabella.

A Ameaça Terrorista na América do Sul: Uma Análise do Discurso na Era Bush/ Isabella Duarte Franchini Greb; orientador Rafael Antonio Duarte Villa. - São Paulo, 2015-05-19

$123 \mathrm{f} .:$ il.

Dissertação (Mestrado) - Instituto de Relações Internacionais, Universidade de São Paulo, 2015.

1. Terrorismo - América do Sul. 2. Securitização. 3. Análise crítica do discurso. 
Nome: FRANCHINI, Isabella Duarte Greb

Título: A Ameaça Terrorista na América do Sul: Uma Análise do discurso

Dissertação apresentada ao Instituto Relações Internacionais da Universidade de São Paulo para obtenção do título de Mestre em Relações Internacionais

Aprovada em:

Banca examinadora

Prof. Dr.

Instituição:

Assinatura:

Prof. Dr.

Instituição:

Assinatura:

Prof. Dr.

Instituição:

Assinatura: 
À vó Cida, à vó Zuleika e ao tio Paulinho, Com todo amor e toda saudade. 


\section{Agradecimentos}

Aos meus pais, Lívia e Hélio, a quem devo a vida;

Ao meu marido, meu grande amor e melhor amigo, Thorsten, ao meu filho canino, Dudu, e à minha filha felina, Lizzie;

Ao meu irmão, meu grande exemplo, Helinho, à minha cunhada-irmã, Ivy, e minha sobrinha-princesa Sophie;

À minha família no Brasil e à minha família na Alemanha;

Aos meus amigos e mentores, Hamilton, Paul, Clóvis, Dudu Lobo, Peterson, Lynn, Suzi, Robélia, Ana Paula, Ernst, Peter, Annabelle, Xian-Ling, Hamoon, Kelly, Aisha, Naseer, Naufal, Malene e Jane;

Aos meus professores e amigos do curso de graduação em Relações Internacionais da PUC-SP; da Universidade de Coimbra, e do curso de graduação em Letras da FFLCHUSP.

Ao Instituto de Relações Internacionais da Universidade de São Paulo (IRI-USP), à querida Giselle, à Beth, à Professora Janina, aos professores, aos colegas e amigos da pós-graduação;

Ao Mestre Oliveiros;

Especialmente, ao meu orientador, Professor Rafael Duarte Villa,

minha incondicional gratidão, estima, admiração e respeito.

Cingapura, maio de 2015. 
"Ich möchte wissen, was die Welt im Innersten zusammenhält!"

Goethe 


\section{Resumo}

FRANCHINI, Isabella D. G. A ameaça terrorista na América do Sul: uma análise do discurso na Era Bush. Dissertação (Mestrado em Relações Internacionais) -Instituto de Relações Internacionais, Universidade de São Paulo, São Paulo, 2015.

Esta pesquisa de Mestrado, sob a forma de dois artigos distintos, mapeia articulações da ameaça terrorista que possam sugerir a macrossecuritização da Guerra ao Terror na América do Sul, nos discursos dos presidentes de Brasil, Colômbia e Venezuela na Assembleia Geral das Nações Unidas (2002-2006). Com base na Teoria das Securitizações da Escola de Copenhague e na Análise Crítica do Discurso de vertente anglo-saxã, identificam-se as estratégias linguísticas e o encadeamento argumentativo da securitização do terrorismo no ato de fala. Conclui-se que, no nível discursivo, Colômbia e Venezuela macrossecuritizaram a Guerra ao Terror, instrumentalizando o terrorismo para justificar as ações dos Governos Uribe e Chávez , enquanto o Governo Lula absorve o terrorismo ao combate à fome.

Palavras-chave: Guerra ao Terror - Macrossecuritização - América do Sul - Análise Crítica do Discurso - Retórica. 


\section{Abstract}

FRANCHINI, Isabella D. G. The Terrorist Threat in South America: A Discourse Analysis in the Bush Era Dissertação (Mestrado em Relações Internacionais) Instituto de Relações Internacionais, Universidade de São Paulo, São Paulo, 2015.

This Master's research, in the form of two separate articles, maps the articulation of the terrorist threat that might suggest a macrosecuritisation of the "War on Terror" in South America, in the speeches of presidents of Brazil, Colombia and Venezuela in the United Nations General Assembly (2002 -2006). Based on the Theory of Securitisation of the Copenhagen School and Critical Analysis of the Anglo-Saxon Critical Discourse Analysis, it identifies the linguistic strategies and argumentative textual chaining of terrorism securitisation in the speech act. We conclude that, in the discursive level, Colombia and Venezuela have macrosecutirised the War on Terror, using terrorism to justify the actions of Uribe and Chavez governments, while the Lula embodies the danger of terrorism to its anti-hunger program.

Key-words: War on Terror - Macrosecuritisation - South America - Critical Discourse Analysis - Rhetoric. 


\section{Sumário de Figuras}

Figura 1. Modelo tridimensional da Análise do Discurso .................................46

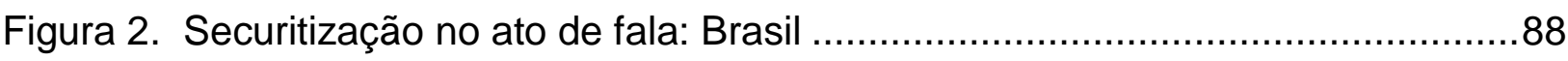

Figura 3. Encadeamento argumentativo: Brasil .............................................. 89

Figura 4. Securitização no ato de fala: Colômbia ........................................101

Figura 5. Encadeamento argumentativo: Colômbia....................................... 101

Figura 6. Securitização no ato de fala: Venezuela .......................................115

Figura 7. Encadeamento argumentativo: Venezuela ...........................................116

\section{Sumário de Tabelas}

Tabela 1. Ocorrências explícitas "terrorismo" nos discursos de Brasil (1999-2006) .....88

Tabela 2. Ocorrências explícitas "terrorismo" nos discursos de Colômbia (1999-2006)

Tabela 3. Ocorrências explícitas "terrorismo" nos discursos de Venezuela (1999-2006) 


\section{Sumário}

Artigo I: A Análise do Discurso nos Estudos de Segurança Internacional: uma

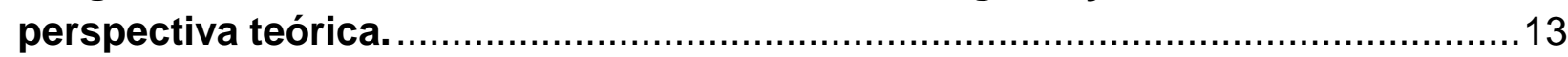

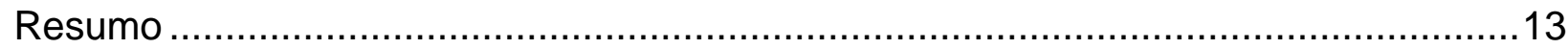

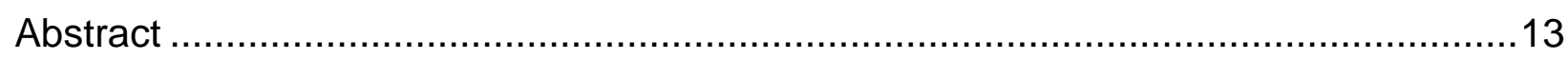

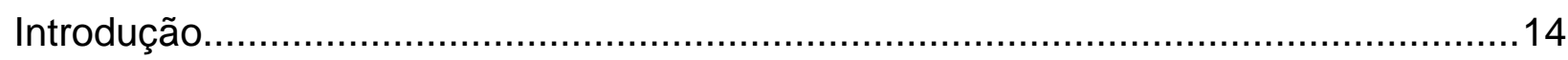

1. A Análise do Discurso nas Relações Internacionais: da anarquia à desconstrução.. 15

1.1. Realismo e Liberalismo: o debate positivista.................................................15

1.2. Pós-positivismo: do construtivismo à desconstrução .......................................19

1.3. Análise do Discurso em Segurança Internacional ..........................................26

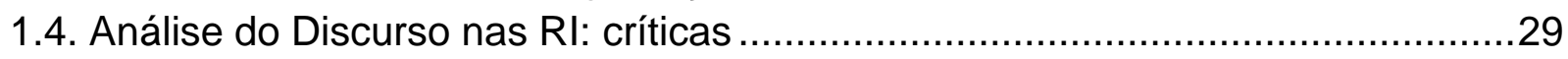

2. Marco teórico: Escola de Copenhague ……..........................................................

2.1. O Complexo de Segurança Sul-americano e a macrossecuritização da

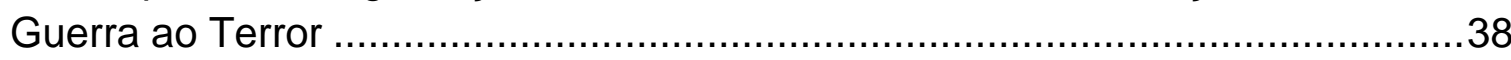

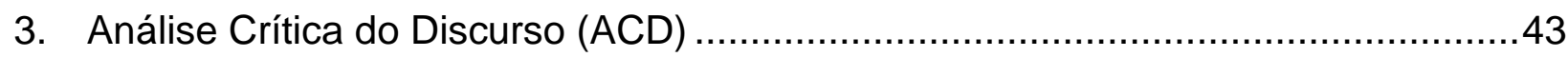

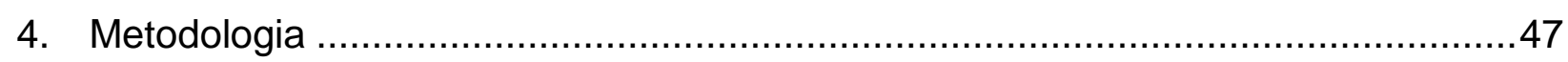

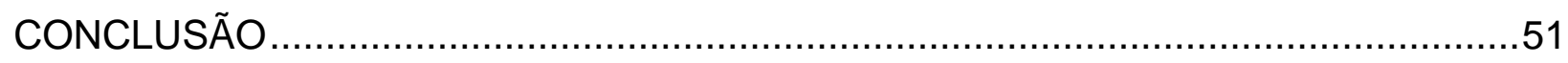

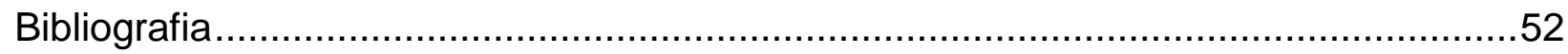

Artigo II: A macrossecuritização da Guerra ao Terror nos discursos de Brasil,

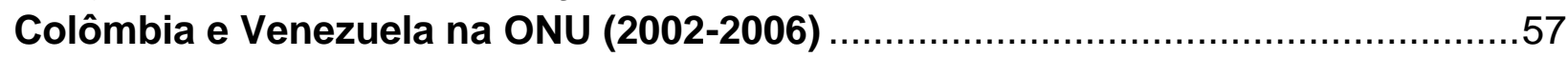

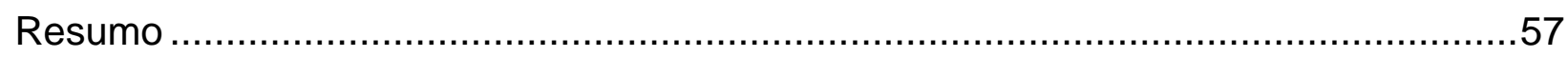

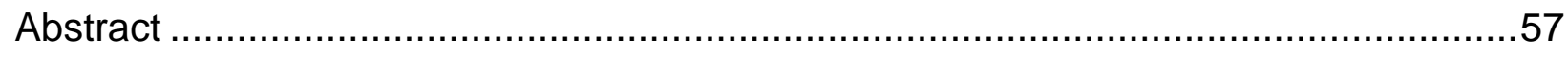

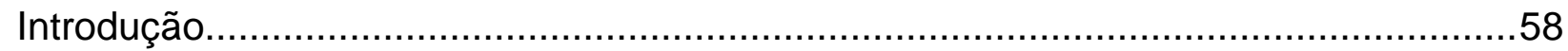

1. Justificativa da amostra e procedimentos de análise ............................................60

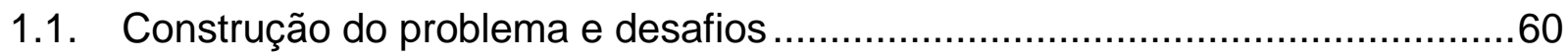

1.2 Escolha da amostra: os discursos dos presidentes de Brasil, Colômbia e

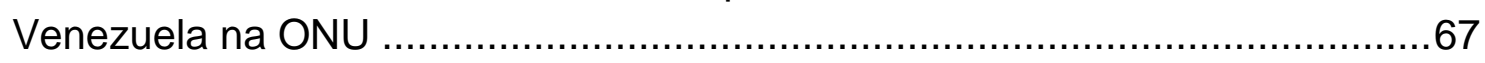

1.3. Fenômenos de linguagem analisados ........................................................69

2. A Guerra Global ao Terrorismo: formulação argumentativa e diálogo com a

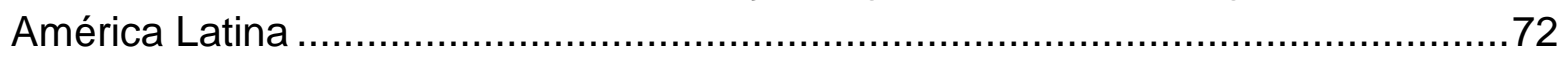

2.1. A Doutrina Bush: o marco teórico da Guerra ao Terror ................................73

3. O Terrorismo nos discursos sul-americanos na ONU: estudo de caso....................76

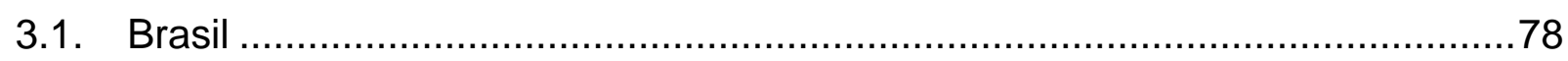

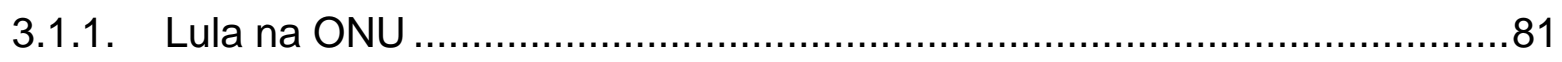

3.1.2. Linha argumentativa adotada nos discursos de Lula no Plenário da AGNU (2003-2006). 


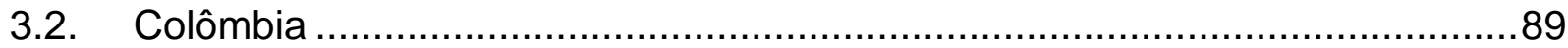

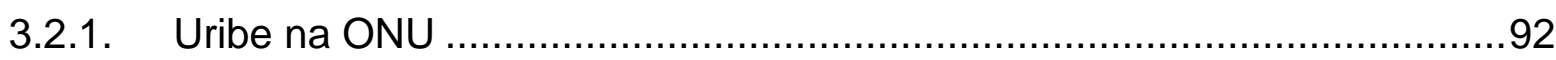

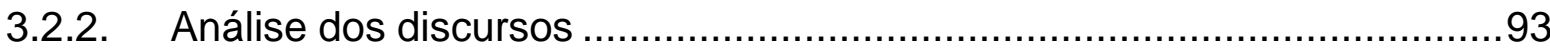

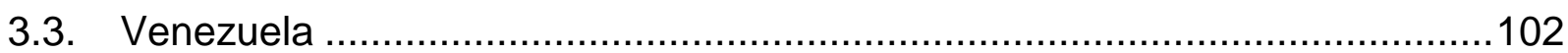

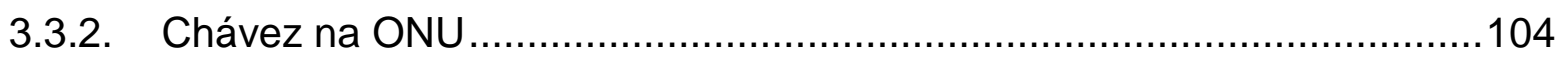

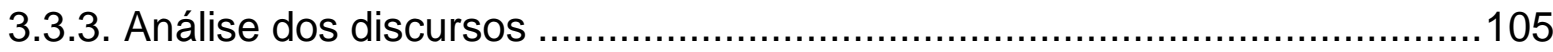

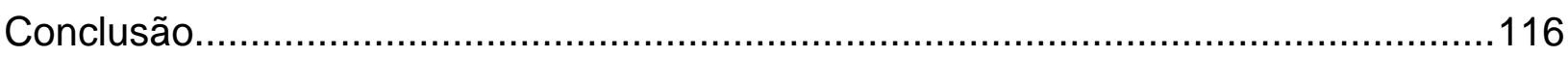

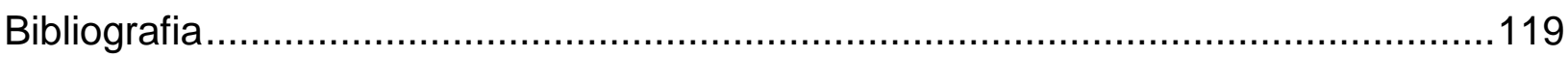




\section{Artigo I: A Análise do Discurso nos Estudos de Segurança Internacional: uma perspectiva teórica.}

\section{Resumo}

Este artigo justifica o objeto dessa pesquisa argumenta por maior adesão aos métodos linguísticos-discursivos na compreensão de fenômenos políticos. Para tal, discute-se a incorporação dos estudos do discurso na teoria das Relações Internacionais, ressaltando-se os avanços e limitações dessas abordagens. Conclui-se que a Análise Crítica do Discurso complementa a teoria da Escola de Copenhague e fornece consistentes bases para análises no campo da Segurança Internacional, como a apresentada no segundo artigo.

\section{Abstract}

This paper presents the justification of the object of this research, arguing for greater adherence to the linguistic - discursive methods in understanding political phenomena. To this end, we discuss the incorporation of discourse studies in the theory of International Relations, stressing the advances and limitations of these approaches. We conclude that the Critical Discourse Analysis complements the theory of the Copenhagen School and provides a consistent basis for analysis in the field of international security, as presented in the second article. 


\section{Introdução}

Esta pesquisa de Mestrado, que consiste em dois artigos distintos, busca identificar nos discursos oficiais de três países sul-americanos - Brasil, Colômbia e Venezuela - as articulações da temática do terrorismo, a fim de averiguar em que medida elas dialogam com a Doutrina de Segurança Nacional dos Estados Unidos da América 2002 (National Strategy Security, daqui em diante NSS 2002), também conhecida como Doutrina Bush, pela qual se consagrou a chamada "Guerra Global ao Terror" (Global War on Terrorism, GWoT ${ }^{1}$ ). Ao final, pretende-se mapear os processos de securitização da ameaça terrorista no nível discursivo, já que este seria o primeiro momento para uma suposta macrossecuritização da GWoT na América do Sul (BUZAN \& WAEVER, 2008) Tal análise se justifica porque, aceitando-se que uma ameaça de segurança é concebida e definida, primeiramente, por meio de um ato de fala (BUZAN \& WAEVER,1997), a análise dos discursos fornece rico material para que se compreenda a "neutralização" de conceitos que estão na base das ações adotas no nível político e que, em última instância, influenciam as relações de amizade/inimizade entre os atores.

Com esse fim, neste primeiro artigo, pretende-se (1) situar os estudos do discurso na discussão teórica das Relações Internacionais (daqui em diante, RI), em especial, nos estudos de segurança internacional; (2) discorrer sobre a teoria das securitizações e macrossecuritizações da Escola de Copenhague e sua intrínseca relação com o discurso; e, finalmente, (3) apresentar a Teoria dos Atos de Fala e o instrumental metodológico da Análise Crítica do Discurso, que será aplicado na análise dos discursos, a ser realizada no segundo artigo. Tal esforço justifica-se diante da natureza multidisciplinar desta pesquisa, que parte de aspectos linguísticos e cognitivos para analisar fenômenos políticos, tendo como base a teoria das securitizações da Escola de Copenhague. A delimitação dos conceitos e métodos que serão aplicados no próximo artigo é fundamental, uma vez que, se por um lado os estudos do discurso foram amplamente disseminados nas RI nas duas últimas décadas, por outro o esvaziamento da discussão metodológica expõe fragilidades dessas análises.

\footnotetext{
${ }^{1}$ As referências a Doutrina de Segurança Nacional (NSSA 2002) e Guerra Global ao Terror (GWoT) serão expressas em inglês, em função da consagração dessas siglas na literatura referente ao tema.
} 


\section{A Análise do Discurso nas Relações Internacionais: da anarquia à desconstrução}

A seguir, apresenta-se breve revisão das principais teorias das Relações Internacionais, para salientar a importância da inclusão de novos objetos de análise e de novas perspectivas ontológicas ao campo, que por sua vez sua permitiram a assimilação de outras áreas de conhecimento - como a Linguística - nas RI. Posteriormente, apresentam-se alguns dos principais trabalhos voltados a análise do discurso, com foco especial nos estudos de segurança internacional. Esse percurso é necessário por dois principais fatores: a importância de elementos positivistas e póspositivistas para a Escola de Copenhague, marco teórico desta pesquisa; as críticas que os estudos voltados ao discurso receberam dos teóricos tradicionais, principalmente na área de segurança, que questionam a validade das análises. Ao apresentar as teorias tradicionais e retraçar o caminho pelo qual se expandiram as fronteiras teóricas da disciplina, busca-se, ao final, oferecer síntese dos principais argumentos dessas correntes que justifiquem a escolha da Escola de Copenhague, complementando-a com elementos da Análise Crítica do Discurso.

\subsection{Realismo e Liberalismo: o debate positivista.}

O estudo das Relações Internacionais como área autônoma de conhecimento estruturou-se ao longo do século XX, com o intuito de explicar e antever os resultados das interações entre Estados - no sentido Westfaliano, entendidos como unidades soberanas, politicamente constituídas - no plano internacional (GIDDENS, 1987; MILLER, 1990; NYE, 2008). A partir da analogia entre o Estado anárquico e os indivíduos que o constituíam, em momento anterior ao estabelecimento da sociedade civil, chamado "Estado de Natureza" - cuja principal característica é a anarquia -, a discussão teórica estabeleceu-se em torno da premissa de que a inexistência de poder supranacional, no plano externo, imputaria às relações internacionais, condição de perpétua anarquia. Com base na percepção e observação de tal predeterminada realidade, os primeiros teóricos da disciplina, notadamente os realistas e os liberais, 
empenharam-se em identificar os padrões de comportamentos das unidades soberanas (os Estados), com base nos quais seria possível antever as consequências da anarquia.

Até meados dos anos 1980, a predominância dessas escolas, cujas perspectivas ontológicas alicerçaram-se no racionalismo e no materialismo histórico, balizou as discussões, de sem que se cogitasse incorporar os estudos do discurso nas análises dos eventos políticos. Os questionamentos da neutralidade da linguagem nas construções de cenários e na compreensão dos fenômenos internacionais só apareceram no final da década, pela crítica que as novas correntes de pensamento dirigiram às teses "racionalistas" (de realistas e liberais), que ignoravam os aspectos sociais na discussão teórica e na construção dos objetos de análise (ADLER, 1999).

A Escola Realista ${ }^{2}$, considerada a primeira grande vertente teórica das $\mathrm{RI}^{3}$, desenvolveu-se em torno da concepção de que a consequência da anarquia do plano externo seria, necessariamente, a guerra. Com base nos trabalhos de E. H. Carr e de Hanz Morgenthau, ambos publicados no imediato pós-segunda guerra mundial, 0 Realismo se estabeleceu para oferecer análise objetiva e amoral das interações entre os Estados e, em especial, da guerra. Ao desenvolverem a metáfora de Estado de Natureza Hobbesiano, no qual os indivíduos - naturalmente egoístas e violentos estariam em constante guerra entre si, os realistas concluem que os Estados, assim como os homens, estariam predeterminados a lutar pela a autopreservação (self-help), que se manifestaria nas políticas de poder (militar) de cada uma dessas unidades, igualmente soberanas, que, por interesses diversos, mas voltados aos mesmos fins (sobrevivência), impeliria ao uso da violência. A impossibilidade de se estabelecer um poder supranacional entre eles, imprimiria ao ambiente anárquico das $\mathrm{RI}$ a situação de conflito permanente. Nas palavras de Waltz, "among men as among states, anarchy or the absence of government, is associated with the occurrence of violence" (1979 p. 102.)

A corrida armamentista e a divisão bipolar do mundo nos anos da Guerra Fria contribuíram para a consagração das teses realistas, sofisticadas nos final dos anos

\footnotetext{
${ }^{2}$ Por razões de concisão, este trabalho não explicita as diferenças entre as versões clássicas e as correntes "neo", de ambas as escolas, o Realismo e o Liberalismo. Para a distinção entre o debate sobre Realismo e Liberalismo, em suas versões clássica (esta também conhecida como primeiro debate) e a do chamado primeiro debate das RI, e o debate neo-neo, ver BALDWIN, MILNER, GRIECO, LIPSON.

3 Embora os "Idealistas", - grupo de historiadores que escreveram ao final da Primeira Guerra Mundial e objetivavam a "Paz Perpétua" de Kant - sejam considerados os precursores da disciplina, moralmente objetivavam terminar a Guerra e não estruturar nenhum aparato metodológico como o fizeram os realistas, apresentados aqui como os primeiros teóricos de facto das RI (BURCHILL, 2001).
} 
1970. Na obra Teoria das Relações Internacionais. Waltz apresentou revisão do "realismo clássico", incorporando a ele os conceitos de estrutura e níveis de análise (sendo eles o individual, o estatal e o sistêmico) para compreender o sistema internacional. Ao condicionar à estrutura a predisposição para o conflito, Waltz tirou o foco da "natureza humana", ou seja, do indivíduo, como causa-motor para a guerra, chamando atenção para as desigualdades materiais entre Estados, embora reconhecesse a igualdade teórica dos entes soberanos.

\begin{abstract}
"Self help is necessarily the principle of action in an anarchic order (...) where risks of war are high (...). Nationally, the force of a government is exercised in the name of right and justice. Internationally, the force of a state is employed for the sake of its own protection and advantage. Wars among stats cannot settle questions of authority and right. They can only determine the allocation of gains and losses among contenders and settle for a time the question of who is stronger.

Nationally, relations of authority are established. Internationally, only relations of strength result short of a drive toward world hegemony, the private use of force does not threaten the system of international politics, only some of its members." (WALTZ, 1979 p.112.)
\end{abstract}

Com a incorporação dos níveis de análise, Waltz concluiu que as escolhas dos Estados no sistema internacional eram condicionadas a eventos externos, porque a estrutura internacional resultaria da combinação de dois elementos constantes, a igualdade funcional dos Estados e a natureza da anarquia, adicionados a um terceiro, de natureza variável: a distribuição do poder, fator de ordem objetiva (algo que, segundo Waltz, não seria igualitário, tampouco invariável), o que obrigaria os Estados a considerar a estrutura na tomada de decisão. A opção por conflito ou não-conflito seria exógena às soberanias, já que a estrutura, o locus de distribuição do poder internacional, imporia restrições à atuação dos Estados no nível sistêmico. Assim, o poder de cada ator estaria condicionado aos poderes dos demais, manifestados em suas capacidades militares, que permitiriam ou limitariam a ação de cada um deles dentro da estrutura. A estrutura agregaria nova dimensão, relacional e comparativa, para distribuição do poder no plano externo, no nível sistêmico, já que a liberdade de ação dos atores estaria condicionada à percepção da capacidade de poder em comparação com os demais atores.

É justamente na concepção de anarquia e conflito que se concentram as críticas da escola liberalista, para a qual a natureza anárquica do plano externo seria um dado contornável pela vontade dos atores (BALDWIN,1993). Dessa forma, Keohane e Nye (1977) aprofundam, na Teoria da Interdependência Complexa, sua teoria da 
interdependência, adicionando o caráter complexo dessas relações, que seria a chave para a cooperação no plano internacional. Para eles, os Estados poderiam alcançar estabilidade na anarquia por outros meios que não a força: a interdependência, principalmente relacionada a aspectos econômicos.

Para a vertente liberal, os agentes seriam capazes de atenuar os efeitos nocivos da ausência de governo por meio da cooperação, embora não houvesse poder supranacional que regulasse as relações entre as unidades. Os Estados, conscientes dos custos morais e dos prejuízos financeiros da guerra, optariam pela criação de sistemas de governança sem governo. Nota-se que a cooperação proposta pelos liberais é positiva e ativa, isto é, os Estados, ao proceder à escolha - racional e consciente - de cooperar, criariam instituições para permitir que essas interações se realizassem. Uma vez criadas, as instituições seriam capazes de alterar as dinâmicas das RI, já que passariam a agir independentemente dos Estados (KEOHANE e NYE, 1977).

Os liberais também questionaram a natureza "unitária" dos Estados das teses realistas, ao reconhecer o papel das instituições na manutenção da estabilidade das relações entre distintos atores, tanto no nível interno - em que instituições permitem a criação do governo -, quanto no externo - onde se verificaria governança, sem poder superior às unidades. A partir daí o liberalismo incorpora à análise novos atores - como as organizações Internacionais, as corporações multinacionais, as ONG e a sociedade civil global - que seriam capazes de influenciar no emaranhado de relações e de interfaces entre Estados e atores não-estatais. O contato entre esses diversos atores permitiria que se criasse relação de interdependência que, por sua vez, levaria a jogos de soma positiva e a estabilidade no Sistema Internacional.

Apesar das diferenças apresentadas, não se pode dizer que Realismo e Liberalismo sejam escolas diametralmente opostas (BALDWIN, 1993). Em suma, embora tenham chegado a conclusões diferentes, realistas e liberais fundamentaram suas análises sobre as mesmas premissas ontológicas, de que as estruturas imporiam desafios aos atores. A estrutura seria consequência direta da anarquia, sendo ambas um dado a priori, ao qual os Estados, atores racionais, precisariam encontrar meios para se adaptar. Para essas correntes positivistas, a língua e a Análise do Discurso não eram objetos de análise. Assim, é possível afirmar que, embora não tenham explicitado o papel da linguagem em suas teses, esses autores consideravam a língua como dado preexistente, neutro e constituído na realidade, ponto de vista que deu 
origem às diversas críticas que alguns autores, interessados em explicitar o caráter social da realidade, construída pela linguagem (HOPF, 1998; MESSARI e NOGUEIRA, 2005), destinaram às abordagens tradicionais.

\title{
1.2. Pós-positivismo: do construtivismo à desconstrução
}

\begin{abstract}
"In the field of international relations (IR), post-positivism can be credited for bringing the issue language and the use of linguistic practices to the forefront of the discipline (...). These linguistic turn influenced several critical and theoretical tendencies within the post-positivist movement, among which were constructivism and poststructuralism, which had already made an impact on humanistic fields (literature, cultural studies, art, architecture) and other social sciences (sociology philosophy religion of the studies) in the 1970s. But for IR it took the publication of several key books in 1989 for Constructivism in the terrorism finally can't recognise more of social political and cultural enquiry." (DEBRIX: 2003, p. ix)
\end{abstract}

O ambiente de transformação do final dos 1980 foi acompanhado de profundos questionamentos sobre a validade dos modelos teóricos positivistas adotados no estudo das Relações Internacionais. A queda do muro de Berlim e o fim da Guerra Fria expuseram a incapacidade tanto das abordagens realistas quanto das abordagens liberais de compreender as mudanças que levaram à extinção do mundo bipolar. $A$ globalização, a evolução dos meios de comunicação, a internet, o intercâmbio cultural propiciaram a disseminação de novos enfoques nos estudos das Ciências Sociais entre os teóricos das RI, que incorporaram a suas análises, gradualmente, elementos da Sociologia, da Linguística, da Filosofia. A adoção de novos paradigmas possibilitou que se diversificassem as perspectivas ontológicas e epistemológicas na área. $\mathrm{O}$ diálogo com as obras de Ludwig Wittgenstein, Michel Foucault, Jürgen Habbermas, Anthony Giddens e Jacks Derrida, por exemplo, lançou luz ao caráter social e subjetivo das interações humanas, rompendo-se, assim, a ideia de neutralidade das teorias racionais. A expansão das fronteiras intelectuais no estudo da disciplina foi registrada por Robert Keohane: em seu discurso na ISA, em 1989, sintetizou a discussão entre as abordagens racionalistas e as novas perspectivas "pluralistas", que mais tarde se chamaram pós-positivistas.

Inúmeros foram os caminhos percorridos pela teoria de RI nos 1990, resultando em diversas correntes teóricas, como o Construtivismo, a Teoria Crítica e o Pós- 
Estruturalismo. A seguir, expõem-se algumas das premissas do Construtivismo, que, em grande medida, são compartilhadas pelas outras escolas. Posteriormente, discutese a incorporação da Análise do Discurso nas teorias de RI pela exposição das obras consideradas "seminais" (DEBRIX, 2003), a "Virada Linguística" na área. Pelos trabalhos daqueles autores, apresentam-se também as premissas que distinguem a Teoria Crítica e a Pós-estruturalista do Construtivismo. Finalmente, realiza-se breve revisão da bibliografia dos estudos na área de Segurança Internacional com foco no discurso.

O grupo de intelectuais cujo recorte teórico ressalta o papel central dos indivíduos na construção das realidades, questionando-se assim a superioridade da razão como causa motora das ações humanas, chamou-se Construtivistas ${ }^{4}$. 0 Construtivismo, longe de ser escola homogênea, é, essencialmente, perspectiva ontológica alternativa ao Racionalismo e contemplada por autores que compartilham premissas: entre elas, a oposição à concepção de "mundo" e de "realidade" como dados a priori, externos aos indivíduos. A novidade trazida à discussão por essa vertente foi o reconhecimento de que a "realidade" é socialmente construída, fruto da percepção do sujeito, que confere significados a ela. Como consequência, não se poderia afirmar a existência de uma "razão de Estado", predeterminada, com interesses intrínsecos a ela. Ao contrário, os construtivistas observaram que, social e historicamente, agentes constroem seus interesses e preferências, em constante diálogo com os interesses e preferências de outros atores.

\begin{abstract}
"Construtivism is characterised by an emphasis on the importance of normality as well as materiel structures on the role of identity in shaping political action, and on the mutually constitutive relationship between agents and structure." (REUS-SMIT: 2011, p. 209)
\end{abstract}

No que se refere à Estrutura Internacional, os construtivistas afirmam a natureza social desse modelo, negando o argumento racionalista de que a estrutura precederia 0 agente, embora não desconsiderem que a estrutura exista (posição contestada por alguns teóricos da Teoria Crítica e pelos Pós-estruturalistas, que rejeitam a noção de estrutura). Se para os racionalistas a estrutura é de ordem material, objetiva - a

\footnotetext{
${ }^{4}$ A diversidade de abordagens surgidas nos anos 1990 e a grande discussão sobre a denominação das escolas pós-positivistas permitem que autores como Phillips e Jørgensen (2002) considerem o Construtivismo como o grande "guarda-chuva" para classificar autores que partem de perspectiva de construção social da realidade, incluindo nela a Teoria Crítica e o Pós-positivismo como subgrupos.
} 
quantidade de poder de um ator pode ser medida materialmente, por meio de armamentos e exércitos, por exemplo -, para os construtivistas, a estrutura não é externa e não independe dos sujeitos, que a constroem e a interpretam socialmente. Para esta vertente, são os significados - ideias, normas, valores, conhecimentos dos atores - que constituem a essência da estrutura, que é de ordem cognitiva.

Sob essa óptica, a anarquia não é tida como condição intrínseca das relações internacionais, cujo resultado seria ou conflito ou cooperação. Ao contrário, a anarquia é interpretada como a resultante do processo endógeno de co-construção e negociação, a partir da interação entre agentes e estruturas. Socialmente, por meio da linguagem e de práticas sociais, os atores expressam comportamentos que consideram adequados, que por sua vez são codificados em normas. À anarquia, afirmam esses autores, não se pode atribuir consequência única, mutualmente excludente (guerra ou paz), já que existiriam múltiplas possibilidades e resultados para a situação de anarquia (WENDT, 1989; ONUF, 1989).

Ao salientar o papel da linguagem na construção e na interpretação dessas várias "anarquias", Nicholas Onuf, na obra Worlds of our making (1989), ficou conhecido como o expoente da "Virada Linguística" das RI: afirma que a incorporação dos estudos do discurso é fundamental para a análise nas RI, ao mesmo tempo em que rejeita a possibilidade de produção de "conhecimento científico" nas Ciências Sociais. Para o autor, não haveria "métodos científicos neutros" na produção do conhecimento, pois eles mesmos são produtos sociais. Dessa forma, sugere que os analistas se voltem para o discurso, por entender que este precederia a ação dos atores, já que ao discursar os indivíduos estariam, também, agindo.

No primeiro momento, a "Virada Linguística" nas RI esteve associada à rejeição das premissas adotadas pelas Escolas anteriores, essencialmente pautadas no caráter representacionista da linguagem (já que, como dito acima, o discurso não é visto como variável importante). O foco nos processos pelos quais os atores tentam negociar e/ou moldar a realidade pelos jogos de linguagem, de acordo com seus próprios interesses e preferências, incorpora, também, a perspectiva de mudança ao cenário internacional. As regras serviriam para informar os agentes: orientariam os agentes em suas escolhas, na mediação entre agentes. A centralidade no discurso se justifica porque é pelo discurso que se constrói a realidade, por meio de regras "naturalizadas". Dessa forma, seria pelo discurso que se alcançariam mudanças na realidade, ou nas normas naturalizadas entendidas como realidade, e que se poderia alcançar a mudança nas RI. 
Ao propor que o plano internacional, assim como as sociedades, seja dinâmico, Onuf rejeita a rigidez da anarquia, que ele substitui pelo conceito de heteronomia. Sob essa condição, a relação entre os agentes seria intermediada por normas de conduta que serviriam para legitimar determinadas ações/comportamentos. Fazendo uma releitura da Teoria dos Atos de Fala, proposta por Austin e desenvolvida por Searle ${ }^{5}$, Onuf identifica, na linguagem performativa, a origem das regras que prescrevem determinadas condutas (ilocução) internacionais, que, uma vez aceitas pelos atores (perlocução), são reproduzidas e neutralizadas como dados da realidade. Dessa forma, o autor utiliza três dos cinco "atos de fala" propostos por Searle, para diferenciar três tipos de normas de governança no plano externo, que por sua vez atribuiriam três diferentes características à anarquia ${ }^{6}$. Os atos de fala diretivos, afirmou Onuf, dariam origem a normas que permitiriam relações de Hegemonia. Aos atos hierárquicos, ele associou as normas que propiciariam a Hierarquia dos atores no plano internacional. Aos atos de fala compromissivos, ele identificou normas que dariam origem à condição de Heteronomia.

A manutenção de determinado status quo ou cultura de hierarquia dependeria, então, da adesão dos atores às regras, enunciadas pelos atos de fala. Ao colocar o "ato de fala" ${ }^{7}$ como central na produção das normas, Onuf rompeu com a noção de interesse nacional e de "razão de estado", entendidos como necessidades naturais e imutáveis, aos moldes de Richelieu (MILLER, 1990). Pelos atos de fala, os atores constituiriam as regras, que depois de institucionalizadas seriam "naturalizadas", teriam efeitos distributivos na sociedade, assegurando privilégios a uns e impondo restrições a outros. Apesar da importância atribuída aos atos de fala em seus trabalhos, Onuf não desenvolve a maneira como deveriam ser estudados, tampouco explicita o processo que leva um ato de fala a ser codificado em norma. Além disso, embora sua teoria dos atos de fala resida na tradição pragmática anglo-saxã, e apesar do reconhecimento da importância dos Jogos de Linguagem propostos por Wittgenstein, a concepção de linguagem de Onuf aponta para os trabalhos de Jacques Derrida, fundador do movimento de desconstrução.

\footnotetext{
${ }^{5}$ A obra desses autores será exposta de maneira pormenorizada adiante.

${ }^{6}$ No tópico em que se discutirá a metodologia, a Teoria dos Atos de Fala será apresentada em pormenores.

Ole Waever também pode ser mencionado como um autor construtivista que baseou sua teoria nos Atos de Fala. As premissas de Waever serão apresentadas no tópico em que se estuda a Escola de Copenhague.
} 
Trazido à discussão das RI pela obra de Der Defina e M. J. Shapiro, InternationallIntertextual Relations: Postmodern Readings of World Politics, também publicada em 1989, o conceito da Desconstrução ${ }^{8}$, proposto por Derrida, balizou diversos estudos voltados para o discurso na área (Ashley e Weber, 1990; Dotty, 1993; Campbell, 1997), no âmbito do movimento que ficou conhecido como pós-estruturalista. Para o pai da desconstrução, seria impossível afirmar a existência de um mundo "real", que prescindisse da interpretação humana (Derrida, 1988). Em outras palavras, o mundo como o vemos se pode compreender somente por meio da linguagem, que precederia à definição do objeto, conforme as definições de Saussure (por exemplo, uma cadeira é uma cadeira somente porque eu a chamo cadeira; não haveria identidade "natural" entre aquilo que denominamos cadeira e o objeto que ela representa), distanciando-se dele o autor ao afirmar que este processo não é neutro. Para explicitar o caráter linguístico da interpretação do "real", o movimento de desconstrução seria forma de desestabilizar conceitos dados como "estáveis", confrontando-os com as oposições a que remetem. O intuito de Derrida era demonstrar as consequências das oposições estabelecidas pela linguagem, já que, para ele, as oposições entre conceitos estabeleceriam padrão hierárquico, em que um dos conceitos seria privilegiado em detrimento do outro.

Para identificar e desestabilizar "conceitos dominantes", tidos como estáveis e naturais, Derrida propõe, então, duas leituras nas análises de texto. Em uma delas, o leitor aceitaria a interpretação e os pressupostos dominantes, abraçando a "estabilidade" dos conceitos; essa leitura serviria para indicar a coerência dos argumentos e a linha de raciocínio da interpretação que se privilegia. Na segunda leitura, no entanto, os pressupostos da primeira leitura deveriam ser rejeitados, invertendo-se os argumentos, de forma a explicitar as incoerências da leitura anterior. O foco dessa análise é não a busca da verdade ou falsidade dos argumentos do texto, mas, sim, a exposição das tensões intrínsecas a cada narrativa: a intenção inicial seria justamente forjar homogeneidade e continuidade que permitissem a valoração de dada interpretação (DEVETAK, in BURCHILL et alii, 2001). Finalmente, seria necessário desconstruir os discursos para que, ao remontá-los, se compreendesse como se atingiu determinado resultado (ou interpretação).

\footnotetext{
${ }^{8}$ Embora muitos autores considerem a desconstrução um "método", em Carta a um amigo japonês Derrida (1983) afirma que o que propõe como desconstrução "não é um método e nunca poderia ser visto como tal". Disponível em:

http://www.egs.edu/faculty/jacques-derrida/articles/letter-to-a-japanese-friend/ (último acesso 10/05/15)
} 
O rompimento da visão representacionista da linguagem e a adesão ao movimento de desconstrução estão no cerne dos trabalhos de Laclau e Mouffe, cujas premissas foram amplamente incorporadas nos trabalhos de RI voltados para a Análise do Discurso posterior à década de 1990 (Esptein, 2008; Torfing, 2005; BARROS e CASTAGNOLA, 2000; HANSEN 2006). Em sua obra seminal, Hegemonia e Estratégia Socialista (1985), os Laclau e Mouffe afirmam que seria necessário restabelecer os princípios do Marxismo clássico, no intuito de chegar a um marxismo radicalmente democrático e inclusivo. Com esse fim, aplicaram os métodos de desconstrução de Derrida para questionar a noção de superestrutura e a de luta de classes. Influenciados por Althusser e por Foucault (na definição social do discurso), por Lacan (na Psicologia), pelo Estruturalismo semiótico de Saussure, e pelo conceito de hegemonia de Gramsci, os autores questionam o essencialismo das teorias marxistas, afirmando que as noções de estrutura, de supraestrutura e de luta de classes são, na verdade, construções discursivas. Não haveria realidade objetiva além da linguagem, e, por isso, os autores negam que os fatores socioeconômicos (os fatores de "base" do Marxismo) tenham importância por si mesmos, independentemente da linguagem. Como explicam Joergensen e Phillips (2002, p. 27), "nenhum objeto tem significado a priori" e "a construção dos sentidos depende da constituição de um campo discursivo".

Para analisar os discursos, responsáveis pela representação da realidade, esses autores propõem os conceitos de "significante flutuantes" e de "desestabilização do campo simbólico". Admitido o pressuposto de que todo discurso é ideológico, Laclau e Mouffe procuram entender o processo de fixação de significados no interior dos discursos, que estaria articulado em torno de pontos nodais (1985 p. 105). Por "significados flutuantes" se referem aos diferentes significados a que um termo pode remeter, dependendo de como ele é articulado no texto. Disso decorre a afirmação de que a linguagem não poderia corresponder a objetos reais nem representá-los, já que é sempre simbólica e metafórica, e por ela os falantes buscam, contínua e infinitamente, fixar significados. Assim, os autores chegam à conclusão de que o discurso seja redutor de possibilidades. Dessa forma, lançam luz às contradições inerentes ao discurso, principalmente o discurso político, que busca conciliar conceitos antagônicos e identidades multifacetadas em um mesmo texto, de forma a privilegiar determinada visão de mundo e uma identidade que se constrói nesse discurso.

A diferença entre "eu" e o "outro", o "cidadão" e o "estrangeiro" são dicotomias que os autores da Teoria Crítica buscam eliminar, preconizando a produção engajada 
do conhecimento (VILLA, 2008). Para os membros dessa vertente, o conhecimento sempre tem fins políticos, o que o tornaria capaz de ensejar transformações na realidade. Em diálogo direto com Kant, com Marx e com Habbermas, a Teoria Crítica propõe que a produção do conhecimento tenha como fim principal a emancipação. Para esses autores, a produção teórica deveria ser normativa, do "dever ser", uma proposta de transformação que visasse ao bem-estar da humanidade como um todo.

Um dos principais expoentes da escola, Andrew Linklater, alicerçando-se na obra de Immanuel Kant, busca reafirmar os princípios éticos que levassem em conta a humanidade como um todo. Para isso, propõe moralidade reflexiva, que estivesse além das fronteiras nacionais, em que múltiplas identidades se respeitassem, sustentadas em princípios éticos.

\footnotetext{
"Whether within states or in the relations between them, the same issue therefore arises: how to promote universality which respects difference, and how to give public expression to cultural differences without encouraging and unleashing extreme particularism." (LINKLATER: 1998 p.27)"
}

Para alcançar esse fim, no entanto, seria necessário um projeto de ética cosmopolita. Aqui, Linklater propõe que haja não "hierarquia moral", mas, sim, o entendimento das partes por meio de diálogos éticos, retomando a ideia de discursos éticos propostos por Junger Habbermas. Os discursos éticos seriam baseados na comunicação inteligível, a todos os atores, das crenças e das ações do sujeito, de forma que pudessem ser aceitas ou contestadas. Da mesma forma, no plano externo, instituições e normas deveriam estar sujeitas ao escrutínio coletivo (ou seja, todas as partes afetadas por esse discurso, sejam elas Estados ou não), para que pudessem ser legítimas. Para alcançar esse consenso, o discurso dos atores deveria ser ético, isto é, não-excludente, democrático, a servir como forma de ponderação moral para os temas tratados (DEVETAK, in BURCHILL et alii: 2001, p. 175). Ao se adotar a ética no discurso, seria possível modificar o contexto estrutural no qual as relações internacionais se construíram (LYNCH, 2000, apud DEVETAK, 2001). Assim, seria possível também resolver conflitos e questões de violência nas Relações Internacionais pelo diálogo ético, que, ao contrário das "negociações", eliminaria a ideia de adversidade entre o "eu" e o "tu", substituindo-a por "nós" (HOFFMAN, 1992). 


\title{
1.3. Análise do Discurso em Segurança Internacional
}

A análise do discurso para explicitar a importância da linguagem na construção de identidade e de diferença orientou, também, os estudos voltados para a área de segurança ${ }^{9}$. A forma como os estudos de Segurança foram conduzidos registrou mudanças estruturais desde 1945. Antes voltados esses estudos para as questões estratégicas que envolviam a rivalidade das superpotências e armas nucleares, nos dias atuais novos temas passaram ocupar o mesmo patamar dos problemas militares, conferindo à área abordagens com largo espectro, que vai desde o Realismo até o Feminismo e o Pós-colonialismo (BUZAN e HANZEN, 2011).

\begin{abstract}
"Discourses of war conflict and National Security have been the subject of studies by a number of critical and feminist IR thinkers in the past two decades (Elshtain 1987; Hess and Faree 1987; Enloe 1990; Elshtain and Tobias 1990; Campbell and Dillon 1993; Jabri 1996; Katzenstein 1996; Gray 1997; Campbell 1998). Since IR itself is often said to be the offspring of the state of war such critiques raise crucial questions about the academic practice of IR. Is IR reproducing meaningful insight or 'knowledge' about its subject matter? Is it simply attempting to impose an intellectual order on an extraordinarily complex and dynamic social reality through the repetition of its own self-referential narratives about corporate violence? Are IR narratives of war little more than the production and reproduction of existing power structures (states the presumed hierarchical relations among states, the imaginary totalities of IR theoretical narratives) through linguistic practices that invent networks of categories, totalities, terminologies and meanings?" (WILMER in DEBRIX: 2003, p. 225)
\end{abstract}

Enquanto os primeiros trabalhos do discurso nas $\mathrm{RI}$ se voltaram para a análise da anarquia e para a crítica ao Positivismo, David Campbell recorreu à linguagem para analisar temas de segurança e de identidade. Em Writing Security (1993), o autor examina a maneira como o discurso de segurança na política externa norte-americana durante a Guerra Fria se voltou para dicotomias como interno/externo, eu/outro, dentro/fora para "domesticar" desafios que conviessem à identidade dominante. Conclui que a percepção da ameaça se constituía no discurso que refletia o papel subjetivo da segurança e a neutralização de interpretações enviesadas.

Com base no conceito kantiano de "risco", que estaria intrinsecamente atrelado a quem interpreta os riscos, o autor conclui que a noção de perigo não é condição

\footnotetext{
${ }^{9}$ A Escola de Copenhague é uma das principais vertentes de análise de segurança com bases discursivas. Por ser o marco teórico deste trabalho, ela será analisada em item separado, apresentado adiante.
} 
objetiva, ressaltando o processo de interpretação do risco para a cristalização de determinadas formas de representação em relação aos referentes apontados como "perigosos". Afirma que a habilidade de apresentar certos referentes como externos, subversivos, doentios ou imorais foi seminal para a articulação da noção de perigo na política externa norte-americana, destarte desnaturalizando determinadas identidades para resguardar a "identidade verdadeira", que, por sua vez, possibilitaria a adoção de determinadas políticas, sem que houvesse resistência, pela alegação de que a "única e verdadeira" identidade estaria em risco. De maneira análoga, Simon Dalby, em Creating the Second War: the discourse of politics (1993), atém-se aos discursos geopolíticos para explicitar como as relações de identidade e de alteridade são construídas e atreladas ao território, sendo finalmente narradas em termos de ameaça militar (DEVETAK, in Burchill et alii: 2001, p. 194).

Assim como em Campbell, os trabalhos de segurança de viés pós-estruturalista transferem o foco de suas análises para o discurso - e não para as ideias em si, como ocorre no Construtivismo -, argumentando que os conceitos de soberania e segurança são construções do discurso (BUZAN e HANSEN, 2011, p. 35). Os autores dessa vertente alegam que não há estruturas materiais que influenciem a construção discursiva, já que elas em si são parte do discurso (SHAPIRO, 1981; DILLON, 1990). Por essa razão, veem a segurança - ou a paz - como discurso, prática na qual os sujeitos são constituídos, reconhecendo que atores e identidades não são estáveis e dados. Assim, a segurança nacional poderia ser analisada não quanto a ameaças que se impõem aos Estados, mas, sim, pelo processo pelo qual a "nação" passou a se definir e reproduzir um conceito de identidade em oposição a outras

\footnotetext{
"National security was not, in short, something that could be assessed through an analysis of which threats a nation confronted, but rather a process through which the "nation" came to be produced and reproduced with a particular identity." (BUZAN e HANSEN: 2011, p. 142)
}

A segurança, para o Pós-estruturalismo, pressupõe, então, a construção radicalmente diferenciadora e inferiorizadora do Outro, ameaçador em oposição ao "eu", que se constrói por essa oposição, já que a noção de identidade é relacional. Destarte, os discursos de segurança se constituem não exclusivamente sobre os "outros" externos, mas sobre os outros internos. Exemplos de autores que trabalham nessa temática são Walker (1990), que traçou evolução histórica de como a questão de 
soberania está conectada às concepções de segurança, dando poderosa resposta às questões de identidade política, situando-as em contexto espaço-temporal do Estado, e Dalby (1988, p. 423), que discorreu sobre a influência das ideias de estrutura nos discursos de segurança e de formações de ameaça e identidades em contexto amplo.

A análise das narrativas e dos jogos de linguagem com foco em segurança foi realizada mais em termos teóricos e hipotéticos e menos de um ponto de vista empírico no Construtivismo Crítico. Por meio de perspectiva diferente da dos pós-estruturalistas, os construtivistas críticos partiram do Estado como ator e não como sujeitos constituídos discursivamente (BUZAN e HANSEN, 2011, p.199). A identidade seria, então, algo que os Estados possuem, enquanto para os pós-estruturalistas a identidade é construída discursivamente. De certo ponto de vista construtivista, Fierke (1996) estudou a forma como as questões de identidade e de intertextualidade na prática discursiva foram fundamentais para a construção da narrativa da guerra da Bósnia, atentando para a participação da mídia ocidental no processo de naturalização de conceitos. Já Mutimer (1998) analisou como as práticas discursivas da proliferação nuclear foram reformuladas por narrativas voltadas para as armas químicas e para as armas biológicas no fim da Guerra Fria, fundamentalmente para constituir esses armamentos no "desarmamento", na "economia de mercado", na "guerra às drogas", ao invés da discussão de "proliferação", que poderia reorientar a constituição dos objetos de referência, identidades e interesses e, dessa forma, a indicação de quais políticas poderiam ser adotadas. O próprio Mutimer (1998), por exemplo, identifica as identidades nos discursos de proliferação em termos de "fornecedores" e "receptores".

Com base na teoria da Escola de Copenhague (que será discutida a seguir), Musumeci (2011) se voltou aos Livros Brancos de Defesa dos países da América do Sul para identificar os movimentos de significação relacionados às questões de segurança e defesa, combinando aspectos da pragmática anglo-saxã com a semiótica estruturalista francesa. Alicerçado nessa análise, rediscute a classificação da América do Sul como um Complexo de Segurança Nacional.

No que concerne aos estudos de segurança relacionados aos discursos sobre o terrorismo, inúmeros trabalhos foram publicados após o 11 de setembro, com ênfase na análise do discurso da Guerra ao Terror. É o caso de Erica Resende, que adota a perspectiva discursiva, com base na teoria de Connolly, Laclau e Mouffe (1985) e Jackson (2005), para explicitar o papel do discurso como construção da realidade e das relações de identidade, a fim de compreender as "condições de possibilidade" que 
propiciaram a Guerra ao Terror do pós-11 de setembro. Resende (2009) afirma que o discurso da Guerra ao Terror só foi permitido e aceito porque exterioriza determinada concepção de identidade, que reside na lógica puritana.

Jarvis (2009) também parte da teoria de Laclau e Mouffe para analisar a Guerra ao Terror, em Writing the War on Terror. Nesse trabalho, o autor procura reconstruir as articulações temporais expressas na Guerra ao Terror, que tentaram neutralizar recortes temporais contraditórios - ruptura trazida pelos ataques terroristas; linearidade dos eventos de violência terroristas de um lado e progresso e vitória da civilização norte-americana do outro; atemporalidade, na luta do bem contra o mal - na fixação dos significados aos quais a narrativa do Governo Bush remeteu, que em última instância legitimaram a empreitada militar para proteger a "identidade" norte-americana.

Jackson (2005) adota o instrumental da Análise Crítica do Discurso (que será discutida a seguir), para explicar como o discurso da Guerra ao Terror foi articulado para normalizar campanha global contra o terrorismo. Segundo o autor, seriam necessárias, muito mais do que propaganda ou diplomacia pública, a articulação e a aceitação de nova narrativa, que reconstrói o mundo e apresenta nova realidade, inquestionável e neutralizada.

\subsection{Análise do Discurso nas RI: críticas}

Como se pretendeu demonstrar acima, o estudo do discurso foi incorporado pelas diferentes escolas pós-positivistas e deu origem a diversos trabalhos de análise do discurso no âmbito das Relações Internacionais. A adoção do discurso como objeto de pesquisa, no entanto, não esteve imune às críticas, vindas não só dos racionalistas (KEOHANE, 1988; MEARSHEIMER,1994) mas também de autores pós-positivistas, como Wendt (1995, p. 72), que questionam a validade científica dessas análises.

Nas Relações Internacionais, a análise do discurso foi, primeiramente, trazida por autores que questionaram a presunção de neutralidade da linguagem, como mera denominação da realidade. Se por um lado os teóricos da Virada Linguística obtiveram grande êxito em avançar a discussão ontológica, questionaram o caráter existencialista do discurso e lançaram luz à importância da incorporação da linguística nas RI, por outro a pouca atenção dada aos métodos resultou em uma série de simplificações, 
generalizações de conceitos e fraca adesão às metodologias desenvolvidas por décadas na Linguística, o que, de fato, compromete a validade das análises.

\begin{abstract}
"Beyond this call to study the politics of representation, there has, however been, strikingly little examination of appropriate methods and criteria for discourse study. The problem is not as some critics would have it there is little or no research. Rather is that not common understanding has emerged in international relations about the best way to study discourse." (MILLIKEN: 1999, p. 226)
\end{abstract}

Após a década de 1990, os trabalhos que se voltaram para a compreensão de textos escritos nas RI foram chamados, indistintamente, "análise do discurso". Ao contrário do que se acredita, nem todo trabalho cujo foco é a linguagem pode ser chamado "Análise do Discurso", que se deve entender como método linguístico de compreensão dos significados de enunciados executados. A leitura e a interpretação de textos, quaisquer que sejam os gêneros, escritos ou orais, espontâneos ou não, sempre estiveram no cerne dos estudos das Ciências Humanas. O que distingue os trabalhos que privilegiam a análise do discurso, no entanto, é o reconhecimento do objeto discurso como foco da análise e a metodologia aplicada à interpretação dos textos. $O$ analista do discurso não se interessa apenas pelo significado imediato que se pode atribuir a determinadas sentenças. A ele, interessam os significados, os diversos movimentos cognitivos, os subentendidos, a interlocução, a polifonia, as intenções, entre outros, por trás desse complexo objeto que é o discurso. Para isso, ele utiliza uma série de conceitos e métodos que, embora não assegurem que a análise seja incontestável, permitem que se chegue a conclusões sólidas, com maior grau de objetividade. Milleken (1999, p. 227) explica como a rejeição dos métodos enfraquece a discussão:

\footnotetext{
"The inattention to the discourse research is not without its reasons. Scholars working in these areas wish to challenge the 'scientism' of mainstream International Relations it's search for scientific theory and laws, weather cast in neopositivist (inductive) or rationalist (deductive) terms and, accompanying that, its seeming obsession with methodology (Der Derian: 1989; George: 1994). However, to refuse to engage in mainstream modes of doing social science should not mean being the exclusion from debate of issues of research method. Scant attention to these leashes discoursed at this at a disadvantage within research community".
}

Com isso, não raros são os casos de trabalhos que alegam apresentar uma análise do discurso, mas que mais se aproximam do textualismo, leitura e interpretação 
de texto (GOMES, 2009). Por essa razão, acredita-se necessário que, nos trabalhos destinados à análise do discurso, explicite-se, além da teoria, o instrumental linguístico utilizado nas análises, porque pesquisas de análise do discurso que não se voltem para o complexo emaranhado de relações e de procedimentos linguísticos e cognitivos que desembocam no processo de significação correm o risco de produzir leituras de enunciados linguísticos revestidas de análise de discurso que, sem 0 rigor metodológico para diminuir os preconceitos do analista, guarda grande possibilidade de atingir conclusões que refletem aquilo que o pesquisador quer ler no texto.

Geras (1990) atenta para essa fragilidade na crítica à obra de Laclau e Mouffe. Ao rejeitarem a existência de realidade pré-discursiva e a possibilidade de objetividade extra-teórica, esses autores, argumenta Geras, seriam incapazes de construir qualquer critério de medida para qualificar a alegação que apresentam. Em última instância, ofereceriam "Discurso sobre o discurso", vácuo, tanto de um ponto de vista normativo quanto de um ponto de vista prático.

\begin{abstract}
"The arguments, in effect, denied the existence of an objective reality which render them philosophical idealists with no external control to check on the truth of relativised discourses. Geras reject the notion that the aspirations of 'cognitive objectivity' shared by Marxists and those subscribing to the Enlightenment tradition implied claims to absolute certainty. These conflated the aspiration to truth, with an attitude towards it. Such an aspiration did not imply dogmatism but always the possibility of revision in light of new information and evidence and therefore it is inherently democratic." (TOWNSHEND:2004, p. 272)
\end{abstract}

Jule Townshend (2004, p. 286) acrescenta que:

"yet, as we have seen, traditional methodology, epistemologies, 'positive' ontologies and ethical theories, including non- deterministic Marxism, cannot be abandoned out of hand, otherwise the danger is that discourse theory will follow the way all of all fads, a paradigm that implodes through its own fundamentalism."

Banta chama atenção para isso no artigo Analysing Discourse as a causal mechanism (2012: 380):

"I do this because of dissatisfaction not only with how discourse is often studied in IR, but also because of the avoidance of discourse analysis in the study of empirical puzzles which clearly involve some significant impact being attributed to a particular discourse or discourses. Of course, to the extent that every social event or act involves some level of communication, anything can be analysed for the discourses that surround and give meaning to it. To do so for most IR scholars means to adopt a 'discoursive perspective - specified by the most popular discourse-analytic sub-field in IR, poststructuralist discourse theory 
(PDT) (Torfingl: 2005: 3).Within PDT it is contended that to study discourse one most avoid any pretence to claims of having found some relatively vital causal relationship within a phenomenon, or any meaningful role for extra-discursive 'reality'.

(...)

But the nature of exisiting theoretical frameworks - where significant play is given to extra-discursive causal elements such as technology, system structure or post-industrial social conditions - means that in order to resolve disagreements by building building upon existing knowledge, a PDT perspective is inadequate."

A abordagem discursiva para a análise das securitizações proposta pela Escola de Copenhague (apresentada a seguir) oferece respostas a algumas dessas lacunas, mas, assim como as demais abordagens, não explora com profundidade o aspecto linguístico-metodológico. Para tentar suprir essa deficiência, aqui se advoga pela incorporação da Análise Crítica do Discurso como referencial metodológico nas análises. Como se verá adiante, a ACD complementa a teoria da Escola de Copenhague e oferece a ferramenta necessária para análise mais consistente dos processos de securitização no plano do discurso.

\section{Marco teórico: Escola de Copenhague}

Em seguida, apresentam-se os principais conceitos da Escola de Copenhague, que compara os processos de securitização aos "atos de fala" (Teoria das Securitizações), considera a proximidade territorial como fundamental nas dinâmicas de segurança internacional (os Complexos Regionais de Segurança) e permite que se avaliem os processos de securitização em nível sistêmico (macrossecuritização).

O intuito de estudo desta pesquisa - macrossecuritização do terrorismo como ameaça à segurança internacional - fundamenta-se na produção intelectual dos autores da Escola de Copenhague ${ }^{10}$, em especial na Teoria das Securitizações. Nesta sessão, serão apresentados os principais pressupostos dessa escola, de forma a situála na discussão teórica das Relações Internacionais, justificar a relevância do objeto

\footnotetext{
${ }^{10}$ Barry Buzan, Ole Wæver e Jaap de Wilde são considerados os fundadores da Escola de Copenhague, cujo nome remete ao Instituto de Estudos da Paz de Copenhague, criado, em 1985, pelo Parlamento Dinamarquês. Em 2003, o instituto foi incorporado ao Instituto Dinamarquês para as Relações Internacionais http://www.diis.dk/en.
} 
desta análise e evidenciar a importância da Análise do Discurso na Teoria das Securitizações.

A Escola de Copenhague pode ser classificada como essencialmente construtivista, embora aceite algumas das premissas realistas, expressas na forma como Barry Buzan e Ole Waeve se autodefinem: "construtivistas-realistas" (1997). Em termos ontológicos, mantêm-se alinhados ao construtivismo e às demais correntes póspositivistas, que explicitam o caráter social das relações Internacionais. Assim como Klein (1994) e Campbell (1993), os autores da Escola de Copenhague rejeitam a ideia de que existam temas "naturais" de segurança e salientam o papel dos agentes na construção daquilo que estes entendem por segurança - distanciando-se, assim, dos realistas, para os quais questões de segurança são intrínsecas ao sistema anárquico, cujo Estado seria único ator. Embora aceite a relevância do Estado e dos assuntos militares nas questões de segurança, a Escola de Copenhague rejeita a ideia de que a combinação soberania mais força sintetize os estudos de segurança, abrindo espaço em suas análises para novos temas e novos atores.

As divergências da Escola de Copenhague com os pós-positivistas aparecem nos resultados que a Escola pretende alcançar pela produção teórica. Em comparação com a Teoria Crítica, por exemplo, o projeto da Escola de Copenhague é bem menos ambicioso. Se por um lado os críticos, com sua análise engajada, assinalam a possiblidade de mudança da realidade social por meio do conhecimento, os autores da Escola de Copenhague não se atribuem essa tarefa de emancipação humana, embora admitam que os resultados que pretendem alcançar possam ter como complementares os alcançados pelas análises críticas. Para eles, embora seja construída socialmente, a "realidade" é, na maior parte dos casos, sedimentada e relativamente estável, o que permite ao pesquisador compreender o modus operandi das dinâmicas de segurança e fornecer explicações que relacionam causa e efeito aos conflitos. Nesse sentido, os autores da Escola de Copenhague aproximam-se dos positivistas, que adotam perspectiva teórica voltada para a solução de problemas ("problem-solving theories"). Em outras palavras, embora Buzan e Waever adiram à perspectiva filosófica "radicalmente" construtivista, os produtos de suas análises se assemelham aos das versões clássicas, porque os autores (1997, p. 35) "at its best attempted to grasp security constalations and thereby steer them into benign interactions. this stands in contrast to the "critical" purposes of CSS, which point toward a more wholesale refututation of current power wielders.". 
Para conciliar a inclusão de temas e atores "não-tradicionais" com as análises de viés positivista, esta vertente aposta na sólida definição de conceitos e de modelos de representação teóricos, a partir dos quais os autores reconstroem os processos de securitização, desde a concepção de segurança, passando-se pela construção das ameaças, pela necessidade de combater problema por medidas excepcionais, até a aceitação e a securitização da ameaça. Os autores adotam os níveis de análise (do individual ao sistêmico, dando grande relevância ao nível regional) como referentes ontológicos, ou "aparatos", e não como explicação em si mesmos, evitando-se, assim, que se assuma posição essencialmente Estado-cêntrica. A importância dos níveis, argumentam eles, é que diferentes atores, em cada um dos níveis, teriam diferentes concepções de ameaça, sendo a segmentação em níveis importante para identificar tais diferenças.

O intuito da Segurança Internacional identificado pela Escola de Copenhague é emprestado do Realismo: segurança é sobrevivência. Para a Escola, porém, segurança tem por meta a sobrevivência não apenas, mas principalmente, dos Estados. $O$ viés construtivista aparece na definição da natureza da segurança proposta pela Escola; essa vertente afirma que segurança não se equipara à força (exército): segurança é, essencialmente, processo político, intersubjetivo e relacional.

\footnotetext{
"'Security' is thus a self-referential practice, because it is in this practice that the issue becomes a security issue - not necessarily because the real existential threat exists that because the issue is presented as such a threat." (BUZAN $e$ WAEVER: 1997, p. 21)
}

O reconhecimento de "ameaça existente", para a Escola, só pode ser entendido em relação a uma característica particular do objeto de referência em questão. A questão de existência da ameaça varia de acordo com os níveis e com os setores, assim como com a natureza dessas ameaças. Por isso, o pesquisador deve, antes de aceitar uma ameaça como "dada", perguntar: quem a interpreta como tal, em relação a quem, e por quê.

"Based on a clear idea of the nature of security, securitisation studies aim to gain an increasingly precise understanding of who securitizes, on what issues (threats), for whom (referent objects) why, with what results, and, not least, under what conditions (i.e., what explains when securitization is successful)." (BUZAN et alii: 1998, p. 32) 
O processo de securitização, argumentam, tem início quando um ator, o agente securitizador, identifica um objeto e o articula como ameaça à sobrevivência de um referente. A inação diante da ameaça identificada, argumenta o agente securitizador, implica altos custos e pode levar à aniquilação do referente. Pela percepção da natureza "urgente da ameaça", esse agente clama por medidas excepcionais, que estão além das práticas políticas rotineiras. Nota-se que tal processo ocorre pela enunciação de um objeto como ameaça, ou seja, por um ato de fala.

"The process of securitisation is what in languages theory is called a speech act. It is not interesting as a sign referring to something more real; it is the utterance itself that is the act. By saying words, something is done." (Idem p. 26)

Assim como Onuf e Kratochwil, os teóricos da Escola de Copenhague atentam para a importância de analisar o discurso no estudo das Relações Internacionais, ao equiparar a linguagem à ação. A novidade trazida por Buzan e Waeve é a articulação entre o tema tradicional da segurança e o discurso, colocando $o$ ato de fala no centro da questão, porque, embora admitam que a segurança trata da sobrevivência dos atores, é pela enunciação que determinados objetos são articulados e elevados ao status de "ameaça de segurança", ou seja, ameaça de sobrevivência. A mudança fundamental está no fato de que rejeitam a ideia de que naturalmente existam objetos de segurança. Uma ameaça só ganha o status de ameaça quando um agente, no discurso, a enuncia como tal.

Decorre-se disso a afirmação de que segurança e ameaça são de natureza subjetiva e relacional. É na percepção dos atores entre si e sobre os objetos de referência que reside a ameaça. A simples enunciação (locução) de um objeto como ameaça (ilocução) não é suficiente para concluir o processo de securitização, que é a adoção de fato das medidas enunciadas no discurso (perlocução) ${ }^{11}$ : para tal, é necessário que os interlocutores desse discurso aceitem a alegação como legítima. Por

\footnotetext{
${ }^{11}$ Os atos de fala, divididos por atos locutórios, ilocutórios e perlocutórios por Austin e desenvolvidos por Searle, serão explicitados adiante, ao se tratar de metodologia. Neste ponto, é importante que se ressalve o que essa teoria diz quando afirma que linguagem é ação, ou seja, o processo que vai desde a enunciação, a ação que se realiza somente na linguagem (como promessa, ordem, pedido de desculpa e, neste caso, a securitização), até o convencimento do interlocutor a realizar a ação que se propõe (perlocução), como cumprir a promessa, aceitar a ordem ou o pedido de desculpa ou securitizar uma ameaça. Essa diferença é importante porque houve muita confusão na interpretação da afirmação de Austin de que falar é agir, na teoria de Relações Internacionais.
} 
isso, os autores sugerem que o caminho para o estudo das securitizações é estudar o discurso e as constelações políticas, pela seguinte indagação:

\begin{abstract}
"When does an argument with this particular rhetorical and semiotic structure achieve sufficient effect to make an audience tolerate violations of rules that would otherwise have to be obeyed? If by means of an argument about the priority and urgency of an existential threat the securitising actor has managed to break free of procedures or rules he or she would otherwise be bound by, we are witnessing a case of securitisation" (BUZAN et alii: 1998, p. 25).
\end{abstract}

A relação entre os atores não é simétrica, o que os autores explicam pelas diferentes capacidades de influência de cada Estado, de acordo com a capacidade de ação de cada um deles, que vai desde seu imediato entorno até o regional e sistêmico $^{12}$ - capacidade com base na qual os autores definem diferentes categorias de Estados: superpotência, que tem capacidade plena para atuar no nível internacional; grande potência, que tem capacidade limitada para atuar no nível internacional e que é levada em conta nos cálculos de segurança da superpotência; potência regional, que tem alta capacidade de projeção em sua região, mas tem baixa projeção no nível internacional; potências secundárias (BUZAN e WAEVER, 2003). Essas diferenças são variáveis que influenciam no processo de securitização - alguns atores têm mais poder do que outros para securitizar, mas esse poder não é absoluto:

"No one is guaranteed the ability to make people accept a claim for necessary security action, nor is anyone excluded from attempts to articulate alternative interpretations of security. This field is structured or biased, but no one conclusively 'holds' the power of securitization." (Idem: p. 31).

Por isso, o foco da análise deve ser o processo de securitização, não os atores em si. Essa afirmação decorre da ideia de que não se podem adotar padrões fixos nos temas de segurança, já que, além de tratar de cenários possíveis no futuro, a segurança depende dos sujeitos que articulam as ameaças, daí a grande importância atribuída ao ato de fala. Para que o processo de securitização se complete é, porém, necessário que o interlocutor o aprove, o que não depende apenas do discurso em si. É necessário que se tenham condições - materiais, políticas, culturais - que estão para

\footnotetext{
${ }^{12}$ A Escola de Copenhague propõe quatro níveis de análise no estudo das RI: o nível doméstico, o nível regional, o nível inter-regional e o nível global ou sistêmico. Inicialmente, os autores privilegiaram o nível regional (ou seja, "de baixo para cima" no grau de engajamento entre os atores), com base na Teoria dos Complexos Regionais de Segurança. Posteriormente, pela noção de macrossecuritização, buscaram entender o processo de securitização do nível sistêmico para o doméstico ("de cima para baixo", ou seja, como as securitizações das superpotências interferem nos demais níveis).
} 
além do ato de fala, para que se securitize, de fato, uma ameaça. Os autores recomendam que, para analisar um processo de securitização, é necessário que o pesquisador acate, além do discurso em si, questões extradiscursivas, como a cultura e as instituições dentro das quais o sujeito securitizador se insere.

A combinação discurso e cultura, aos moldes de Bourdieu (BUZAN e WAEVER, 2003), nos processos de securitização é a base que os autores utilizam para fundamentar a Teoria dos Complexos de Segurança (BUZAN, 1991; BUZAN e WAEVER, 1997), ponto de partida para a Teoria dos Complexos Regionais de Segurança, desenvolvida posteriormente (2003). Se por um lado os Estados, atores posicionais, já que têm fronteiras definidas e territórios, são tidos como principal ator, e por outro a natureza das ameaças é relacional e intersubjetiva, os Complexos de Segurança seriam resultado de processos de securitizações empreendidos por diversos atores que dialogam entre si. Esse diálogo raramente ocorre no nível sistêmico, porque nem todos os atores são capazes de atuar mundialmente. Ao considerar a proximidade territorial, Buzan e Waever concluem que os processos de securitização se concentrariam, principalmente, no nível regional (embora não dispensem o nível sistêmico). Assim, para entender os processos de securitização de determinado Estado, seria interessante considerar 0 entorno desse Estado, considerando-se os processos de securitização de seus vizinhos. A relação entre eles pode ser de amizade ou de inimizade, de acordo com a percepção de cada uma das unidades.

A síntese da ideia dos Complexos de Segurança iniciada por Buzan em 1991 é apresentada em 2003, na obra Regions and Powers, na qual os autores se voltam para a análise do nível regional para compreender as dinâmicas de segurança. A Teoria dos Complexos de Segurança fornece a base para a análise que se pretende realizar neste trabalho, por admitir que as securitizações são atos de fala, segmentar os níveis de análise (interno, regional, inter-regional e global) e considerar a proximidade territorial como variável importante nos processos de securitização. Seus pressupostos serão apresentados a seguir. 


\subsection{O Complexo de Segurança Sul-americano e a macrossecuritização da Guerra ao Terror}

A formação de Complexos Regionais de Segurança (CRS), segundo a teoria correspondente, seria consequência direta da combinação de dois elementos: por um lado, a estrutura anárquica do sistema internacional e os mecanismos de balanço de poder referentes a ela e, por outro, as pressões resultantes da proximidade geográfica entre as nações. A proximidade territorial é dado fundamental para que se compreenda como os países percebem as ameaças, já que a grande maioria deles não goza de condições (materiais e políticas) para atuar no nível sistêmico (ou seja, em todas as partes do globo). O nível regional seria, assim, o teatro da interação para a maior parte dos atores (não necessariamente, mas principalmente, os Estados), sendo esse nível de especial importância para compreender as dinâmicas de securitização e definição de ameaça entre tais atores. Os Complexos de Segurança são definidos pelos autores por:

"A set of units whose major processes of securitisation, desecuritisation, or both are so interlinked that their security problems cannot reasonably be analysed or resolved apart from one other." ( BUZAN e WAEVER. 2003: 44).

Assim, no primeiro momento a Escola de Copenhague privilegiou a análise das securitizações no nível médio - isto é, o regional -, no qual as coletividades políticas constroem suas relações de amizade/inimizade. Como se daria, porém, a relação das securitizações regionais, ou constelações de segurança, no nível sistêmico? Foi em 2008, ao explorar com profundidade as constelações de segurança e introduzir a ideia de macrossecuritizações, que Buzan e Waever buscaram melhor articular a análise entre o nível regional e o sistêmico, de forma a compreender padrões de securitização nas relações internacionais.

"Just as in regional security complex theory, securitisations can be bound together positively (where a group of actors share, or partly share, a definition of threat and referent object), or negatively (where actors, or groups of actors, construct each other as threats) in the process forming potentially durable patterns of security interdependence. We have already researched in detail how this type of security interdependence works at the regional level, and part of what we want to do here is to push that logic beyond the regional level." (BUZAN e WAEVER: 2008, p. 256)

"In thinking about the sources of macrosecuritisations and constellations, one has also to ask who generates them, how, and for what purpose? 
Macrosecuritisations, like all securitisations, require securitising actors, appropriate speech acts, and responsive audiences. In addition they require some expansive dynamic capable of subsuming other securitisations. Only if they acquire a supportive audience on an appropriate scale and a possibility to operate as the interpretive framework for other securitisations do they have the possibility of becoming more than niche securitisations, however macro their logic and however ambitious the aspiration of their promoters." (Idem: p. 265)

Entender o processo de macrossecuritização significa, basicamente, analisar a maneira como os processos de securitização nos níveis subsistêmicos (principalmente, o regional e o doméstico) são influenciados pelo nível sistêmico. Para isso, seria necessário entender os processos de securitização das superpotências (aquelas de capacidade de atuação e influência globais, que, atualmente, se resumem nos Estados Unidos da América) e verificar em que medida eles interferem nos processos de securitização nos outros níveis. Macrossecuritização dá-se quando uma ameaça articulada pela superpotência é incorporada por larga parcela dos atores, que a rearticulam e a incorporam como ameaça às suas próprias existências. A Guerra Fria é o maior exemplo de macrossecuritização, já que a disputa bipolar ensejou uma série de securitizações em todos os níveis (em especial no nível doméstico), quando governos se apropriaram da ameaça comunista para justificar medidas extraordinárias em seus países, mesmo que na "periferia" do sistema (o grande exemplo são os Golpes Militares ocorridos na América Latina).

\begin{abstract}
"Just as in regional security complex theory, securitisations can be bound together positively (where a group of actors share, or partly share, a definition of threat and referent object), or negatively (where actors, or groups of actors, construct each other as threats) in the process forming potentially durable patterns of security interdependence. We have already researched in detail how this type of security interdependence works at the regional level, and part of what we want to do here is to push that logic beyond the regional level." (Idem: p 256)
\end{abstract}

Os autores definem as macrossecuritizações pelas regras das outras securitizações: identificação de objeto de referência como ameaça e evocação de medidas excepcionais para combatê-la. As macrossecuritizações, por funcionar no nível sistêmico e pretender influenciar constelações de segurança, guardariam, porém, estrutura mais complexa:

"The key difference is that they are on a larger scale than the mainstream collectivities at the middle level (states, nations) and seek to package together securitisations from that level into a 'higher' and larger order. Macrosecuritisations have a more complicated structure than ordinary ones. 
Because they contain both higher and lower level securitisations they embody permanent tensions across the levels, and are vulnerable to breakdowns not just by desecuritisation of the macro-level threat (or referent object) as at the end of the Cold War, but also by the middle level securitisations becoming disaffected with, or pulling away from, subordination to the higher level one, such as the Sino-Soviet split." (BUZAN e WAEVER: 2008, p. 257).

Com base nessa construção teórica, os autores identificam na estratégia de Guerra ao Terror (Global War on Terror, GWoT, sigla em inglês) tentativa, por parte dos norte-americanos, de criar macrossecuritização, pelas intenções universalistas articuladas, quando o Governo Bush advoga que determinado padrão de segurança sirva de moldura para o resto do mundo, explicitadas no embate entre o "mundo civilizado", ou seja, o bem, e o mundo não civilizado - terroristas, Estados Páreas ou todos aqueles que não estão do lado dos norte-americanos -, o mal.

\footnotetext{
"The most powerful macrosecuritisations, such as the Cold War, will impose a hierarchy on the lower level ones incorporated within them, but it is also possible for a macrosecuritisation simply to bundle other securitisations together without necessarily outranking them. The GWoT seems mainly to work this way in relation to the securitisations of drugs, crime and weapons of mass destruction." (Idem, p. 257)
}

A hipótese dos autores é que a GWoT tenha ensejado securitizações em outros níveis (ou seja, macrosecuritização), embora de forma menos intensa do que a macrossecuritização do período da Guerra Fria. Para testar essa hipótese e compreender como essa macrossecuritização teria ocorrido, seria necessário comparar a ameaça articulada no nível sistêmico com a articulação da ameaça nos demais níveis. O primeiro passo para isso seria identificar como cada um dos atores dialogam com essa securitização. Dessa forma, é preciso voltar-se para os discursos desses atores e identificar a intertextualidade na concepção das ameaças. Tal tarefa é a que se pretende realizar neste trabalho, pela análise dos discursos dos representantes de três países sul-americanos: Brasil, Colômbia e Venezuela.

Como já mencionado, o ato de fala é uma das fases do processo de securitização, que só se completa quando o destinatário do discurso acata o argumento como legítimo, dando espaço para adoção de medidas urgentes para combater a ameaça. Essa segunda fase não será objeto de análise deste trabalho, já que se privilegia análise pormenorizada dos discursos (que sirva como base para posteriores análises). Isso se justifica porque, apesar da importância do nível discursivo no 
processo de securitização, grande parcela dos trabalhos que se sustentam nessa teoria se concentra na segunda fase da securitização, não raro negligenciando o processo de articulação e reduzindo-o a ameaça de nível discursivo, sem o qual não se pode conceber a securitização.

Finalmente, a Escola de Copenhague fornece meio-termo entre os argumentos tradicionais e os pós-positivistas, oferecendo aparato teórico consistente para estudos que combinam segurança e discurso. Pela caracterização dos processos de securitização, que é ato de fala, consequentemente subjetivo e relacional, cujo êxito depende do engajamento da audiência, os autores da Escola mostraram como diferentes assuntos podem ser elevados ao status de ameaça. Com os Complexos de Segurança Regionais, endereçou-se a interação entre os atores cuja proximidade física torna seus processos de securitização atrelados, mantendo-se entre eles diálogo constante. Para compreender a interação entre diferentes processos de securitização regionais (a que se chamou constelações), entre si, no nível sistêmico, os autores desenvolveram o conceito de macrossecuritização. Disso se pode auferir que, se a desigualdade entre os atores faz que ameaças sejam securitizadas de maneira desigual e se os Estados Unidos da América são considerados a única superpotência, de capacidade de atuação no nível sistêmico, os norte-americanos teriam grande possibilidade de que seus processos de securitização fossem aceitos pelos demais atores. Quando identificam que houve tentativa do Governo Bush de influenciar a definição de ameaça pelos demais atores com a Guerra ao Terror, seguindo essa tradição, é preciso voltar-se para os demais atores e ver como seus processos de securitização dialogam com o Governo Bush.

Assim, com base nos trabalhos daqueles autores, parte-se da premissa de que, embora a América do Sul não seja de prioridade estratégica para os Estados Unidos, para os membros do Complexo Regional de Segurança Sul-americano (CRSSA) as relações entre o nível regional e o global se dão, essencialmente, pela interlocução com os Estados Unidos. As estratégias de segurança desses países seriam constantemente permeadas pela relação que estabelecem com a superpotência (seja de aproximação ou de afastamento). A influência dos Estados Unidos na região seria, no entanto, de caráter de penetração e não de solapamento. $A$ atenção dada em especial à Doutrina Bush e a tentativa de compreender sua incorporação nos discursos sul-americanos são justificadas pela Teoria das Macrossecurizações. 
Desse modo, a escolha dos três países - Brasil, Colômbia e Venezuela - como amostra se justifica, em primeiro lugar, pela importância desses países na região, militar, social e economicamente, já que na América do Sul não há grande potência. Dessa forma, são as potências regionais responsáveis por definir as polaridades dentro do CRS, ou seja, a partir da análise das políticas das potências regionais, seria possível estabelecer panorama de como se dá a interação entre elas e os minor powers e também a forma de penetração no CRS pelas potências globais. No caso do CRSSA, onde, segundo os autores, não há uma única potência regional (sendo ele, portanto, multipolar), verifica-se a existência de quatro eixos principais de poder, que giram em torno de Argentina, Brasil, Colômbia, Chile e Venezuela ${ }^{13}$.

Além de apresentar os maiores PIB e os maiores contingentes militares ${ }^{14}$ da região, esses países estão engajados em diferentes dinâmicas sub-regionais e travam relações bastante diversas com os EUA. No norte andino, Colômbia e Venezuela estabelecem relações opostas com a superpotência; no caso da Colômbia, é de grande engajamento e alinhamento (em especial após o Plano Colômbia) e, no da Venezuela, após a presidência de Hugo Chávez, a relação é de atrito e de politização do diálogo. No Cone Sul, Brasil e Argentina hesitam entre posições de cooperação e posições de desconfiança relativamente aos norte-americanos: o Brasil busca conter a influência da superpotência por meio de diversificação de parcerias regionais e de parcerias globais; a Argentina, após o fracasso da política de alinhamento com os EUA nos anos 1990, tem buscado cooperação mais pragmática e aproximação com os vizinhos, em especial com o Brasil (BUZAN e WAEVER: 2003).

Considerado que a região sul-americana é bastante heterogênea e que a presença dos Estados Unidos no continente é complexa, é importante compreender como se dá a articulação das ameaças e os interdiscursos dos países sul-americanos em relação ao discurso da potência mundial, identificando-se os elementos associativos e/ou os dissociativos entre eles. Para tanto, voltar-se-á à análise dos discursos desses países no próximo artigo. Antes disso, é necessário que se introduza metodologia de análise do discurso mais voltada à Linguística, já que, assim como as demais vertentes de Análise do Discurso nas RI, a Escola de Copenhague não se

\footnotetext{
${ }^{13}$ Por razões de concisão e de propósito de Dissertação de Mestrado, optou-se pela análise de três desses países, deixando-se fora Argentina e Chile. A Escolha de Brasil, Colômbia e Venezuela foi motivada por acreditar-se que esses países teriam as posições mais distintas entre si, sendo, portanto, bastante representativas por englobar dois polos de um espectro de posições (Colômbia em um extremo, Brasil no centro e Venezuela no outro extremo).

${ }^{14}$ http://www.eclac.cl/cgibin/getProd.asp?xml=/deype/agrupadores xml/aes250.xml.
} 
aprofundou nos instrumentais da Análise do Discurso em si (em especial porque o ato de fala é uma das fases da securitização, mas é, sem dúvida, o mais importante). Para suprir essa lacuna, apresentam-se os pressupostos da Análise Crítica do Discurso $(A C D)$ e, posteriormente, breve discussão do instrumental linguístico que pautará o estudo de caso no segundo artigo.

\section{Análise Crítica do Discurso (ACD)}

A Análise Crítica do Discurso (Critical Discourse Analysis) considera que a linguagem em uso é prática social e que, por conseguinte, apresenta consequências políticas, como status, solidariedade, distribuição de bens sociais e poder (FAIRCLOUGH, MULDERRIG e WODAK, 2009). Baseia-se em metodologia multidisciplinar para sustentar concepção dialética entre linguagem e sociedade. As implicações dos discursos na realidade são elemento que distingue os teóricos da ACD dos pós-estruturalistas, que se restringem aos significados dos textos, sem considerar o contexto em que eles se inserem (Laclau e Mouffe, por exemplo, ignoram os efeitos das práticas extradiscursivas).

Os autores da ACD afirmam que, para entender como as relações de poder são exercidas e negociadas pelo discurso, o contexto é de grande importância, porque é capaz de afetar a interpretação dos discursos. A ACD incorpora uma serie de abordagens (Fairclough foca as mudanças sociais, para entender como e em que medida essas mudanças ocorrem no discurso; Teun van Dijk, por meio de abordagens cognitivas, busca entender as dimensões cognitivas nas quais o discurso articula questões como preconceito, ideologia e conhecimento; Paul Chilton, também em viés cognitivo, estudou o discurso político; Ruth Wodak, por meio de perspectiva histórica, busca integrar às análises do texto interpretações anteriores; van Leeuwen e Muldering privilegiam a análise dos movimentos retóricos de persuasão e de legitimação na linguagem) que compartilham o interesse pelas dimensões semióticas do poder, do preconceito, das mudanças políticas, econômicas e culturais na sociedade.

Ao contrário de outras correntes de estudos do discurso, a ACD não define os instrumentos metodológicos a priori. A pesquisa começa com um tópico (no caso deste trabalho, a ameaça terrorista), para que, depois de formulada a pergunta de pesquisa 
(houve macrossecuritização da Guerra ao Terror?), o analista possa escolher os métodos apropriados. Questões de segurança, por exemplo, são vistas não só por seus aspectos militares, mas também pela forma como as estratégias linguísticas foram usadas para produzir e legitimar a ação (convergindo com a explicação da Escola de Copenhague sobre macrossecuritização).

\footnotetext{
"Meaning is not merely a matter of recording grammar, it is also (and more importantly) a matter of knowing which of the many inferences the one can draw from an utterance are relevant. And 'relevance' is a matter deeply tied to context, point of view, and culture." (LEE 2011, p. 54)
}

Por considerar a reciprocidade entre o contexto (extradiscursivo) e o discurso, os autores da $A C D$ alegam que a linguagem não só constrói mas também reflete 0 contexto em que é empregada. A Análise do Discurso seria, então, empregada para explicitar as relações desiguais em determinada sociedade. Outro aspecto fundamental da CDA é a noção de que o poder é a condição central da vida social. O poder resulta em relações e efeitos distintos na estrutura social, e o impacto das práticas discursivas depende de como elas interagem com a realidade pré-constituída.

\begin{abstract}
"Power does not derive from language, but language can be used to challenge power, to subvert it, to alter distributions of power in the short and long term. Language provides a finely articulated means for differences in power in social hierarchical structures." (WODAK 2009: p. 11)
\end{abstract}

Os trabalhos produzidos pela ACD dialogam com as obras de clássicos como Foucault, Bourdieu, Bakhtin e Gramsci. A obra deste último tem importância fundamental para a Escola; adota a perspectiva de hegemonia não apenas como dominância e força, mas como processo de negociação do qual se produz consenso em torno das práticas sociais e dos significados. De acordo com Fairclough, a hegemonia, como proposta por Gramsci, é fundamental para análise do discurso, pois oferece a base teórica a partir da qual o analista pode compreender a maneira como a prática discursiva está integrada ao macro-contexto das relações de poder.

"Gramsci's observation that the maintenance of contemporary power rests not only on coercive force but also on 'hegemony' (winning the consent of the majority) has been particularly influential in CDA. The emphasis on hegemony entails an emphasis on ideology, and on how the structures and practices of ordinary life routinely normalize capitalist social relations (...) Foucault's work on discourse has generated immense interest in discourse analysis, but also of a rather abstract sort that is not anchored in a close analysis of particular text. 
For Foucault discourses are knowledge systems (...) which constitute power in modern society (...) A further influential figure is Pierre Bourdieu, in particular his work (1991) on the relationship between language, social position and symbolic value in power relations. From linguistics and literary studies the work od Mikhail Bakhtin (1986) has been important in discourse analysis (...) Bakhtin's work emphasizes the dialogical properties of texts, introducing the idea of 'intertextuality' (...), that any text is a link in a chain of texts, reacting to drawing to and transforming other texts." (FAIRCLOUGH, MULDERRIG and WODAK 2009: p.361)

Em outras palavras, a ACD se interessa pela manipulação da linguagem em que se expressa o poder (KODAK, 2009). Para isso, é necessário que se analise o discurso (texto) levando-se em conta a situação de comunicação, ou seja, a produção e o consumo dos textos, que por sua vez fazem parte de uma série de práticas sociais, características de cada sociedade. A análise do discurso proposta pela ACD deveria, então, voltar-se para três camadas de significação: a) significações advindas da análise do texto, das estruturas linguístico-formais; b) a situação de enunciação, isso é, a prática discursiva, que altera a forma do discurso; c) as práticas sociais, examinandose a maneira como o discurso dialoga com outros discursos (intertextualidade).

Dessa forma, o pesquisador estaria interessado em observar como determinados discursos reproduzem ou reestruturam conceitos e práticas, de forma a identificar quais são as macro-consequências desses discursos para práticas sociais. Como afirma Van Dijk $(2005,66)$ :

\begin{abstract}
"My general framework is a multidisciplinary brand of critical discourse analysis (CDA) that tries to 'triangulate' social issues in terms of a combined study of discursive, cognitive and social dimensions of a problem (Van Dijk: 1993, 2003). Thus, in our case, we are interested not just in describing some interesting properties of political rhetoric, but in order to explain them, we need to relate them to such sociocognitive representations as attitudes, norms, values and ideologies."
\end{abstract}

Os três níveis de significação, ilustrados por Fairglough na figura abaixo, devem ser analisados, porque, segundo acredita o autor, nenhum texto deveria ser analisado isoladamente, já que os discursos podem ser compreendidos apenas se inseridos no contexto social e no emaranhado de diversos textos e conceitos com os quais esses discursos se relacionam. 
Figura 1. Modelo tridimensional da Análise do Discurso (in FAIRCLAUGH,1992:73)

\section{Modelo tridimensional da Análise do Discurso}

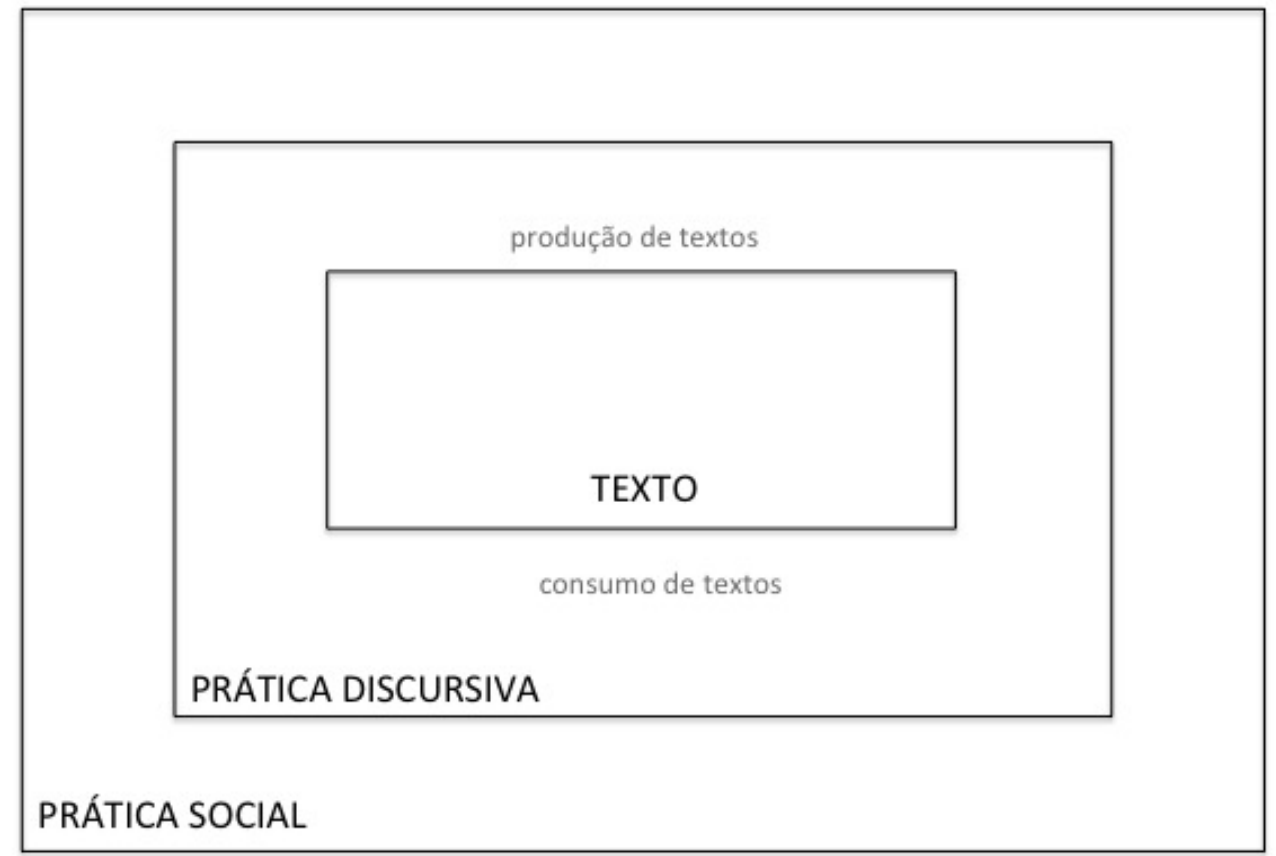

A análise do discurso político e das dimensões desses discursos que passam despercebidas foi incorporada por estudiosos como van Dijk, Kodak e Chilton. Em linhas gerais, esses teóricos entendem que o pesquisador que se propõe a realizar análise do discurso político deve relacionar o comportamento linguístico com 0 comportamento político. Este é entendido como aquelas ações (de ordem linguística ou não) que envolvem poder ou, ao contrário, resistência (WODAK, 1997 p. 311). Segundo Chilton e Schäffner (2009, p. 313), as funções estratégicas dos discursos políticos podem ser desveladas pela análise dos níveis linguísticos, que envolvem a pragmática (interação entre falante e ouvinte), a semântica (significado, estrutura lexical) e a sintaxe (organização interna das sentenças) .O autor ressalva, no entanto, que o uso da linguística não está restrito à estrutura do texto, ao léxico e à sintaxe por si mesmos, mas estende-se aos mecanismos pelos quais destinador (aquele que produz a mensagem) e destinatários (aqueles que recebem a mensagem) produzem significados complexos e diversos (o que grandemente inclui a pragmática e as práticas sociais). 


\section{Metodologia}

Nesta seção, apresentam-se as premissas metodológicas que serão utilizadas para identificar os processos de securitização da ameaça ao terrorismo, para verificar até que ponto houve a macrossecuritização da Guerra ao Terror na América do Sul, empreendida pelos presidentes sul-americanos.

Não se pode estudar a linguagem, como a conhecemos hoje, sem citar os trabalhos de Ferdinand de Saussure, conhecido como o Pai da Linguística. Em Curso de linguística geral, Saussure desenvolveu a Teoria dos Signos, revolucionando os estudos da língua, que antes eram conduzidos de maneira diacrônica e comparativa (comparavam-se línguas e normas no processo histórico, sem que se desse atenção ao estado da língua no momento em que se estudava). Ao propor que o signo (a "palavra", como chamamos vulgarmente) é formado por um significante, que Saussure descreve como imagem mental sonora, e um significado, que estabeleceria a relação entre o objeto do mundo e a imagem sonora, Saussure situa a unidade mínima de sentido na abstração (significado e significante), não no concreto, no objeto (OSAKABE, 1999).

Saussure foi o primeiro a afirmar que não existe realidade fora da língua. Assim, distancia-se das ideias que se baseavam no inatismo (retomadas as ideias de Platão) e no universalismo da língua, segundo os quais se afirmava que os conceitos eram preexistentes à linguagem. Para Saussure não haveria conceito intrínseco ao objeto: ele só passa a ser compreendido como tal porque a linguagem funciona como recorte simbólico (PIERCE, 1992).

Ao estudar a linguagem, no entanto, Saussure se volta para os estudos da língua, abstratamente, ignorando a fala, que é o uso concreto da língua. A marginalização da língua em uso, ou seja, da fala concreta, como objeto do estudo da linguagem, a partir dos trabalhos de Saussure, influenciou muitos dos trabalhos na Linguística, que negligenciaram a relação entre a estrutura da linguagem e seu uso, já que se acreditava que o estudo da fala se concentraria apenas nos usos singulares, que teriam pouca relevância para as análises da Linguística, que deveria estar 
preocupada com as regras gerais da linguagem (FIORIN, 2004). Foi só a partir dos trabalhos de John Austin e Paul Grice ${ }^{15}$ que os estudos de Linguística reconciliaram o uso com os estudos da linguagem, a partir da percepção de que a interpretação de certos enunciados depende não apenas das oposições fônicas e semânticas e das regras combinatórias da Sintaxe, mas, também, da compreensão das circunstâncias da situação concreta da fala (Pragmática).

Ao perceber que trocas verbais podem comunicar muito mais do que as palavras significam, Austin afirmou que a fala não serve apenas para descrever as coisas no mundo e que, em muitos casos, certas ações só se realizam na linguagem. Disso decorre a afirmação de que, ao falar, o homem também age, dando-se origem à teoria dos "atos de fala", que se popularizou não só na Linguística, mas também em outras áreas das Ciências Humanas. É necessário, no entanto, que se defina o que Austin entende por "agir na linguagem", para evitar confusões que essa afirmação pode gerar.

Antes da Pragmática - o campo da Linguística destinado aos princípios gerais que regem o uso da língua (que vão além dos usos particulares) -, acreditava-se que, ao proferir um enunciado, o enunciador ${ }^{16}$ (aquele que fala) estaria interessado em descrever o estado das coisas no mundo. Assim, um enunciado poderia ser analisado por suas condições de verdade ou falsidade, ou seja, uma afirmação como "o céu está azul" poderia ser verdadeira ou falsa. Essa "ilusão descritiva da Linguística", explica Fiorin (2004, p. 170), ignorava enunciados aos quais a lógica "verdadeiro ou falso" não se aplicaria, como em "ordeno que você saia daqui".

Aos enunciados que não atendiam à lógica dos enunciados constativos, por não se enquadrarem nas questões de verdadeiro ou falso, Austin chamou performativos. Os enunciados performativos, observou Austin, são mais do que enunciados; são a ação, porque a própria enunciação corresponde à ação em si: uma promessa pode ser realizada somente a partir da realização linguística da promessa: "eu prometo que

\footnotetext{
${ }^{15}$ Em sua obra, Grice (1975) trabalha os conteúdos implícitos da fala, a partir dos conceitos de implicatura e cooperação como princípios gerais da comunicação, que lhe permitem formular uma teoria de Pressupostos e Subentendidos. Como este trabalho busca realizar uma análise do discurso a partir dos atos de fala explícitos, a obra de Grice, apesar de sua importância para a Pragmática, não será aqui discutida.

16 Há, na Linguística, grande discussão que explicita as diferenças entre falante/ouvinte, enunciador/enunciatário, destinador/receptor. Neste trabalho, assumem-se os termos como sinônimos. Para estudo completo da enunciação, ver Luiz Fiorin (1996).
} 
virei". A esse tipo de enunciado é que Austin se refere ao afirmar que, ao falar, o sujeito também age ${ }^{17}$.

Quando diferencia os enunciados constativos dos performativos, Austin procura entender o que se faz quando se profere um enunciado. A partir daí, define três atos: o locucional, o ilocucional e o perlocucional. O primeiro, o ato locucional ou locucionário, corresponde à fala em si, ou seja, o ato linguístico de proferir sentença, a enunciação de cada uma das palavras que compõem a frase; o segundo, o ato ilocucional ou ilocucionário, é aquele que se realiza na linguagem, no próprio ato de dizer (no enunciado "proíbo que você saia", o ato de proibir se realiza quando a sentença é proferida); o terceiro, o ato perlocucional ou perlocutório, é realizado pela linguagem: no caso da frase "proíbo que você saia", a adesão do interlocutor à proibição, no caso aceitar permanecer no local, é realizada não na linguagem, mas em decorrência da enunciação da proibição, ou seja, é realizada pela linguagem (AUSTIN, 1990). A partir dessa definição, pode-se afirmar que, ao proferir um enunciado (constativo ou performativo), o locutor realiza ato locucionário. O ato ilocutório (ilocucionário ou ilocucional) corresponderia à enunciação dos enunciados performativos, que por sua vez dependem da adesão do interlocutor para se completar, caracterizando-se, dessa forma, a perlocução (nota-se que o processo de securitização proposto pela Escola de Copenhague adere a todas as fases propostas por Austin).

\begin{abstract}
"O locutor só se define enquanto tal, isso é, só produz efetivamente seu discurso a partir do pressuposto (sua veracidade não entra em questão) de que a imagem que faz do referente é virtualmente distinta da imagem que pressupõe que o ouvinte lhe faz. $\mathrm{O}$ ato de argumentar constitui uma espécie de operação que visa fazer com que o ouvinte não apenas se inteire da imagem que o locutor faz do referente, mas principalmente que o ouvinte aceite essa imagem (OSAKABE: 2002,p 93)
\end{abstract}

Para que um ato ilocucionário possa levar ao ato perlocucionário ${ }^{18}$ (BENVENISTE, 1966), é, no entanto, necessário que a situação de comunicação

\footnotetext{
17 Outros exemplos de performativos seriam promessas, pedidos de desculpa, ameaças etc. No primeiro momento, Austin acreditava possível realizar um teste puramente linguístico para identificar enunciados performativos (por exemplo, verbos expressos na primeira pessoa do singular do presente do indicativo na voz ativa). Pelo estudo de enunciados como "Proibido fumar", Austin afirma, no entanto, que um performativo não precisa estar no tempo verbal acima descrito para que se possa considerá-lo como tal. $\mathrm{O}$ autor reelabora o conceito dizendo que performativos são os enunciados que permitam ser refraseados utilizado-se a primeira pessoa do presente do indicativo da voz ativa.

${ }^{18}$ Benveniste desenvolve a questão dos atos perlocutórios ao realizar análise crítica dos atos de fala de Austin, que associa a fiduciabilidade da fonte produtora do discurso ao resultado da enunciação. Assim, não basta apenas o conteúdo da enunciação para que ocorra a perlocução, mas é também relevante a
} 
preencha uma série de requisitos. Em primeiro lugar, os participantes devem reconhecer-se como legítimos. Para que um discurso produza efeito, é necessário que se estabeleça relação de confiança entre os interlocutores, prévia à enunciação, de caráter extradiscursivo. A fiduciabilidade do discurso é imprescindível para que ocorra a perlocução. Essa relação de confiança pode ser ilustrada, por exemplo, quando um juiz exprime sentença e declara um indivíduo culpado (ilocução): a pena se aplica (perlocução) somente porque há o consentimento entre as partes de que o juiz goza de legitimidade para isso. Por outro lado, quando um estudante declara um suspeito "culpado", a percolação não ocorre, porque o enunciatário não goza de legitimidade discursiva para tal. Performativos proferidos por agentes não legitimados constituem ato de fala abusivo. Além disso, é preciso que os participantes da enunciação compartilhem certos conhecimentos de mundo. Dessa forma, a compreensão dos significados estaria não na abstração, como afirmou Saussure, mas na situação da fala, na realização do enunciado, considerando-se também o contexto. Nesse caso, os interlocutores se apresentam como identidades reais, mutuamente determinadas (FIORIN, 2004).

O programa de Austin foi retomado por John Searle (1968), que aprofundou a Teoria dos Atos de Fala, ao refinar a análise dos atos ilocucionários. Searle redefine as categorias dos atos de fala ilocucionários classificando-os em cinco categorias:

1) atos de fala assertivos: demonstram o comprometimento do falante em relação à veracidade do enunciado que expressa;

2) atos de fala diretivos: incitam o locutário a realizar ação (pedidos, comandos, ordens);

3) atos de fala comissivos: por eles os locutores se comprometem a realizar ação no futuro (como promessa);

4) atos de fala expressivos: contêm as atitudes e emoções do locutário diante de uma situação (pedidos de desculpa, agradecimentos, cumprimentos);

5) atos de fala declarativos: mudam a realidade depois de proferidos (batismos, pronunciamento de sentença em que se declara um indivíduo culpado, declaração de abertura de sessões etc.).

posição enunciativa do ator. É Benveniste que introduz a importância do sujeito na Teoria da Enunciação. 
A determinação dos atos de fala deve levar em consideração não apenas o tipo de verbo, mas também a sintaxe, em especial a predicação. A compreensão de movimentos de modalização fortalece a análise, por explicitar o posicionamento do emissor em relação ao que se diz. Assim, este trabalho procura compreender os processos de securitização na sua fase discursiva não apenas no nível superficial, mas, sim, entender como esses processos são articulados, quais atos de fala se apresentam e como são modalizados. Aprofundar a análise dos aspectos linguísticos nos discursos em que uma ameaça é securitizada é capaz de explicitar o significado profundo das significações, bem como a interlocução com outros textos, o engajamento do enunciador com o enunciado proferido, e ainda apontar para os pressupostos e subentendidos sob os quais esses discursos se sustentam.

\section{CONCLUSÃO}

Neste artigo, buscou-se apresentar o processo de expansão de fronteiras da discussão teórica nas Relações Internacionais que permitiu a adesão de novos temas e objetos ao estudo da disciplina. Em seguida, discorreu-se sobre alguns dos trabalhos voltados para a Análise do Discurso nas Relações Internacionais e sobre a incorporação do objeto discurso nos Estudos de Segurança, apresentando-se também algumas das análises do discurso da Guerra ao Terror. Para tentar responder às críticas que os trabalhos do discurso, em especial de viés pós-positivista, receberam, advogou-se pela adoção do aparato teórico da Escola de Copenhague em conjunto com a Análise Crítica do Discurso. Com base nas formulações teóricas de Barry Buzan e Ole Waever, justificou-se a importância da análise do discurso como fase fundamental no processo de securitização, sem o qual não se pode falar de macrossecuritizações. Para tanto, argumentou-se a favor do uso de instrumentos linguísticos que diminuem a influência das opiniões pessoais do analista e propiciam análise mais sólida dos significados profundos dos discursos em questão. Entende-se que tal incursão teórico-metodológica, apresentada neste artigo, é imprescindível para estabelecer e justificar a pertinência do objeto desta pesquisa - verificar a articulação e o processo de securitização da ameaça terrorista nos discursos dos presidentes sul- 
americanos, que sinalizem a macrossecuritização, ou não, da Guerra ao Terror, elaborada pelo Governo Bush após os atentados ao World Trade Center, em setembro de 2001.

\section{Bibliografia}

ADLER, Emanuel (1999). "O Construtivismo no Estudo das Relações Internacionais". In: Lua Nova. Revista de Cultura e Política. Número 47. São Paulo: CEDEC.

ALTHUSSER, Louis (1985, original francês publicado em 1970). Aparelhos ideológicos de Estado. Rio de Janeiro: Graal.

ASHLEY, Richard K.; WALKER, R. B. J (1990). "Introduction: Speaking the language of exile: dissident thought in International Studies". International Studies Quarterly, v. 34, n. 3, p. 259-268, Sep. 1990.

AUSTIN, John Langshaw (1955). How to do things with words: the William James Lectures delivered at Harvard. Oxford: The Claredon Press, 1962.

In:http://www.dwrl.utexas.edu/ davis/crs/rhe321/Austin-How-To-Do-Things.pdf (acesso em 10-12-2014)

BALDWIN, David A (1997). "The concept of security". Review of International Studies, v. 23, n. 1 , p. 5-26, 1997.

BARROS, Sebastián; CASTAGNOLA, Gustavo (2000). "The political frontiers of the social: Argentine politics after Peronist populism (1955-1973)" In: Discourse theory and political analysis: Identities, Hegemonies. HOWARTH, DAVID; NORVAL, Aletta; STAVRAKAKIS, Yannis (Editors). Manchester: Manchester University Press.

BENVENISTE, Emile (1966). Problémes de linguistique générale. vol.I. Paris: Gallimard.

BUZAN, Barry; W/EVER, Ole; DE WILDE, Jaap (1998). Security: a new framework for analysis. London: Lynne Rienner.

; WÆVER, Ole (2003). Regions and powers: the structure of international security. Cambridge: Cambridge University Press.

; WÆVER, Ole (2009). "Macrosecuritisation and security constellations: reconsidering scale in securitisation theory". Review of International Studies, v. 35, p. 253-276, 2009.

CAMPBELL, David (1998). Writing security: United States foreign policy and the politics of identity. 2. Ed. Minneapolis: University of Minnesota Press. 
CHILTON, Paul. SCHÄFFNER, Christina (1997). "Discourse and Politics". In: Discourse studies - a multidisciplinary introduction. T.A VAN Dijk (org.). London: Sage.

BURCHILL, Scott et alli (2001). Theories of International Relations. Second Edition. New York: Palgrave.

DALBY, Simon (1990). Creating the Second War: the discourse of politics. The Guilford Press.

DEBRIX, François (ed.) (2003). Language, agency, and politics in a constructed world. New York: M. E. Sharpe.

DER DERIAN, James; SHAPIRO, Michael (1989). International/Intertextual relations: postmodern readings of world politics. New York: Lexington Books, 1989.

"Letter to a Japanese Friend. (Prof. Izutsu)." In: Derrida and Differance, ed.

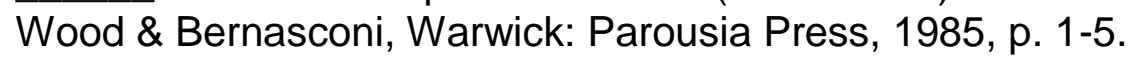

DIJK, Teun A. van (2008). Discurso e poder. São Paulo: Contexto.

(ed.) (1997a). Discourse as structure and process. Discourse studies: a multidisciplinary introduction, v. 1. London, SAGE.

(ed.) (1997b). Discourse as social interaction. Discourse studies: a multidisciplinary introduction, v. 2. London, SAGE.

(2005) 'War rhetoric of a little ally: Political implicatures and Aznar's legitimazation of the war in Iraq". In: Journal of Language and Politics 4:1, 65-91.

FAIRCLOUGH, Norman (1992). Discourse and social change. Cambridge, Polity Press. ; MULDERRIG, Jane. WODAK, Ruth (2009). "Critical Discourse Analysis". In: Discourse studies - a multidisciplinary introduction. T.A VAN Dijk (org.). London: Sage.

FIORIN, José Luiz (org.) (2003). Introdução à Linguística. v. 2: Princípios de análise. São Paulo: Contexto, 2003, p. 187-219.

(org.) (2002) "Pragmática". In: Introdução à Linguística. v. 2: Princípios de análise. São Paulo: Contexto.

(1996). As astúcias da enunciação. São Paulo: Ática.

FIERK, K.M (1998). Changing Games, Changing Strategies: Critical Investigations in Security. Manchester: Manchester Press University.

GRICE, Herbert Paul (1941). "Personal identity". Mind, v. 50, n. 200, p. 330-350, Oct. 1941.

. "Meaning”. The Philosophical Review, v. 66, n. 3, p. 377-88, Jul. 1957. 
GOMES, Áureo de Toledo (2011). "Análise do Discurso e Relações Internacionais: duas abordagens". Revista Política Hoje, Vol. 20, n.2.

HABBERMAS. Jurgen (1984). Theory of Communicative Action, Vol. 1 :Reason and Rationalization of Society. Cambridge: Cambridge University Press.

HANSEN, Lene. (2006). Security as Practice: Discourse Analysis and the Bosnian War. New York: Routledge.

HOFFMAN, M. (1992). "Third Party Mediation and Conflict Resolution in the Post-Cold War World", in J. Baylis and / Rengger (ed.), Dilemas of world politics. New York / Oxford. The Clarendon Press / Oxford University Press.

HOPF, Ted (1998). "The Promise of Constructivism in International Relations Theory". International Security. v. 23, n. 1, p. 171-200. The MIT Press.

JARVIS, Lee, (2009). Times of Terror: discourse, temporality and the War on Terror. New York: Palgrave.

JORGENSEN, Marianne; PHILLIPS, Lousie, (2002). Discourse Analysis as Theory and Method. London: Sage.

KEOHANE, Robert O. ; NYE Jr., Joseph (1977). Power and Interdependence: World Politics in Transition. Boston: Little Brown and Company.

KRATOCHWIL, Friedrich (1989). Rules, norms and decisions: on the conditions of practical and legal reasoning in international relations and domestic affairs. Cambridge studies in international relations. Cambridge: Cambridge University Press.

LACLAU, Ernesto; MOUFFE, Chantal (1985). Hegemony and the Socialist Strategy: towards a radical democratic politics. London: Verso.

LAPID, Yosef (1989). "The third debate: on the prospects of international theory in a post-positivist era". International Studies Quarterly, v. 33, n. 3, p. 235-54, Sep. 1989.

LINKLATER, Richard (1998). The Transformation of Political Community: Ethical Foundations of the Post-westphalian Era. Polity Press.

LYNN-DOTY, Roxanne (1993). "Foreign Policy as Social Construction: a Post-Positivist analysis of U.S. Counterinsurgency Policy in Philippines". International Studies Quarterly, vol. 37, p.p. 297-320.

MEARSHEIMER, John (1983). Conventional Deterrence. Cornell University Press.

MESSARI, Nizar; NOGUEIRA, João Pontes (2005). Teoria das relações internacionais: correntes e debates. Rio de Janeiro: Elsevier.

MORGENTHAU, Hans Joachim (1948). A política entre as nações: a luta pelo poder e pela paz. Brasília: UnB/IPRI; São Paulo: Imprensa Oficial do Estado de São Paulo, 2003 (original norte-americano publicado em 1948). 
MUSUMECI, Martino Gabriel (2011). Semiótica das securitizações governamentais na América do Sul contemporânea: construção das significações de segurança e defesa em documentos políticos da região. 225 f. Dissertação (Mestrado em Ciência Política) Faculdade de Filosofia, Letras e Ciências Humanas, Universidade de São Paulo, São Paulo, 2011.

NYE Jr., Joseph (2008). Understanding International Conflicts: an Introduction to Theory and History. 7th ed. (Longman).

ONUF, Nicholas Greenwood (1989). World of our making: rules and rule in social theory and international relations. Columbia, S. C.: University of South Carolina Press.

OSAKABE, Haquira (2002). Argumentação e Discurso Político. $2^{2}$ tiragem, São Paulo: Martins Fontes (primeira edição publicada em 1999)

PIERCE, C.S (1992). The essential Peirce: Selected Philosophical Writings, vol. 1. (ed.) N. Houser and C.Kloesel, Bloomington: Indiana University Press.

RESENDE, Erica Simone Almeida (2010). Americanidade, Puritanismo e Política Externa: a (re)produção da ideologia puritana e a construção da identidade nacional nas práticas discursivas da política externa norte-americana. $334 \mathrm{f}$. Tese (Doutorado em Ciência Política) - Faculdade de Filosofia, Letras e Ciências Humanas, Universidade de São Paulo, São Paulo, 2010.

SAUSSURE, Ferdinand de (1945). Curso de Lingüística General. Buenos Aires: Losada, 1945 (original francês publicado em 1916).

SEARLE, John (1968). "Austin on locutionary and illocutionary acts". The Philosophical Review, v. 77, n. 4, p. 405-24, Oct. 1968.

."What is a speech act?" (1983). In: GIGLIOGLI, Pier Paulo (ed.). Language and social context: selected writings. New York: Penguin Books (primeira edição de 1972).

TOWNSHEND,Jules (2004). "Laclau and Mouffe's Hegemonic Project: The Story so Far". In: Political Studies, vol 52, 269-288.

TORFING, Jacob. (2005), "Discourse Theory: achievements, arguments, and challenges". In: Discourse Theory in European Politics: Identity, Policy and Governance. HOWARTH, David; TORFING, Jacob. London: Routledge.

VILLA, Rafael Duarte (2008). "Segurança internacional e normatividade: é o liberalismo o elo perdido dos critical security studies?". In: Lua Nova, n. 73, p. 95-122, 2008.

(2007) Quatro teses sobre a política de segurança dos Estados Unidos para a América do Sul. Tese (Livre-docência em Ciência Política) - Faculdade de Filosofia, Letras e Ciências Humanas, Universidade de São Paulo, São Paulo.

(1999) Da crise do realismo à segurança global multidimensional. São Paulo: 
Annablume, 1999.

WALTZ, Kenneth (1979). Theory of International Politics. New York: McGraw-Hill.

WENDT, Alexander (1992). "Anarchy is what states make of it: the social construction of power politics”. International Organization, v. 46, n. 2, Spring 1992.

WODAK, R. (2009). The Discourse of Politics in Action: Politics as usual. London: Palgrave.

ZEHFUSS, Maja (2001). "Constructivism and identity: a dangerous liaison". European Journal of International Relations, v. 7, n. 3, p. 315-48, 2001.

Constructivism in International Relations: the politics of reality. Cambridge: Cambridge University Press, 2002. 


\title{
Artigo II: A macrossecuritização da Guerra ao Terror nos discursos de Brasil, Colômbia e Venezuela na ONU (2002-2006)
}

\section{Resumo}

Neste artigo, volta-se à análise dos discursos dos chefes de Estado de Brasil, Colômbia e Venezuela proferidos na abertura das Sessões Plenárias da Assembleia Geral das Nações Unidas (2002-2006), para mapear os processos linguísticos e argumentativos textuais que indiquem a macrossecuritização da ameaça terrorista no nível do discurso (ato de fala). Assumidos os preceitos teóricos e metodológicos da Escola de Copenhague e da Análise Crítica do Discurso, identificam-se, na amostra, os fenômenos linguísticos de modalização, frames e intertextualidade e as estratégias argumentativas e retóricas predominantes nos discursos dos representantes daqueles países. Ao final, conclui-se que os governos de Colômbia e Venezuela macrossecuritizaram o terrorismo no nível do discurso, enquanto o governo brasileiro buscou reverter a tendência de macrossecuritização do tema.

\begin{abstract}
In this article, we turned to the analysis of the speeches of the heads of state of Brazil, Colombia and Venezuela in the opening of the Plenary Session of the General Assembly of the United Nations (2002-2006) to map the linguistic and textual argumentative processes that indicate the macrosecuritisation of the terrorist threat at the discursive level (speech act). Assuming the theoretical and methodological principles of the Copenhagen School and Critical Discourse Analysis, we identified, in the sample, the linguistic phenomena of modalization, frames and intertextuality, and the argumentative and rhetorical strategies prevalent in the speeches of representatives of these countries. Finally, we concluded that the governments of Colombia, Venezuela macrosecuritised terrorism at the level of discourse, while Brazil's government sought to " de-macrosecuritise" the topic.
\end{abstract}


"As palavras têm significados e consequências"

Oliveiros S. Ferreira, durante aula da disciplina Teoria da Hegemonia, ministrada em curso de Pós-graduação da FFLCH-USP, em 2013.

\section{Introdução}

Este artigo tem como intuito analisar, nos discursos de três presidentes sulamericanos - Lula, Uribe e Chávez e seus representantes -, proferidos na Sessão Plenária da Assembleia Geral das Nações Unidas (AGNU), entre 2002 e $2006{ }^{19}$, a articulação do terrorismo como ameaça de segurança no contexto da Guerra ao Terror, declarada pelo governo norte-americano de George W. Bush após os ataques terroristas ao World Trade Center, em 2001. Tem-se como ponto de partida para esta pesquisa a hipótese de Barry Buzan e Ole Waever (2008) de que o Governo Bush haja tentado macrossecuritizar a Guerra ao Terror em escala mundial, de maneira semelhante à que ocorreu à ameaça comunista nos anos da Guerra Fria (ou seja, ameaça articulada no nível sistêmico e incorporada pelos atores nos demais níveis).

Levadas em conta as definições teóricas e metodológicas da Escola de Copenhague - de que não há temas "naturais de segurança" e de que o processo de securitização se dá a partir de ato de fala que articula objeto referente como ameaça de segurança - e da Análise Crítica do Discurso (ACD), que entende que a linguagem e as demais práticas sociais são co-construídas, procura-se, neste trabalho, identificar a articulação de "terrorismo" nos discursos selecionados, a fim de responder à seguinte pergunta: há elementos que possam apontar para a macrossecuritização da ameaça terrorista no nível discursivo e, por conseguinte, justificar ações de caráter excepcional no âmbito político? Assim, procura-se mapear a argumentação do terrorismo nos discursos dos chefes de Estado, que, ao discursar na ONU, se dirigem aos atores de todos os níveis de análise propostos por Buzan e Waever (2003): o doméstico, o regional e o sistêmico.

Em continuidade da discussão apresentada no artigo anterior, para que seja

\footnotetext{
${ }^{19}$ No caso brasileiro, serão analisados os discursos de 2003-2006, já que Lula foi eleito em 2002 e tomou posse em 2003.
} 
possível acessar as diferentes concepções do termo terrorismo no discurso, este artigo é dividido em três seções. 1) Na primeira, justifica-se a escolha da amostra (discursos proferidos pelos representantes de três países da América do Sul, durante as sessões plenárias da Assembleia Geral das Nações Unidas ocorridas entre 2002 e 2006), de forma a enquadrá-la no aparato metodológico proposto, explicitando-se as conveniências e as inconveniências da escolha, bem como os desafios da tarefa que se propõe levar a cabo. Na mesma seção, apresenta-se breve discussão dos fenômenos linguístico-discursivos analisados, a saber, a modalização, a intertextualidade que em conjunto estratégias retóricas (o lógos, o éthos e o páthos) constituem o processo de argumentação (ato de fala ilocutório) e a persuasão (ato de fala perlocutório).

Estabelecido o corpus e a metodologia de análise, 2) apresentam-se, na segunda seção, os principais argumentos usados na Guerra ao Terror, a partir da Doutrina de Segurança Nacional dos Estados Unidos de 2002 (National Security Strategy, NSS 2002, sigla em inglês adotada daqui em diante), conhecida como Doutrina Bush, seguidos por breve panorama histórico das relações da Superpotência com a América do Sul. Finalmente, na terceira seção, 3) volta-se para a análise dos discursos de Brasil, Colômbia e Venezuela, levando-se em consideração o contexto interno e o contexto externo desses países, aspecto fundamental para a compreensão da macrossecuritização de acordo com os preceitos da ACD.

Este trabalho pretende mapear os processos de argumentação e apresentar as lógicas internas dos discursos no processo de securitização, ressaltando-se a natureza dos argumentos. Trata-se, portanto, de análise cujo objeto é o Discurso (com d maiúsculo para indicar a prática social pela qual a linguagem é utilizada para transmitir ideias e engajar identidades e ações) e cujo objetivo é identificar e ressaltar o processo de construção de sentido nos discursos (com d minúsculo para o "discurso" que remete aos gêneros discursivos) ${ }^{20}$ dos três chefes de Estado. Não se busca, de maneira alguma, tecer julgamentos de valor, da veracidade ou da falsidade dos argumentos apresentados, tampouco advogar a favor de uma das posições dos chefes de Estado. Também, não se pretende avaliar o resultado desses discursos no âmbito extradiscursivo.

\footnotetext{
${ }^{20}$ A utilização de Discurso e discurso como forma de desambiguação do termo comum para dois objetos diferentes foi proposta por LEE (2011, p. 202).
} 


\section{Justificativa da amostra e procedimentos de análise}

\subsection{Construção do problema e desafios}

Apesar da disseminada noção de que a América do Sul seja zona de paz (TAVARES, 2014; MILLER, 2007), livre de guerras interestatais e alvo improvável de atentados terroristas aos moldes dos ocorridos nos Estados Unidos em 2001, na Indonésia em 2002, na Espanha em 2004, e na Inglaterra em 2005, a discussão da ameaça terrorista foi incorporada pelos países da região, não apenas para prestar condolências às populações e países atingidos, mas como parte do Discurso na construção das narrativas referentes a questões domésticas. Como escreveu o jornalista Gilberto de Mello Kujawski em editorial do jornal O Estado de São Paulo de março de $2005^{21}$, no qual critica as medidas adotadas pelo governo americano na Guerra ao Terror,

"Depois que a maior potência econômica e militar foi atingida no âmago, o terrorismo ameaça, realmente, cada metro quadrado habitado pelo homem. $\mathrm{O}$ alvo do terrorismo, agora, não é esta ou aquela parte do mundo, é o próprio mundo".

Longe de ser fenômeno novo, o terrorismo é objeto de discussões, estudado há décadas, que se intensificou no episódio de 11 de setembro. Pouco consenso, porém, foi alcançado no que diz respeito tanto à sua definição e a seus aspectos teóricos ainda não existe uma definição comum para terrorismo (LEANDRO, 2005; HOFFMAN, 2006) - quanto a seus aspectos práticos - as políticas de combate ao terrorismo são alvos de intensa crítica, principalmente em relação aos métodos aplicados pelos governos.

Balanço das medidas adotas nos últimos anos, no âmbito da Guerra ao Terror, principalmente as que empregam o poder duro (NYE, 2002) - como as guerras no Afeganistão, as guerras no Iraque e os ataques conduzidos por drones -, da alta capacidade de recrutamento, da brutalidade dos métodos e do extremismo do Estado Islâmico, do Boko Haram, da Al Qaeda e dos partidários dessas redes ou "lobos

\footnotetext{
${ }^{21}$ Disponível em: http://acervo.estadao.com.br/pagina/\#!/20050303-40679-spo-2-opi-a2not/busca/Brasil+contra.
} 
solitários", que levam a mensagem desses grupos das regiões remotas do Oriente Médio e da África a Paris, Copenhague, Ottawa, Melborne, sugere a resposta à questão que o ex-secretário de Estado dos Estados Unidos, Donald Rumsfeld (2013), formulou nos anos de governo: "com nossas ações estamos contribuindo para combater o terrorismo ou para criar mais terroristas?"

A percepção da natureza do combate ao terrorismo e ao próprio inimigo é um dos principais traços distintivos da Guerra ao Terror de Bush. Nesta, a insistência no caráter assimétrico da ameaça, advinda de grupos transnacionais, ilegítimos, da falência do Estado, das "novas guerras" (KALDOR, 2007), da associação dos rogue states com armas de destruição em massa, sugere que o inimigo esteja em todo e qualquer lugar. Por isso, na visão norte-americana, o combate ao terrorismo não deveria restringir-se aos países diretamente ligados ao problema, mas deveria estender-se a todos os países, inserindo-se assim a "urgência" do tema na pauta internacional.

O diagnóstico de Kujawski no editorial de O Estado, de certa maneira, antecipa a discussão apresentada por Buzan e Waever (2008) a respeito das macrossecuritizações, isso é, a articulação de objeto de referência como ameaça no nível sistêmico, que por sua vez incita securitizações nos níveis inferiores de análise (sub-regional, regional e doméstico - este último, objeto de estudo desta análise). Afinal, a "ameaça terrorista" continua a impor grandes desafios à comunidade internacional, havendo passado mais de uma década do ataque de 11 de setembro.

Autores como Hoffman (2006), sugerem que um dos principais obstáculos no combate ao terrorismo esteja, justamente, na dificuldade em definir aquilo que se busca combater. Uma das concepções mais "estritas" do problema é aquela que define terrorismo como "método" que emprega violência física deliberada e indiscriminada, estabelece sensação de vulnerabilidade a fim de obter ganhos políticos. Na literatura ocidental, o termo ganhou, porém, sentidos mais amplos, que incorporam imagens e emoções específicas, como o mal, o medo, o terror e a selvageria. No caso da "Guerra ao Terror", como o próprio nome estabelece, o "inimigo" identificado é, na verdade, uma emoção: o terror (JARVIS, 2009).

Para demonstrar a dificuldade da definição de terrorismo, Bruce Hoffman, em Inside Terrorism (2006), recorre a exemplos históricos para identificar as diferentes 
concepções de "terrorismo" ao longo dos anos. Afirma que muitos obstáculos na definição do termo podem ser explicados por dois fatores principais: as contínuas mudanças na interpretação do terrorismo pelos atores e as dificuldades em distinguir o terrorismo a partir de outras formas de violência. ${ }^{22}$

Em primeiro lugar, sugere o autor, o significado de terrorismo tem mudado constantemente desde que a palavra foi empregada pela primeira vez, segundo ele durante a Revolução Francesa, para denotar o método utilizado pelo povo para derrotar o usurpador, a Monarquia Absolutista. A partir de então, o terrorismo oscilou entre método utilizado por indivíduos (como na Primeira Guerra Mundial, segundo o autor) e método utilizado por Estados (como na Alemanha nazista e na URSS de Stalin), para finalmente fazer denotar a mistura de técnicas e de ideologias empregadas por atores não-estatais após o fim da Guerra Fria. Em segundo lugar, a dificuldade de definição decorre do grande escopo dos crimes identificados como "terrorismo", que contêm elementos de violência subnacional, guerrilha e crimes de guerra regulares, permitindo que o terrorismo varie dependendo das interpretações e dos interesses de quem o define. Finalmente, Hoffman conclui que o sufixo -ismo é crucial para compreender o fenômeno, independentemente das interpretações divergentes dadas a ele, porque esse sufixo explicitaria o caráter político dos "atos terroristas". Segundo o autor, o terrorismo é essencialmente um tipo de violência politicamente motivada, que visa a provocar mudanças políticas por meio da criação e da exploração deliberada do medo.

Embora identifique, com êxito, as variações gerais no significado de terrorismo, Hoffman não se propõe a explicar por que essas variações se configuraram nem a definir quem eram os atores que estavam por trás dos enquadramentos ou modelos, também conhecidos por frames (conceito que será explicado adiante). Karen A. Feste (2010) trata a questão dos frames do terrorismo nas técnicas de negociação, com o intuito de avaliar as diferentes políticas adotadas nas ações contra o terrorismo. Em Terminar o Terrorismo, examina como as narrativas do conflito podem contribuir para exacerbar crises, ao invés de resolvê-las. Com base em orientações cognitivas e teorias avançadas de negociação, Feste examina diferentes políticas e estratégias adotadas após ataques terroristas, movidos por diferentes pretextos (revolução

\footnotetext{
${ }^{22}$ Para a discussão, na mídia, sobre a falta de definição do termo terrorismo nas convenções da ONU, ver: http://acervo.estadao.com.br/pagina/\#!/20050918-40878-spo-3-edi-a3-not/busca/contra+terrorismo (último acesso: 1.5.2015).
} 
marxista, reclamações segregacionistas e confrontos religiosos), durante a Guerra Fria.

A fim de compreender as circunstâncias em que os atores decidem negociar, Feste analisa diferentes processos cognitivos com base nos quais cada lado se apoiou para enquadrar o adversário, e as possíveis rotas de ação que esses atores poderiam escolher para maximizar os ganhos almejados. Conclui que os processos de negociação em que os frames emocionais e passionais do adversário são abandonados, dando lugar à avaliação pragmática do conflito e dos jogos de interesses, oferecem maiores oportunidades de êxito, embora pareçam ser a opção preterida pelos atores. Afirma que o fato de o terrorismo colidir com valores morais específicos (cujos alvos são inocentes, espalhando-se o terror) que violariam a identidade, que são a pedra de abóbada da sociedade norte-americana, faz que o governo dos EUA tenda a definir o "terrorista" como inimigo, já que seriam indivíduos irracionais, desumanos, que, por isso, devem ser exterminados, a fim de se preservar a própria identidade e valores.

"Em termos jurídicos e teóricos, existe uma definição aceite consensualmente para o Terrorismo? Não. (...) [Mas,] verdadeiramente, ninguém tem grandes dúvidas sobre o que é um ato terrorista." (LEANDRO: 2004, p 371)

Neste trabalho, explora-se o que os atores entendem por terrorismo e a maneira como negociam a definição do termo no ato de fala que busca a securitização da ameaça terrorista. Se por um lado a definição do fenômeno do terrorismo é controversa, por outro a afirmação de Leandro (2005), na qual faz ele concessão de que, embora não haja definição predominantemente aceita para o termo, "todos nós sabemos o que um ato terrorista é", sugere elemento comum nas efetivamente diversas definições, que reside na memória social dos diferentes grupos. Embora Hoffman atribua a utilização do termo terrorismo à Revolução Francesa, Leandro ( $p$. 369) afirma que a prática está registrada nas escrituras bíblicas. Se comprovada, essa informação poderia reforçar o que se especula ser o elemento comum às diferentes concepções de terrorismo na tradição ocidental: um ato terrorista resulta em sofrimento, suplício, morte de inocentes.

A questão da definição de quem são os combatentes, as vítimas e os motivos que levam à ação violenta e, acima de tudo, a legitimam (o jus in bellum, "justiça no guerrear, e o jus ad bellum, "justiça para guerrear") é o tema escolhido por Walzer 
(2003), ao examinar, nos exemplos históricos, a argumentação moral necessária para que uma Guerra seja considerada "justa". Nardin (2015, p. 3) explica a importância da retórica como elemento essencial nesse processo:

\begin{abstract}
"Arguing about war, like arguing about morals and politics in general, is persuasive and rhetorical, not demonstrative or a matter of proof (Walzer 1987, 32) (...) Because Walzer's aim is ultimately practical - to identify moral principles for use - he is concerned with the present structure of the moral world. His just war theory, in other words, is a slice in time across a slowly changing tradition of just war discourse. That discourse enables arguments that are mutually comprehensible even when their context is different or they contradict one another."
\end{abstract}

De volta a terrorismo, se a ideia do "sofrimento de inocentes" for, de fato, o elemento para que convergem as diversas interpretações do terrorismo e se Leandro estiver correto em reportar a prática do terrorismo aos textos bíblicos (questões que demandariam extensa pesquisa, que estão muito além do escopo deste trabalho), pode-se afirmar que o termo contém grande força retórica. Isso permite a suposição de que a força retórica associada ao momentum trazido pelo ataque de 11 de setembro favoreceria a persuasão da audiência a favor da Guerra ao Terror, fato que, correto ou não, foi percebido e incorporado pela administração de Bush, capaz de convencer a população norte-americana da urgência das políticas propostas por seu governo ${ }^{23}$.

Do mesmo modo, o poder persuasivo e o momentum podem ter influenciado outros governos a instrumentalizar a ameaça terrorista. Para isso, é necessário que se volte, primeiramente, a seus discursos, em especial, aqueles que têm ampla cobertura da mídia. A repercussão das ideias articuladas pelas elites políticas se dá sobretudo pelos meios de comunicação. Aquilo que ganha relevo na mídia tende a ser o que é aceito, pela maioria da população, como a "verdade" ${ }^{4}$. Sabe-se que a mídia desempenha papel importante na ampla naturalização de valores e em sua assimilação ${ }^{25}$, favorecendo-se determinadas interpretações da realidade (BARROS,

\footnotetext{
${ }^{23}$ A aprovação do Governo Bush em 2002 chegou a quase $90 \%$ de acordo com pesquisa de opinião conduzida pelo Gallup, disponível em: http://www.gallup.com/poll/116500/presidential-approval-ratingsgeorge-bush.aspx (último acesso 15.05.2015)

${ }^{24}$ Adiante, a importância da mídia na transmissão de ideias será retomada para justificar o corpus de análise.

${ }^{25}$ Para "Agenda Setting" e a "espiral do silêncio" em teoria de Comunicação ver Hohlfeldt (2001), McCombs (1992). Para a democracia de massas e agenda setting, ver Cobb (1971).
} 
2008).

Ao analisar como reportagens se referem ao terrorismo - de setembro de 2001 a 2006 - no jornal americano US Today, Reese e Lewis (2009) concluíram que notícias e editoriais do período não só interiorizaram os frames propostos pelo governo dos EUA sobre a Guerra ao Terror, mas também tomaram as opções políticas como incontestáveis, naturalizando-as e pressupondo-as como "senso comum". Entender a evolução dos frames é parte fundamental na construção do que é o "senso comum" (van DIJK, 2008) e é de considerável relevância no estudo da segurança, porque ressalta a importância da astúcia retórica nos processos de securitização e de identidade. A mobilização da história, de dados culturais, códigos e frames preexistentes é imprescindível para que os governos possam obter o apoio necessário para mobilizar a ação militar (SMITH, 2005).

Dessa forma, este trabalho objetiva identificar os primeiros passos do processo da securitização, no discurso. Para entender como os atores realizam os atos de fala propiciadores da securitização, é essencial identificar, também, o que entendem por terrorismo. Neste ponto, é necessário ressaltar que este trabalho busca as definições de terrorismo que os autores utilizam para articular o tema nos discursos analisados (não se pretende aqui encontrar ou comparar os documentos oficiais ou as convenções aprovadas referentes ao tema). A definição do terrorismo em cada um dos discursos é essencial para compreender a linha retórica assumida e como ela contribui para o ato de fala, para a securitização.

É por essa razão, também, que os discursos escolhidos para este trabalho foram os discursos proferidos na Assembleia Geral da ONU. Na AGNU, cada representante fala por seu Estado e para a população de seu país. Não só isso: fala para o mundo, em tempo real, em condições de igualdade com os demais atores. Além disso, o tempo limitado dos discursos faz que a escolha dos temas seja a que mais reflita as preocupações/interesses daquele determinado Estado naquele momento. Pela importância política da Sessão Plenária da Assembleia Geral, por seu prestígio, ela é repercutida pelos meios de comunicação e consumida por grande parte da população (que talvez nunca lesse uma doutrina de segurança), o que contribui para que a securitização se complete (ou se realize a perlocução), o que, por sua vez, propicia determinadas medidas políticas e leva à neutralização de conceitos, ou seja, ao 
entendimento do "terrorismo" de que todos sabem. A questão apresentada não é saber se Estados assimilaram a Guerra ao Terror conforme fora articulada pelo Governo Bush, mas como ela foi instrumentalizada pelos demais governos para obter fins políticos.

Quando Buzan e Waever (2008) estudam a macrossecuritização da Guerra ao Terror, para além da delimitação teórica que realizam (já que o conceito deve ser entendido dentro da estrutura da securitização e das teorias dos Complexos Regionais de Segurança), a questão que se levanta é identificar se ela estimulou (ou exacerbou) a securitização da ameaça terrorista aos moldes do que ocorreu à "ameaça comunista" no período da Guerra Fria. Essa ressalva é importante porque na Guerra Fria a ameaça comunista ditou a lógica de securitização de muitos governos e abriu espaço para que os governos instrumentalizassem essa narrativa ao incorporar a ameaça comunista a seus contextos domésticos - fazendo-a servir de justificativa para diversas medidas de exceção, golpes militares, suspensão das liberdades civis etc.

Por extensão, pode-se argumentar que, se as hostilidades da Guerra Fria foram reinterpretadas e incorporadas de maneira a servir às políticas (principalmente a doméstica, mas, também, a externa) dos Estados que incorporam ameaça, a macrossecuritização da guerra ao terrorismo não pressupõe que os demais países securitizem a ameaça terrorista da mesma maneira que os EUA, isso é, valendo-se das mesmas narrativas e interpretações. A partir daí, não seria incorreto afirmar que a macrossecuritização ocorre quando os demais atores se valem da estratégia de combate "urgente" (pressupondo adoção de medidas excepcionais) à ameaça terrorista, para justificar a sobrevivência e a manutenção de seus Estados, por meio de narrativas que podem convergir para a exposta na Doutrina Bush ou dela divergir. Entende-se, então, que seria possível que Estados macrossecuritizassem a Guerra ao Terror ainda que questionando a hegemonia ${ }^{26}$ das concepções norte-americanas sobre o tema.

\footnotetext{
${ }^{26}$ Entendida não apenas em termos de força, mas, sim, como força e consenso. Para completo estudo sobre a Teoria da Hegemonia de Gramsci, ver FERREIRA (1986).
} 


\subsection{Escolha da amostra: os discursos dos presidentes de Brasil, Colômbia e Venezuela na ONU}

A escolha dos três países para o estudo de caso se deve, conforme exposto no artigo anterior, ao fato não só de serem as maiores economias da região, mas também de possuírem daí os maiores contingentes militares (juntamente com a Argentina); justifica-se principalmente pela diversidade das posições políticas dos representantes, Lula, Uribe e Chávez. A Escolha do período de 2002-2006 é que em 2006 foi publicada nova doutrina de segurança nos EUA; dessa forma, o conteúdo dos discursos de 2002 a 2006 estaria inserido no documento de 2002. O segundo passo que fortaleceria a análise seria o cruzamento dos dados obtidos nesses discursos com as doutrinas de segurança e defesa daqueles países; para o propósito deste artigo, preferiu-se, porém, adotar amostra menor e aprofundar a análise, ao invés de amostra maior e mais geral.

A opção pela análise dos discursos dos chefes de Estado para compreender a articulação da Guerra ao Terror também foi feita por Hodges (2011, p. 197), que assim a justifica:

\footnotetext{
"Although the analysis focuses on a narrative told by an individual speaker on specific occasions, the result is to distill from these representative examples the macrolevel discourse about the "war on terror." In this way, the repeated narrations by the president of the United States effectively accumulate into a larger cultural narrative shared by many within the nation (and beyond) - what Bruner (1991) terms "narrative accrual." Importantly, the power of the president (and the story he tells) is, as Gal (1991) says of power more generally: "more than an authoritative voice in decision making; its strongest form may well be the ability to define social reality, to impose visions of the world."
}

Já a escolha dos discursos proferidos na Sessão Plenária da Assembleia Geral da ONU se justifica porque, conforme mencionado anteriormente, neste momento os chefes de Estado se dirigem não apenas a sua audiência interna (seus nacionais), mas também à comunidade internacional como um todo. Segundo Sardenberg (2013, p. 512)

"Como sugere o Professor Paul Kennedy, a Assembleia Geral é o principal órgão deliberativo das Nações Unidas, um verdadeiro 'parlamento da humanidade'. (...) De fato e de direito, a Assembleia Geral é o órgão plenário 
das Nações Unidas, onde todos os seus Estados-membros têm representação permanente e a exercem, por meio do voto individual e unitário, sem recurso a veto $(\ldots)$

É o grande foro ao qual são trazidas todas as questões que interessam à comunidade internacional. Por esse motivo, a Carta não coloca limites à sua competência; pelo contrário, ela a define nos termos mais amplos possíveis para que todos os temas que afetam as relações internacionais sejam incluídos em sua jurisdição. (...) A Assembleia Geral, com seus meios para disseminar ideias, é o órgão que está primordialmente equipado para criar uma opinião pública mundial."

Além disso, o encontro dos chefes de Estado na abertura da Assembleia Geral é o momento que atrai maior atenção da mídia (elemento essencial na transmissão de conceitos, conforme observado acima pelo trabalho de Lewis (2009). Ainda conforme Sardenberg (2013, p. 54),

\begin{abstract}
"O momento em que a Assembleia Geral recebe mais atenção da opinião pública mundial é seu Debate Geral, que geralmente ocorre por três semanas, a partir da última semana de setembro. O evento ganha tanta divulgação que, com frequência, a imprensa o confunde com a própria Assembleia como um todo. Nessa ocasião, um número muito substancial de Chefes de Estado e Governo, assim como Ministros das Relações Exteriores, acorre a Nova York para discursar perante a Assembleia e enunciar suas prioridades para 0 ano que virá, não só nas Nações Unidas, mas na política internacional como um todo. Por exemplo, foi no Debate Geral da $57^{a}$ Assembleia que o Presidente George Bush, dos EUA, manifestou a intenção de invadir o Iraque, o que viria a concretizar-se no ano seguinte. Desde os anos 1950, o Brasil tem o privilégio de fazer o primeiro discurso no Debate Geral, logo após o relatório anual do Secretário-Geral e antes da fala do país anfitrião, os EUA."
\end{abstract}

A opção pela análise dos discursos que esses atores proferiram na abertura da Assembleia Geral da ONU de maneira alguma esgotará o tema, tampouco é suficiente para responder a pergunta sobre a macrossecuritização (para isso, além dos discursos, seria necessário voltar às ações adotadas por aqueles presidentes para saber se a enunciação da ameaça correspondeu a medidas concretas de combate a ela). Ao delimitar o objeto e manter a possível fidelidade à metodologia, é possível que se extraiam indícios de como ocorre a articulação do terrorismo naqueles países, o que por sua vez poderá servir de ponto de partida para análises e de primeiro indício de como o jogo de forças em torno da macrossecuritização é articulado. 


\title{
1.3. Fenômenos de linguagem analisados
}

\begin{abstract}
"En tant que réalisation individuelle, l'énonciation peu se définir par rapport à la langue, comme un procès d'appropriation. Le locuteur s'approprie l'appareil formel de la langue et il énonce sa position de locuteur par des indices spécifiques, d'une part, et au moyen de procédé accessoires, de l'autre." (BENVENISTE, 1970, p. 82)
\end{abstract}

Os fenômenos linguísticos a que este trabalho se volta são as modalizações, a intertextualidade e os frames. Diante dos inúmeros instrumentos disponíveis para o estudo do discursos, a prioridade dada a esses três decorre do fato de que eles são fundamentais para as estratégias retóricas e argumentativas, que estão na base dos fenômenos políticos. A análise dessas últimas se justifica porque, como ato de fala ilocutório, a securitização visa à perlocução, ou seja, ao convencimento.

A modalização é fenômeno de linguagem, conceitual, que permite que se expresse, no ato enunciativo, a posição e comprometimento particular do sujeito em relação àquilo que ele diz e para quem diz. Pelo estudo das modalizações é possível identificar o grau de engajamento do locutor com a mensagem e a participação do interlocutor no processo, permitindo que se identifique uma assunção peculiar de concepções de mundo. Neste trabalho, assume-se a linha proposta por Charaudeau (1992), que identifica três tipos de modalização: a modalização alocutiva, a modalização elocutiva e a modalização delocutiva, definidas a seguir:

"Les Modalités ALLOCUTIVES impliquent locuteur et interlocuteur, et précisent la manière avec laquelle le locuteur impose un Propos à l'interlocuteur." (p. 579);

“Les Modalités ÉLOCUTIVES n'impliquent pas l'interlocuteur dans l'acte locutif. Elles précisent la manière dont le locuteur révèle sa proposition vis-à-vis du Propos qu'il énonce." (p. 599);

“Les Modalités DÉLOCUTIVES sont déliées du locuteur et de l'interlocuteur. Le propos émis existe en soi, et s'impose aux interlocuteurs dans son mode de dire: 'Assertion' ou 'Discours' rapporté." (p. 619). 
A compreensão do enunciado executado pelo sujeito no processo de enunciação é, por sua vez, interpretada pelo interlocutor, que decodifica a mensagem pautando-se naquilo que the foi explicitamente dito, isso é, nas palavras proferidas no ato enunciativo, e no contexto em que este se insere. No processo de comunicação, o locutor assume a capacidade de inferência do interlocutor, para a compreensão daquilo que diz (LEE, 2011). Os processos de inferência são de natureza linguístico-cognitiva e dependem da quantidade de conhecimentos compartilhados entre locutor e alocutário, o que é manifestado pelos modelos ou frames e pelo fenômeno mais amplo da intertextualidade. Koch (2011, p. 23) apresenta o papel fundamental dos frames, figuras cognitivas essenciais no processo de significação:

\begin{abstract}
"Os modelos constituem conjuntos de conhecimentos socioculturalmente determinados e vivencialmente adquiridos, que contêm tanto conhecimento sobre cenas, situações, e eventos, como conhecimentos procedurais sobre como agir em situações particulares e realizar atividades específicas. São, inicialmente, particulares (já que resultam das experiências do dia-a-dia), determinados espaço-temporalmente e, por isso, estocados na memória episódica. Após uma série de experiências do mesmo tipo, tais modelos vão-se tornando generalizados, com abstração das circunstâncias particulares, específicas (van Dijk:1989), e, quando similares aos dos demais membros de um grupo, passam a fazer parte da memória enciclopédica ou semântica".
\end{abstract}

Esses modelos compõem o fenômeno mais amplo da intertextualidade, que se manifesta nos discursos para engatilhar a conexão a outros textos (entendidos como palavras ditas e escritas anteriormente) que se pressupõe que sejam compartilhados e estejam presentes no imaginário social da audiência para a qual o sujeito enunciatário se dirige. O exame do fenômeno da intertextualidade é fundamental na Análise do Discurso Político, porque, em última instância, permite que se identifiquem as diferentes visões de mundo, os diferentes valores, condutas e normas, que são transmitidos, negociados ou rechaçados no discurso.

"The notion of intertextuality - a term associated with Kristeva's (1980)
articulation of Bakhtin's (1981, 1986) dialogism and widely taken up by
sociocultural linguists (note, for example, A. L. Becker's role in introducing
intertextuality to sociolinguistics as well as its influential use by Richard Bauman
and Charles Briggs within linguistic anthropology) - is useful for the analysis of
political discourse because it emphasizes the connections across multiple
discursive encounters where issues are formulated and contested. Intertextual
connections involve a process whereby a given piece of discourse is lifted from 
one setting - that is, it is decontextualized - and is inserted into another setting where it is recontextualized (Bauman and Briggs:[?] 1990). When a piece of discourse is moved from one context to another, it carries along aspects of the earlier context; but it is also transformed in the new context." (HODGES: 2011 , p. 6)

Nos discursos argumentativos, como é o caso do discurso político, o locutor busca convencer o interlocutor a assumir determinado ponto de vista ou agir de determinada maneira. No processo de securitização, o ato de fala (ilocutório) completa-se somente quando há a adesão da audiência (perlocução) à ideia de que um objeto de referência seja ameaça de segurança. O convencimento por meio da articulação da linguagem é o objeto de estudo da Retórica, que Aristóteles (1995, p. 522) admite ser:

\begin{abstract}
"Let us, then, take rhetoric to be the capacity to observe the available mean of persuasion (...) rhetoric seems to be able to observe what is persuasive on any question presented to it (...)".
\end{abstract}

Pela Retórica o sujeito falante busca persuadir. A persuasão, por sua vez, depende do convencimento dos ouvintes, quando o discurso desperta, neles, sentimentos de convicção."People are convinced through the speech itself whenever we prove what is true or appears true from whatever is persuasive on each topic" (ARISTÓTELES, 1995, p. 523)

Para isso, é necessário que a argumentação mobilize três mecanismos argumentativos: o lógos, o éthos e o páthos ${ }^{27}$, presentes em todas as argumentações. Quando uma argumentação se sustenta predominantemente no lógos, o locutor explora a articulação racional da argumentação, que se apresenta no encadeamento de ideias "racionais" e na consistência interna da mensagem. A argumentação sustentada predominantemente no éthos (entendido em termos retóricos, não como ramo da Filosofia) evoca a credibilidade do enunciador, do sujeito que fala ou escreve, em relação à mensagem. $\mathrm{Na}$ argumentação predominantemente baseada no páthos, o sujeito argumentador recorre às emoções da audiência, aos aspectos subjetivos desta.

A escolha da modalização está intimamente ligada ao tipo de argumento

\footnotetext{
${ }^{27}$ Os termos lógos, éthos e páthos devem ser entendidos, neste trabalho, de acordo com as definições propostas por Aristóteles.
} 
predominante (éthos, lógos ou páthos), à natureza da argumentação que o sujeito argumentador pretende traçar. O uso de modalização delocutiva corresponde ao percurso lógico, pela neutralização de ambos os sujeitos, argumentador e argumentatário, ao privilegiar a mensagem; à modalização elocutiva corresponde o ético; à modalização alocutiva está associado o recurso patético, como explica Maruxo (2011, p. ):

\begin{abstract}
"Se no ético o sujeito argumentador busca projetar uma imagem de si mesmo para estabelecer a confiança com o sujeito argumentatário (...) no patético buscará envolver o argumentatário projetando uma imagem com que este se identifique, mesmo que isso resulte numa forma de encenação enunciativa (...). Essa projeção enunciativa de natureza alocutiva pode despertar a adesão do sujeito argumentatário às teses e aos argumentos logicamente formulados, expressos pelo percurso argumentativo lógico, por meio de identificação empática do argumentatário com a imagem que o sujeito argumentador projeta dele no texto.".
\end{abstract}

Os exemplos de uso dos fenômenos vistos, acompanhados de discussão pormenorizada de como estes operam na prática (ou seja, nos enunciados realizados), serão apresentados no item 3.

\title{
2. A Guerra Global ao Terrorismo: formulação argumentativa e diálogo com a América Latina
}

A este trabalho não interessa o juízo de valor da Guerra ao Terror. Busca-se aqui apresentar os argumentos que justifiquem a análise da macrossecuritização do combate ativo ao terrorismo (ou seja, a macrossecuritização da Guerra ao Terror), porque o texto apresenta perspectiva inédita na interpretação dos fenômenos terrorismo, falência do Estado e armas de destruição em massa), propondo reinterpretação dos valores normativos do próprio sistema internacional, com o qual os discursos de Lula, Uribe e Chávez dialogam, tentando negociar em duas frentes: para seu público interno e para sua influência no sistema internacional. Em última instância, esse processo de negociação de visões de mundo está na base de qualquer macrossecuritização e remete-se às noções de hegemonia.

Para tal, optou-se por breve exposição da Doutrina Bush, que é o marco teórico 
da Guerra ao Terror e, apesar de ser documento oficial (escrito), consiste na compilação de discursos proferidos pelo presidente norte-americano após o 11 de setembro.

\title{
2.1. A Doutrina Bush: o marco teórico da Guerra ao Terror
}

\begin{abstract}
"Truth is not simply an object external to social interaction; but rather, a form of knowledge emergent from that interaction. In this book, I highlight the textual and intertextual nature of the process that makes it possible for the powerful discursive formation that is the Bush 'War on Terror' Narrative to gain significant traction in public understandings since 9/11. By examining the formation and circulation of such powerful narratives, we gain insight into the social effects that text production and circulation can have in sustaining regimes of truth and producing real world actions." (HODGES, 2011, p. 4)
\end{abstract}

No ano de 2002, o presidente George Bush divulgou a Doutrina de Segurança Estratégica de seu governo, que gerou extensa discussão no meio acadêmico sobre os rumos que a política externa dos Estados Unidos tomaria sob a égide da "Doutrina Bush". As Doutrinas de Segurança Estratégicas são, tradicionalmente, publicadas pelos chefes do executivo do país norte-americano e têm como finalidade elencar as ameaças à segurança nacional dos Estados Unidos, bem como as estratégias de cunho político e militar para assegurar a defesa e integridade do povo e do território norte-americanos. A "Doutrina Bush" identifica como as principais ameaças à segurança dos Estados Unidos (e do mundo) o resultado da combinação: terrorismo, os estados falidos ${ }^{28}$ e as armas de destruição em massa (REITER, 2006) O documento, que data de 2002, foi amplamente discutido por especialistas, já que muitos consideram que a principal estratégia que traz a Guerra de Preempção ${ }^{29}$ (a que os críticos chamaram Guerra Preventiva) configura grave violação do direto internacional vigente (BROWNLIE, 2003).

Ao longo do texto, a NSS 2002 é constantemente justificada evocando-se palavras como "legitimidade", "legalidade" e "justiça". Tenta-se convencer a comunidade internacional de que as circunstâncias mudaram (assimetria de atores que

\footnotetext{
${ }^{28}$ Para a discussão sobre a definição de Rogue States ver Litwak (2000)

${ }^{29}$ Para as diferenças entre Guerra de Prevenção e Guerra de Preempção no Direito Internacional ver Brownlie (2003, p 702). Para a definição de Agressão e discussão sobre o artigo 51 da carta da ONU ver Velasco (2005).
} 
não gozam de personalidade jurídica em Direito Internacional, novas ameaças, perda da capacidade de dissuasão), fato que poria o Estado em risco. O texto deixa explícito que os Estados Unidos da América não medirão esforços para combater as ameaças terroristas antes de elas atingirem as fronteiras do país, mesmo que para isso tenham de agir de maneira unilateral Isso porque as novas ameaças abrangeriam a prática de terrorismo suicida e existência Estadas Páreas, que não levariam em conta o risco de não cooperação em casos de estratégias dissuasivas (GADDIS, 2004; KRAUTHAMMER, 2003; PODHORETZ 2003). Logo na abertura do documento, o presidente Bush expõe os três pilares que, segundo ele, sempre nortearam a tradição norte-americana nas relações internacionais: direitos humanos, liberdade política e liberdade econômica. Ao expor tais princípios, Bush afirma que: "In keeping with our heritage and principles, we do not use our strength to press for unilateral advantages".

Estabelecido isso, afirma-se ser obrigação moral dos Estados Unidos lutar contra "terroristas e tiranos". Há no texto clara referência à particularidade das circunstâncias e dos atores encontrados no século XXI, que justificaria a adoção de medidas preventivas, já que "Enemies are not great armies (...) Shadowy networks of individuals can bring great chaos and suffering to our shores for last than it cost to purchase a single tank" (NSS 2002). O texto sugere que contra essas novas ameaças, que guardariam caráter "excepcional", justificar-se-ia a utilização de todos os tipos de estratégia e afirma que "It is a global enterprise of uncertain duration".

Apresentam-se, na introdução, os pontos essenciais da doutrina. O primeiro diz respeito à afirmação de que os norte-americanos estariam seguindo tradição de longa data ao apoiar as liberdades. O segundo diz respeito à mudança de circunstâncias: a ideia presente no documento é que os americanos não poderiam adotar contra os grupos terroristas as estratégias usadas contra exércitos regulares (o rebus sic stantibus permitiria, pela mudança de circunstâncias, suspender o pacta sunt servanda?). Outro ponto é a divisão polar do mundo, afirmando-se que aqueles que não estivessem a favor dos EUA seriam os "inimigos", que também seriam os inimigos da civilização e da moral: "The allies of terror are the enemies of civilization", espécie de autoproclamação dos Estados Unidos como "guardião" da civilização (NSS 2002). 
"Today our enemies have seen the results of what civilized nations can, and will, do against regimes that harbor, support, and use terrorism to achieve their political goals. Afghanistan has been liberated; coalition forces continue to hunt down the Taliban and al-Qaida. But it is not only this battlefield on which we will engage terrorists. Thousands of trained terrorists remain at large with cells in North America, South America, Europe, Africa, the Middle East, and across Asia." (NATIONAL SECURITY SETRATEGY OF THE UNITED STATES, 2002)

Em seguida, é levantada a questão da ação antecipatória, o agir antes que a ameaça se concretize. Consta no documento a afirmação de que, na atualidade, o maior perigo para os norte-americanos seja a associação dos seguintes elementos: terrorismo, tecnologia e radicalismo. Combinados, esses três elementos trariam grande insegurança aos americanos e justificariam a antecipação das ações defensivas, como escrito:

\begin{abstract}
"As a matter of common sense and self defense, America will act against such emerging threats before they are fully formed. We cannot defend America and our friends by hoping for the Best. So we do must be prepared to defeat our enemies' plans using the best intelligence and proceeding with deliberation. History will judge harshly those who saw this coming danger but failed to act. In the new world we have entered, the only path to peace and security is the path of action." (Idem)
\end{abstract}

Por essa afirmação, podem-se verificar alguns elementos usados reiteradamente nas discussões que precederam a invasão de março de 2003. Considera-se o ataque como inevitável, ainda que não realizado e longe de se concretizar, já que, para os formuladores da doutrina, a discussão não estaria restrita ao campo político, mas, sim, seria extensiva a questões morais e de valores. Em se partindo dessa lógica, não haveria como negociar com os terroristas, e o ataque contra os norte-americanos, mesmo que não planejado, seria iminente.

Para comprovar que as circunstâncias seriam inéditas, afirmam que as potências, que outrora estiveram envolvidas em grandes disputas, encontram-se "no mesmo lado", unidas pelo iminente perigo de caos trazido pelos terroristas. Ou seja: a guerra simétrica deixa de ser a prioridade de segurança dos EUA. Há no texto contraposição entre países de tradição democrática, "a melhor opção para paz", os Rogue States (Estados Párias), que seriam caracterizados por "poverty, week institutions and corruption" e grupos terroristas que, caso adquiririssem armas de destruição em massa, poriam em risco todos os países "livres", o que, segundo o documento, traria a 
responsabilidade aos americanos de "liderar uma grande missão".

\title{
3. O Terrorismo nos discursos sul-americanos na ONU: estudo de caso
}

\begin{abstract}
"Parts of Latin America confront regional conflict, especially arising from the violence of drug cartels and their accomplices. This conflict and unrestrained narcotics trafficking could imperil the health and security of the United States. Therefore we have developed an active strategy to help the Andean nations adjust their economies, enforce their laws, defeat terrorist organizations, and cut off the supply of drugs, while-as important-we work to reduce the demand for drugs in our own country." (NATIONAL SECURITY SETRATEGY OF THE UNITED STATES, 2002)
\end{abstract}

Como mencionado no primeiro artigo, a relação dos países do Complexo Regional Sul-americano com a Superpotência oscila entre amizade e desconfiança. Com o final da Guerra Fria, os Estados Unidos adotaram para a América Latina linhas de política externa que podem ser resumidas em três aspectos essenciais, identificados por Villa (2006): i) a consolidação da democracia; ii) o comércio (principalmente voltado para a adoção de área de livre-comércio nas Américas); iii) a segurança.

$\mathrm{Na}$ área de segurança, a agenda norte-americana apresentou tendência à ampliação do processo de securitização para a região, buscando a incorporação de temas na pauta de segurança, o que justificaria o tratamento diferenciado de questões que antes não eram tidas como fundamentais para a "sobrevivência do Estado" (MESSARI: 2004; VILLA, 2006); isso se traduziu na pressão para o emprego de contingentes militares para exercer papéis de polícia. Nessa lógica, a Guerra às Drogas - isso é, o combate ao narcotráfico, que teve início no Governo Nixon, se popularizou no Governo Bush pai e atingiu o clímax no Governo Clinton (RICCARDELLI, 1994), que firmou com o presidente colombiano Andrés Prestana o Plano Colômbia, em 1999 ocupou posição central na política externa dos Estados Unidos para a região

A crescente presença norte-americana na América do Sul, em grande medida sustentada no argumento do combate ao narcotráfico, ganhou novos contornos com o ataque de 11 de setembro. Antes do ataque, o Governo Bush havia manifestado intenção de ampliar as relações com os países da América Latina, que eram tidos como "a menina dos olhos de seu governo". Após o ataque, no entanto, o foco da política 
externa norte-americana voltou-se para o Oriente Médio. Se por um lado a América Latina, em geral, e a América do Sul, em especial, deixaram de ocupar posição privilegiada na agenda norte-americana, por outro a associação da "ameaça terrorista" ao narcotráfico, pela administração de Bush, inseriu a região no mapa da Guerra ao Terror.

\begin{abstract}
"Congress designated the U.S Department of Defense as the "single lead agency" for the detection and monitoring of illicit drugs(Youngers, 2006:74) Hence, the US Southern Command (SouthCom) - Unified Combatant Command of the Department of Defense responsible for providing contingency planning and operations in Central and South America - embraced the war on drugs as means of not only maintaining, but expanding its role, influence and presence in the region. With September 11 and consequent political integration of the concepts of drug trafficking and terrorism, the role of SouthCom was consolidated. Not long after September 11, the US attorney general, John Ashcroft, declared, 'terrorism and drugs go together like rats and the bubonic plague. They thrive in the same conditions, support each other and feed each other'." (TAVARES: 2014, p. 22-3)
\end{abstract}

Embora não houvesse indícios de atividades terroristas (de viés fundamentalista islâmico) na América do Sul nem a percepção de que o continente estaria na rota dos radicais, o governo dos EUA se apressou a identificar os elos entre o narcotráfico e grupos rebeldes/terroristas ao redor do mundo. A hipótese de que as atividades terroristas se valiam do narcotráfico como uma das principais formas de financiamento esteve no centro das discussões entre o governo Bush, que contemplou essa ligação, e os governos da região que se opunham a ela ${ }^{30}$. Documentos revelaram que, pouco após o 11 de setembro, cogitou-se a hipótese de ação armada na América do Sul, visando à eliminação das fontes aí financiadoras do terrorismo islâmico, em regiões como a tríplice fronteira $^{31}$ (HUDSON, 2003; FARAH, 2007; AMARAL, 2007). A desconfiança dos governos sul-americanos, como o do Brasil e o da Venezuela, de que os EUA usassem o pretexto do terrorismo para aumentar a influência militar na região foi uma das grandes fontes de atrito entre os países e a Superpotência: aqueles buscavam política externa mais autônoma, de forma a reduzir na região a influência dos norte-americanos, posição que pode ser observada nos discursos de Lula e Chávez na ONU.

Como se verá a seguir, o fato de os três países da amostra apresentarem

\footnotetext{
${ }^{30}$ Ver matéria da CNN “Terror na tríplice fronteira” http://acervo.estadao.com.br/pagina/\#!/2002110839833-nac-14-int-a14-not/busca/terrorismo

${ }^{31}$ Ver as matérias publicadas no jornal O Estado de São Paulo: "Brasil nega haver terrorismo na tríplice fronteira" (09.11.2002), disponível em http://acervo.estadao.com.br/pagina/\#!/20021109-39834-spo-23int-a28-not/busca/contra+terrorismo
} 
conjunturas internas e interesses bastante peculiares e heterogêneos entre si exerce grande impacto na postura adotada pelos governos daqueles países em face da construção argumentativa e das linhas de ação adotas pelo Governo Bush. A mediação entre as discussões que ocorrem no nível sistêmico e as que ocorrem no nível regional e, principalmente, no nível doméstico é fundamental para compreender o objeto dos discursos e a maneira como cada um dos presidentes sustenta seus argumentos. Dessa forma, é importante ressaltar que os discursos a seguir, por ser destinados a audiências diversas, pressupõem intertextualidades de diversos níveis, que, por sua vez, influenciam as diferentes maneiras como cada um deles é recebido pelos interlocutores. As múltiplas vozes que ressoam nesses discursos carregam evidências de como a articulação da ameaça terrorista foi renegociada, contestada e trazida à conjuntura doméstica de cada ator. Destarte, na assunção de que contexto e linguagem estão em intrínseca relação, à análise da amostra antecede breve apresentação da conjuntura interna de cada um dos países.

\subsection{Brasil}

\section{"Erradicar a fome é um imperativo moral e político"}

Lula, em discurso na $58^{\mathrm{a}}$ Abertura da AGNU, em Nova lorque

$\mathrm{O}$ ataque terrorista de 11 de setembro se deu no penúltimo ano do governo de Fernando Henrique Cardoso, que esteve à frente do governo por dois mandatos. Em decorrência do ataque, o Governo Cardoso invocou o Tratado Interamericano de Assistência Recíproca, que pressupõe que ataque a um dos membros é ataque a todos $^{32}$. As semanas que se sucederam ao atentado foram marcadas por grande solidariedade e empatia para com o povo e o governo norte-americanos. Para reforçar essa solidariedade, o Presidente Fernando Henrique Cardoso se endereçou, em 2001, pela primeira vez ao longo dos mandatos, à comunidade internacional na abertura da Assembleia Geral da ONU.

\footnotetext{
${ }^{32}$ Para discussão pormenorizada sobre o TIAR e a participação do Brasil na Conferência de Punta Del Leste, ver FRANCHINI NETO (2005).
} 
Se no plano externo o Governo FHC foi capaz de manter boas relações com os Estados Unidos enquanto buscava maior integração sul-americana (cuja prioridade se deu no MERCOSUL), no plano interno a ênfase dada às reformas políticas e macroeconômicas de arrocho de gastos e controle da inflação, com privatizações e liberação do câmbio, incidiu na popularidade do presidente, que não conseguiu eleger seu sucessor. Com a eleição de Luís Inácio Lula da Silva, a bandeira dos "pobres" e excluídos, em 2002, foi articulada com a ruptura de anos de exploração dos estratos mais baixos (e majoritários) da população pelas "elites governantes", que se perpetuavam no poder desde os tempos coloniais.

Quando Lula assumiu o primeiro mandato, em primeiro de janeiro de 2003, pairavam incertezas quanto a condução da política econômica e manutenção das instituições, por um lado, e otimismo quanto a alternância de poder e expectativa de mudanças sociais inclusivas, por outro. Assim, nos primeiros meses de governo, Lula se empenhou em assegurar a confiança dos mercados em sua política econômica e reforçar seu compromisso com instituições democráticas, ao mesmo tempo em que reiterava seu compromisso prioritário com os programas sociais, com foco especial no combate à fome e à miséria. Esses elementos também estiveram presentes na inserção externa do Brasil sob o comando do presidente Lula:

\begin{abstract}
"A ação diplomática do Governo Lula é concebida como instrumento de apoio ao projeto de desenvolvimento social e econômico do País. Mas ela possui, também, uma dimensão humanista, que se projeta na promoção da cooperação internacional para o desenvolvimento e para a paz. Está profundamente enraizada nos interesses e esperanças do povo brasileiro. É nacional, sem deixar de ser internacionalista." (AMORIM: 2004, p. 47)
\end{abstract}

Na política externa, o Brasil aprofundou parcerias com países da África, da Ásia, especificamente do Oriente Médio ${ }^{33}$, e aprofundou as parcerias com a América do Sul, tentando contrabalançar a influência norte-americana na região (OLIVEIRA, 2005). As relações diplomáticas com os Estados Unidos se mantiveram amigáveis, a que o

\footnotetext{
${ }^{33}$ A cúpula América do Sul — Países Árabes, que se constituiu em Brasília, em 2005, gerou diversas críticas e foi fonte de atrito com o governo norte-americano, que teve a participação como observador negada pelo anfitrião do evento. O documento produzido na ocasião também foi alvo de diversas críticas, por condenar o terrorismo contra "alvos civis", excluindo do rol de atos terroristas as "ações violentas contra ocupação estrangeira", como o Hamas. Ver artigo "Declaração defende resistência contra ocupação estrangeira", no link http://acervo.estadao.com.br/pagina/\#!/20050512-40749-spo-7-pola7-not/busca/contra+terrorismo.
} 
Embaixador Samuel Pinheiro Guimarães chamou "insubstituíveis" 34 as controvérsias do Governo Lula com o Governo Bush, principalmente em relação aos subsídios agrícolas, às disputas comerciais, ao respeito à soberania inviolável, ao terrorismo e à reforma da $\mathrm{ONU}^{35}$. Em linhas gerais, Lula almejava o reposicionamento do Brasil no cenário internacional, para que ao País fosse dado o reconhecimento de posição de "potência", o que pressuporia que o País ocupasse assento permanente no Conselho de Segurança, pretensão fundamental, que contrariava não apenas os norte-americanos, mas também países vizinhos, como a Argentina.

"Contrary to Fernando Henrique, President Lula da Silva's administration (20022010) opted for a more interventive, autonomous, and global foreign policy. The foreign Minister declared in his first speech, "[Brazil] will not run away from an engaged and leading role whenever it becomes necessary to defend the national interests and the values that inspire us... I refer callers cannot be confined to see the region can be restricted to a single dimension" (TAVARES: 2014, p. 110)

No que se refere ao terrorismo, paralelamente com a solidariedade brasileira na condenação dos atentados terroristas e na cooperação com iniciativas que visavam ao combate da lavagem de dinheiro na tríplice fronteira, o Governo Lula foi duro crítico à Guerra do Terror, negando, persistentemente, a existência de atividades terroristas no Brasil e na América do Sul. Seu governo demonstrou preocupação com a ingerência norte-americana na região a pretexto de Guerra às Drogas, e gerou indisposição com a Colômbia pela negação em classificar as FARC e o ELN como terroristas. ${ }^{36}$

"During Lula's mandate, Brazil's leadership was often equated with the personal style of the president and the foreign policy gained often a voluntaristic and personalist tone." (TAVARES: 2014, p. 114)

O viés esquerdista de Lula, a ênfase no combate à miséria e no fazer justiça para

\footnotetext{
${ }^{34}$ Ver declaração de Guimarães, Secretário-geral do Itamaraty, em 12.01.2004, disponível emhttp://acervo.estadao.com.br/pagina/\#!/20040117-40268-spo-19-eco-b6-not/busca/contra+terrorismo
}

\footnotetext{
${ }^{36}$ Ver artigo de 25.03.2005, "Alencar evita responder se as FARC são grupo terrorista”, disponível em: http://acervo.estadao.com.br/pagina/\#!/20050324-40700-spo-8-pol-a8-not/busca/Brasil+contra Entrevista com o embaixador Celso Amorim "Notícias do Itamaraty", disponível em: http://acervo.estadao.com.br/pagina/\#!/20080316-41788-spo-230-ali-j4-not/busca/Brasil+internacional http://acervo.estadao.com.br/pagina/\#!/20080316-41788-spo-230-ali-j4-not/busca/Brasil+internacional
} 
os excluídos ajudam a explicar o bom relacionamento do presidente com o Governo Chávez, da Venezuela. Embora Lula tenha buscado postura neutra, de mediação, sustentada na boa vizinhança, o governo brasileiro se empenhou em incorporar a Venezuela ao MERCOSUL, apesar da resistência do Paraguai e da oposição no Congresso Nacional. Apesar disso, ao longo de seus mandatos, Lula conseguiu consolidar a legitimidade de seu governo e de sua figura, como Estadista carismático, respeitado internacionalmente ${ }^{37}$.

\subsubsection{Lula na ONU}

Ao contrário de seu sucessor, Fernando Henrique Cardoso, Lula realizou todos os discursos do Brasil na ONU, com exceção do discurso de 2005. De modo geral, as estratégias discursivas e a linha argumentativa adotadas por Lula se mantiveram constantes, com pontuais variações, ao longo do período analisado (2003-2006). Em linhas gerais, embora a agenda diplomática do Governo Lula estivesse ancorada na pessoa do próprio presidente, no discurso Lula optou por neutralizar a primeira pessoa, distanciando o sujeito da mensagem. A estratégia de neutralização da primeira pessoa e a predominância da modalização delocutiva, pela adoção da terceira pessoa do plural (ao atribuir o locutor seus argumentos à entidade inanimada "o Brasil"), indicam que, na fala, Lula afasta de si a responsabilidade do conteúdo da mensagem, pressupondo uma espécie de verdade universal do conteúdo aí presente. Isso indica que o foco da estratégia argumentativa de Lula recai no lógos, como se verá a seguir.

Nos discursos de Lula, não ocorre a macrossecuritização do terrorismo, embora a ameaça terrorista seja instrumentalizada frequentemente. A intertextualidade com a Doutrina Bush e com a Guerra ao Terror é constante nos discursos, mas é trazida somente com o intuito de contestar e renegociar os argumentos apresentados, de forma a atender os escopos internos e os externos. Lula pressupõe alguns frames do terrorismo (barbárie, imoral, morte de inocentes), incorporando-os a seu programa de combate à fome. Na articulação do terrorismo com a luta contra a fome, Lula justifica

\footnotetext{
${ }^{37}$ Ver "Formadores de opinião na América Latina admiram Lula e desconfiam de Bush", material publicada pelo jornal Estado de São Paulo em 28.03.03, disponível em:

http://acervo.estadao.com.br/pagina/\#!/20031028-40187-spo-22-eco-b8-not/busca/contra+terrorismo
} 
seus programas para seu público doméstico e tenta mobilizar a audiência internacional ao associar esse "imperativo moral" à reforma da ONU e à suspensão dos subsídios agrícolas. Ao identificar as fontes do terrorismo à miséria, à pobreza e à exclusão, Lula rejeita a associação deste com extremismos e com o tráfico de drogas ${ }^{38}$. No discurso de Lula, o terrorismo é resultado da fome, sendo possível que se afirme que o presidente macrossecuritiza não o terrorismo, transferindo o foco da discussão para o combate à pobreza ${ }^{39}$.

\subsubsection{Linha argumentativa adotada nos discursos de Lula no Plenário da AGNU (2003-2006)}

A seguir, apresenta-se a análise dos discursos de Lula na Sessão Ordinária da Assembleia Geral das Nações Unidas (AGNU), proferidos entre os anos de 2003 e $2006^{4041}$. Primeiramente, identificam-se nos discursos os exemplos de modalização e de estratégia argumentativa para articular o tema do terrorismo. Em seguida, apresentam-se as tabelas de ocorrências explícitas do termo terrorismo e variantes entre os anos de 1999 a 2006, de processo de securitização do terrorismo no ato de fala perlocutório (seguindo a teoria de Buzan e Waever). Finalmente, resume-se a lógica argumentativa que está por trás dos discursos do presidente Lula na AGNU no período analisado.

\section{a) Modalização delocutiva e predomínio do lógos na argumentação:}

Nos discursos de Lula selecionados para a amostra, predominam a modalização delocutiva e a argumentação de cunho lógico, parte da articulação dos temas de

\footnotetext{
${ }^{38}$ Ver: "Viegas não quer forças armadas contra o tráfico", matéria publicada n’O Estado de São Paulo, 09.03.03, disponível em: http://acervo.estadao.com.br/pagina/\#!/20030309-39954-spo-10-pol-a10not/busca/internacional+contra+Brasil

${ }^{39}$ Ver: "Lula vai pregar guerra implacável contra a fome e a pobreza", matéria publicada n'O Estado de São Paulo, 22.01.03, disponível em: http://acervo.estadao.com.br/pagina/\#!/20030122-39908-spo-11-pola11-not/busca/contra+terrorismo)

${ }^{40} \mathrm{O}$ discurso de 2005 foi proferido pelo Ministro das Relações Exteriores no período, o Embaixador Celso Amorim.

${ }^{41}$ Todos os discursos estão disponíveis em :CORREA (2007)
} 
segurança. Essa tendência aparece em todos os exemplos apresentados a seguir, em ordem cronológica e na sequência em que aparecem no discurso. Para facilitar a identificação, sublinharam-se os elementos que caracterizam a modalização delocutiva.

\section{- Discurso do Presidente Lula na 58a Sessão Ordinária da AGNU, 2003}

Ex. 1. "Dois anos depois, ainda estão vivas em nossa memória as imagens do bárbaro atentado de 11 de setembro. Existe, hoje, louvável disposição de adotar formas mais efetivas de combate ao terrorismo, às armas de destruição em massa, ao crime organizado. Constata-se, no entanto, preocupante tendência de desacreditar a nossa Organização e até mesmo de desinvestir a ONU de sua autoridade política."

Ex. 2. "O aperfeiçoamento do sistema multilateral é a contraparte necessária do convívio democrático no interior das Nações. (...) As tragédias do Iraque e do Oriente Médio só encontrarão solução num quadro multilateral, em que a ONU tenha um papel central. No Iraque, o clima de insegurança e as tensões crescentes tornam ainda mais complexo o processo de reconstrução nacional. A superação desse impasse somente poderá ser assegurada a partir da liderança da ONU. Não apenas no restabelecimento de condições aceitáveis de segurança, mas também na condução do processo político, com vistas à restauração plena da soberania iraquiana no mais breve prazo. Sobre esse ponto não deve haver qualquer ambiguidade. A ONU não foi concebida para remover os escombros dos conflitos que ela não pôde evitar por mais valioso que seja o seu trabalho humanitário."

Ex. 3. "A paz, a segurança, o desenvolvimento e a justiça social são indissociáveis."

Ex. 4. "O verdadeiro caminho da paz é o combate sem tréguas à fome e à miséria, numa formidável campanha de solidariedade capaz de unir o planeta ao invés de aprofundar as divisões e o ódio que conflagram os povos e semeiam o terror." 
Ex.5. "A verdadeira paz brotará da democracia, do respeito ao direito internacional, do desmantelamento dos arsenais mortíferos e, sobretudo, da erradicação definitiva da fome."

\section{- Discurso do Presidente Lula na 59ª Sessão Ordinária da AGNU, 2004}

Ex. 6. "Da crueldade não nasce o amor. Da fome e da pobreza jamais nascerá a paz. $\underline{0}$ ódio e a insensatez que se alastram pelo mundo nutrem-se dessa desesperança, da absoluta falta de horizontes para grande parte dos povos.

Apenas neste ano, mais de 1.700 pessoas já morreram vítimas de ataques terroristas ao redor do mundo; em Madri, Bagdá e Jacarta.

Tragédias que vêm somar-se a tantas outras, na Índia, no Oriente Médio, nos Estados Unidos, e, recentemente, ao sacrifício bárbaro das crianças de Beslan."

Ex. 7. "A Humanidade está perdendo a luta pela paz. Só os valores do Humanismo, praticados com lucidez e determinação, podem deter a barbárie. A situação exige, dos povos e dos seus líderes, um novo senso de responsabilidade individual e coletiva."

Ex. 8. "O caminho da paz duradoura passa, necessariamente, por uma nova ordem internacional, que garanta oportunidades reais de progresso econômico e social para todos os países. Exige, por isso mesmo, a reforma do modelo de desenvolvimento global e a existência de instituições internacionais efetivamente democráticas, baseadas no multilateralismo, no reconhecimento dos direitos e aspirações de todos os povos."

Ex. 9. "O necessário combate ao terrorismo não pode ser concebido apenas em 
termos militares."

Ex. 10. "Só o Conselho de Segurança pode conferir legitimidade às ações no campo da paz e da segurança internacionais. Mas sua composição deve adequar-se à realidade de hoje, e não perpetuar aquela do pós-Segunda Guerra ou da Guerra Fria. Qualquer reforma que se limite a uma nova roupagem para a atual estrutura, sem aumentar o número de membros permanentes é, com certeza, insuficiente. As dificuldades inerentes a todo processo de reforma não devem fazer com que percamos de vista a urgência das mudanças."

- Discurso do Embaixador Celso Amorim (Ministro das Relações Exteriores do Brasil) na 60ª Sessão Ordinária da AGNU, 2005

Ex. 11. "O estabelecimento de uma Comissão para a Construção da Paz preencherá uma lacuna institucional importante. Será o elo, hoje inexistente, entre segurança e desenvolvimento."

Ex. 12. "A segurança humana resulta, principalmente, de sociedades justas e equitativas, que promovem os direitos humanos, fortalecem a democracia e respeitam o estado de direito, ao mesmo tempo em que criam oportunidades de desenvolvimento econômico com justiça social. As Nações Unidas não foram criadas para disseminar a filosofia de que a ordem deve ser imposta pela força. Esse recurso extremo deve ser reservado a situações em que todos os demais esforços tenham sido esgotados e as soluções pacíficas sejam realmente inviáveis. E o julgamento sobre a existência dessas condições excepcionais há que ser sempre um julgamento multilateral."

Ex. 13. "No último ano, testemunhamos novamente atos brutais de terrorismo. Civis, mulheres e crianças inocentes são hoje vítimas de grupos adversários dos valores que compartilhamos. Como país cuja identidade não pode ser dissociada das noções de 
tolerância e diversidade, o Brasil rejeita de maneira veemente esses atos abomináveis, que atentam contra a própria noção de humanidade (...) A luta contra o terrorismo não pode ser vista estritamente em termos de repressão por instituições policiais. Não podem tampouco tais ações resultar em mortes tão absurdas e indiscriminadas como as provocadas pelo próprio terrorismo."

Ex. 14. "Apesar de não haver vínculo automático entre pobreza e terrorismo, problemas socioeconômicos severos - em particular, quando combinados com a ausência de liberdades civis e políticas - são fatores que podem expor as comunidades a atitudes extremas de grupos fanatizados."

Ex. 15. "Apesar de não haver vínculo automático entre pobreza e terrorismo, problemas socioeconômicos severos - em particular, quando combinados com a ausência de liberdades civis e políticas - são fatores que podem expor as comunidades a atitudes extremas de grupos fanatizados. Expresso, desde já, a disposição brasileira de trabalhar intensamente com vistas à pronta conclusão de uma convenção abrangente sobre terrorismo."

\section{- Discurso do Presidente Lula na 61a Sessão Ordinária da AGNU, 2006}

Ex. 16. "Que não se iludam os países ricos, por mais fortes que hoje sejam, pois ninguém está seguro num mundo de injustiças. A guerra jamais trará segurança, a guerra só gera monstros, rancor, a intolerância, o fundamentalismo e a negação destrutiva das atuais hegemonias. É preciso dar aos pobres razões para viver, não para matar ou morrer."

Ex. 17. "Onde existe a fome não há esperança, há desolação e dor. A fome alimenta a violência e o fanatismo e um mundo de famintos nunca será um lugar seguro." 
Ex. 18. "Só haverá segurança no mundo se todos tiverem direito ao desenvolvimento econômico e social. O caminho da paz é o desenvolvimento compartilhado. Se não quisermos globalizar a guerra, é preciso globalizar a justiça, por isso, digo com a serena convicção de um homem que dedicou a sua vida a lutar pacificamente pelos direitos do povo trabalhador: a busca de uma nova ordem mundial, mais democrática e justa, não interessa apenas aos países pobres ou às nações emergentes, interessa tanto ou mais aos países ricos, se tiverem olhos para ver e ouvidos para ouvir, se não cometerem o desatino de ignorar o terrível clamor dos excluídos."

Ex. 19. "Conflitos como os do Oriente Médio vêm desafiando as autoridades das Nações Unidas. A recente crise no Líbano expôs a Organização a uma perigosa erosão de credibilidade. A eficácia das Nações Unidas tem sido seriamente questionada. $\mathrm{O}$ Conselho de Segurança é acusado de morosidade, incapacitado de agir com a rapidez requerida. A opinião pública mundial se mostra impaciente diante de dificuldades que custa a entender. A morte de civis inocentes, incluindo mulheres e crianças, choca a nossa sensibilidade."

Ex. 20. "O combate à fome e à pobreza, a paralisia da Rodada de Doha e o impasse no Oriente Médio são temas interligados. Seu bom caminho exige confiança nas soluções negociadas. Nesse momento, essa confiança está abalada, por isso, é extremamente grave. A ordem mundial que nos cabe construir deve basear-se no critério de justiça e respeito ao direito internacional. Só assim poderá haver paz, desenvolvimento e uma genuína convivência democrática na Comunidade de Nações."

b) Ocorrências explícitas do termo terrorismo e variantes nos discursos do Brasil na Sessão Plenária da ONU (1999-2006): 
Tabela 1. Ocorrências explícitas "terrorismo" nos discursos de Brasil (1999-2006)

\begin{tabular}{|l|r|r|r|r|r|r|r|r|r|}
\hline ocorréncia & 1999 & 2000 & 2001 & 2002 & 2003 & 2004 & 2005 & 2006 \\
\hline terrorismo & 1 & 0 & 8 & 1 & 1 & 2 & 6 & 1 \\
\hline terrorista & 0 & 0 & 4 & 0 & 0 & 0 & 0 & 0 \\
\hline terroristas & 0 & 0 & 1 & 3 & 0 & 1 & 0 & 0 \\
\hline terror & 0 & 0 & 1 & 1 & 1 & 0 & 0 & 0 \\
\hline total & $\mathbf{1}$ & $\mathbf{0}$ & $\mathbf{1 4}$ & $\mathbf{5}$ & $\mathbf{2}$ & $\mathbf{3}$ & $\mathbf{6}$ & $\mathbf{1}$ \\
\hline
\end{tabular}

\section{c) Securitização no ato de fala:}

Figura 2. Securitização no ato de fala: Brasil

Securitização do terrorismo nos discursos do Brasil (2003-2006)

\begin{tabular}{|c|c|c|c|}
\hline $\begin{array}{l}\text { Quem securitiza? } \\
\text { (ator) }\end{array}$ & $\begin{array}{c}\text { O que? } \\
\text { (objeto) }\end{array}$ & $\begin{array}{l}\text { Para quem? } \\
\text { (referente) }\end{array}$ & $\begin{array}{c}\text { Por que? } \\
\text { (justificativa) }\end{array}$ \\
\hline $\begin{array}{l}\text { - O Brasil (como Nação } \\
\text { fraternal) } \\
\text { - O governo Lula }\end{array}$ & - A fome/miséria/pobreza & $\begin{array}{l}\text { Para a felicidade, } \\
\text { dignidade e sobrevivência } \\
\text { de cada um dos indivíduos } \\
\text { do planeta }\end{array}$ & $\begin{array}{l}\text { - Porque leva ao terrorismo } \\
\text { - É uma arma de destruição } \\
\text { em massa. } \\
\text { - Atenta contra os valores } \\
\text { da humanidade }\end{array}$ \\
\hline
\end{tabular}

d) Encadeamento argumentativo (frames e intertextualidade): 
Figura 3. Encadeamento argumentativo: Brasil

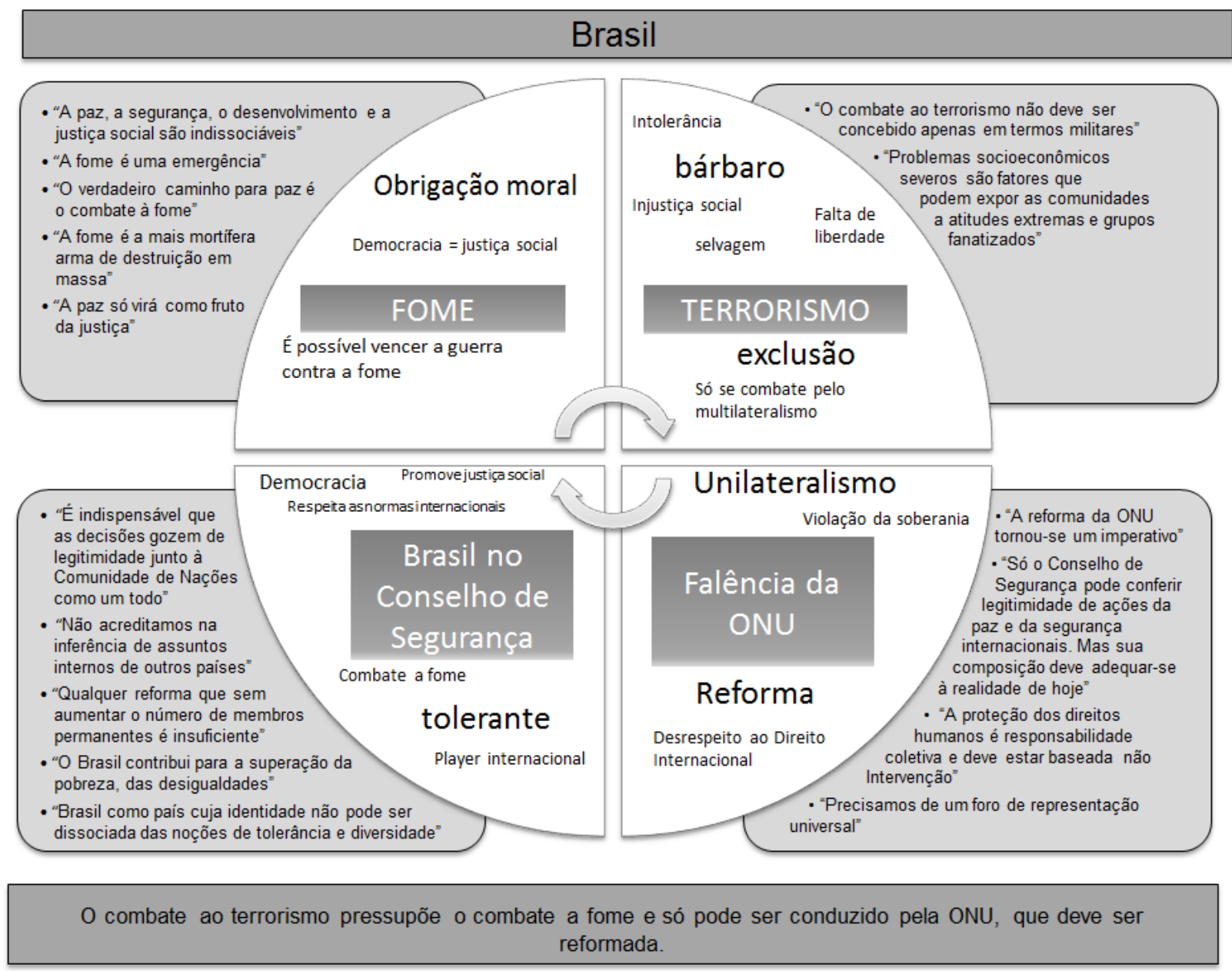

\title{
3.2. Colômbia
}

\author{
"Requerimos un compromiso total de la Comunidad Internacional en la lucha \\ contra el terrorismo en Colombia"
}

Uribe, em discurso na $59^{\mathrm{a}}$ Sessão Ordinária da AGNU, em Nova lorque.

$\mathrm{Na}$ história recente da Colômbia, dois fatos são fundamentais para entender a política interna e a inserção internacional do país: a luta contra os grupos insurgentes e a relação bilateral com os Estados Unidos. A repressão aos movimentos revolucionários de esquerda que se espalharam pela América Latina nos anos da 
Guerra Fria, em especial na Colômbia, explica, em grande medida, os estreitos laços que este país manteve com a Superpotência. A influência norte-americana no país foi traduzida pelo forte teor anticomunista adotado na condução política do país, seja a política externa (cujo alinhamento com os EUA foi acompanhado de isolamento do país em relação a seus vizinhos da América do Sul), seja a política interna, tendo sido o país um dos maiores beneficiários da assistência militar e econômica dos EUA na América Latina entre 1949 e 1974 (TICKNER, 2003 p. 170).

Na década de 1980, no entanto, após a ascensão de Belisario Beteas houve a tentativa de diversificar as parcerias colombianas internacionalmente, que, juntamente com Venezuela, México e Panamá, criaram o Grupo da Contadora, como forma de contrabalançar "Reagan's hardline policy in South America" (BAGLEY E TOKATLIÁN, 1985 p. 41) e diminuir a influência norte-americana na condução da política interna do país. A busca de maior independência relativamente aos EUA esteve presente no governo de Virgilio Barco (1986-1990) e no de Cesar Gaviria (1990-1994) e levou ao adensamento das relações diplomáticas do país com seus vizinhos da América do Sul e do Caribe, embora as relações econômicas da Colômbia permanecessem fortemente dependentes dos EUA.

Foi nos anos 1980, também, que os grupos insurgentes se lançaram ao tráfico de drogas como forma de financiamento de suas atividades. $O$ conflito armado entre grupos guerrilheiros, grupos paramilitares e as forças do governo, que se arrasta desde a década de 1960, ganhou novos contornos com a associação dos insurgentes ao narcotráfico, levando o país ao auge do conflito na década de 1990, com prolongamento pela década de 2000 (ORTIZ, 2008). Além das Forças Armadas Revolucionárias Colombianas (FARC), o Exército de Libertação Nacional (ELN) aparece, desde 1997, na lista de "grupos terroristas" elaborada pelo departamento de Estado dos Estados Unidos ${ }^{42}$, sendo que o grupo paramilitar de direita Autodefesa Unidas da Colômbia (UAC), também classificado, em 2001, como grupo terrorista pelo governo norte-americano, foi removido da lista em 2014.

A ênfase no combate ao narcotráfico adotada pelo Governo Clinton ${ }^{43}$ para a América Latina, por um lado, e, por outro, o escalonamento da guerra civil na Colômbia

\footnotetext{
${ }^{42}$ Disponível em: http://www.state.gov/j/ct/rls/other/des/123085.htm (último acesso: 3.5.2015).

${ }^{43}$ Apesar da relevância dada pelo Governo Clinton ao combate ao narcotráfico, a Guerra as Drogas começou a ser delineada pelo Governo Nixon (1971).
} 
e o apagamento do viés ideológico diante dos lucros advindos do comércio das drogas criaram o momentum para o restabelecimento da íntima relação entre Washington e Bogotá, dando origem ao Plano Colômbia. Esboçado entre os anos 1998 e 1999, entre o Governo Clinton e o presidente Andrés Prastana Arango, o Plano entrou em vigor no ano 2000. Descrito por Prastana como "Plano Marshall para a Colômbia", o Plano Colômbia contemplava o auxílio norte-americano nas esferas social, institucional e militar. De acordo com o sítio eletrônico da Embaixada norte-americana em Bogotá,

\begin{abstract}
“En respuesta al 'Plan Colombia' y consultándolo con el gobierno colombiano la administración de Estados Unidos ha propuesto una partida de US\$1.600 millones para ayudar a Colombia. Si se suma la asistencia a Colombia aprobada con anterioridad, de más de US\$330 millones, la nueva iniciativa requerirá US $\$ 954$ millones suplementarios para el año fiscal 2000 y otros US $\$ 318$ millones para el año fiscal 2001. El paquete propuesto por Estados Unidos ayudará a Colombia a abordar los enormes desafíos que enfrenta: combatir el tráfico ilegal de drogas, mejorar el cumplimiento de la ley, proteger los derechos humanos, expandir el desarrollo económico, institucionalizar la reforma judicial y promover la paz." (US EMBASSY BOGOTÁ, 2002) ${ }^{44}$
\end{abstract}

O auxílio oferecido pelo Plano Colômbia e o contexto de solidariedade internacional contra $o$ ataque terrorista de 11 de setembro contribuíram em grande medida para a eleição de Álvaro Uribe, em 2002, que objetivava terminar o conflito interno e restabelecer as instituições, com "mano firme, corázon grande". Das diversas mudanças legais e institucionais realizadas pelo Governo Uribe, sobressaem a Política de Segurança Democrática (que, embora tenha sido bem-sucedida em reduzir as taxas de violência interna, recebeu fortes críticas, principalmente quanto às declaradas violações de direitos humanos que permitiu) e a mudança da lei eleitoral que permitiu a reeleição ${ }^{45}$. Ao longo do mandato, a alta popularidade do presidente entre os colombianos somou-se ao apoio do Governo Bush em função da Guerra ao Terror e a críticas, desconfianças e crises entre os vizinhos da América do Sul (as ações do exército colombiano contra a guerrilha envolveram captura de guerrilheiros em território equatoriano e venezuelano, o que criou crises entre os países). Mesmo com a resistência dos vizinhos, Uribe procura articular a luta armada na Colômbia, a que passou a chamar de "luta contra o terrorismo" (VILLA e VIANNA: 2010, p. 67) fonte de

\footnotetext{
${ }^{44}$ Disponível em: (http://spanish.bogota.usembassy.gov/pcolombia004.html).

${ }^{45}$ Sobre a reeleição de Uribe, ver: http://acervo.estadao.com.br/pagina/\#!/20080316-41788-spo-230-alii4-not/busca/Brasil+internacional
} 
desestabilização do continente todo. ${ }^{46}$

\title{
3.2.1. Uribe na ONU
}

\begin{abstract}
"In Colombia, we recognize the link between terrorist and extremist groups that challenge the security of the state and drug trafficking activities that help finance the operations of such groups. We are working to help Colombia defend its democratic institutions and defeat illegal armed groups of both the left and right by extending effective sovereignty over the entire national territory and provide basic security to the Colombian people." (THE NATIONAL SECURITY STRATEGY OF THE UNITED STATES, 2002)
\end{abstract}

Dos discursos analisados na amostra, é nos do presidente Uribe que ocorre a macrossecuritização da Guerra ao Terror de modo mais evidente, análogo ao teor da Doutrina Bush. Uribe macrossecuritiza o terrorismo, aceitando a hegemonia norteamericana, embora negocie os frames para reforçar a conexão do terrorismo com o narcotráfico. Apoiado pelo Plano Colômbia e pela solidariedade internacional na luta contra o terrorismo após o ataque de 11 de setembro, Uribe incorpora a guerrilha ao terrorismo, que em seus discursos aparecem como sinônimos - o que será demonstrado, mais adiante, na tabela de ocorrências explícitas do termo terrorismo e suas variações, na qual se vê a baixa incidência dos termos nos discursos anteriores a 11 de setembro de 2001. Para o presidente, terrorismo e narcotráfico são dois lados da mesma moeda, e seu combate deve mobilizar todos os países do sistema internacional.

A temática da segurança internacional prevalece nos discursos de Uribe durante todo o período analisado e remete-se às noções de segurança tradicional, de cunho militar. Reiteradamente, o presidente tenta conciliar as "novas ameaças", como terrorismo transnacional, violência doméstica e estados falidos, com a discussão de segurança internacional clássica, para a qual o mais eficiente instrumento de defesa é a força. Uribe usa a ameaça da falência das instituições colombianas e a gravidade da ameaça "terrorista" para justificar a necessidade da adoção de medidas emergenciais para recuperar a soberania estatal, já que parcelas do território colombiano

\footnotetext{
${ }^{46}$ Ver matéria:

http://acervo.estadao.com.br/pagina/\#!/20021217-39872-spo-5-pol-a5-not/busca/terrorismo+Brasil.
} 
permaneciam sob o controle dos guerrilheiros.

O paralelismo de seu discurso com a Doutrina Bush é constante e bastante evidente. Assim como o presidente norte-americano, Uribe reconhece que a combinação de terrorismo com falência das instituições e com armas de destruição em massa legitima a adoção de medidas preventivas, inclusas as militares. Sua estratégia de fortalecimento do Estado está alinhada à Doutrina Bush, que visa à implementação da democracia pela via militar, a qual daria precedentes e justificativas às ações adotadas pelo governo colombiano, que incluíram o afrouxamento dos requisitos legais para a condenação de suspeitos e o emprego do exército para conter a violência interna, descritos em sua "Lei de Segurança Democrática".

A condição "universal" da ameaça narcoterrorista é evocada por Uribe para mobilizar o apoio da comunidade internacional na luta contra o narcotráfico e para legitimar sua política interna. Assim, se por um lado Uribe situa o problema das drogas para além do território da Colômbia (que, embora seja um dos principais países produtores de narcóticos, não se encontra entre os maiores consumidores, entre os quais estão, principalmente, os EUA e a Europa), reiterando a responsabilidade dos consumidores na cadeia do narcotráfico, por outro reforça a condição de seu governo como o único detentor do monopólio legítimo do uso da força dentro de suas fronteiras e, também, responde às críticas da comunidade internacional em face das ações adotadas por seu governo no âmbito doméstico.

A estratégia política é claramente expressa na estratégia discursiva adotada nas intervenções de Uribe na ONU. Em seus discursos, predominam a primeira pessoa do plural, prevalecendo o "nós inclusivo", e a modalização do tipo alocutiva, pela qual o sujeito falante transfere a responsabilidade de sua mensagem para o alocutário (neste caso, a comunidade internacional e o povo colombiano). Esses elementos permitem que se afirme que no discurso do presidente colombiano predomina o páthos, para 0 qual as emoções do alocutário são ativadas, com vistas à persuasão.

\subsubsection{Análise dos discursos}

A seguir, apresenta-se a análise dos discursos de Uribe na Sessão Plenária da 
Assembleia Geral das Nações Unidas (AGNU), proferidos entre 2002 e $2006^{47}$. Primeiramente, identificam-se nos discursos os exemplos de modalização e de estratégia argumentativa para articular o tema do terrorismo. Em seguida, apresentamse as tabelas de ocorrências explícitas do termo terrorismo e variantes no período compreendido entre os anos de 1999 a 2006, e do processo de securitização do terrorismo no ato de fala perlocutório (seguindo a teoria de Buzan e Waever). Finalmente, resume-se a lógica argumentativa que está por trás dos discursos do presidente Uribe proferidos na AGNU no período analisado.

\section{a) Modalização alocutiva e predomínio do páthos na argumentação:}

\section{- Discurso do Presidente Álvaro Uribe na 57ª Sessão Ordinária da AGNU, 2002}

Ex.1. "Los ataques terroristas del 11 de septiembre conmovieron al mundo y provocaron la justa condena universal. La humanidad debe estremecerse ante atentados como el cometido por guerrilleros el 2 de mayo en Bojayá, un poblado de mil habitantes. Allí fueron asesinadas 117 personas refugiadas en la iglesia."

Ex. 2. "Las viudas y huérfanos de la violencia en nuestro país se preguntan ¿por qué se asigna tanta importancia al terrorismo en otras áreas del mundo y tan poca por parte de algunos al terrorismo que agobia a Colombia? Esta petición la elevo desde el alma de nuestros profundos compromisos democráticos. Es difícil encontrar un país que enfrente semejante desafío terrorista y simultáneamente amplíe sus oportunidades democráticas."

Ex. 3. "El problema colombiano es un riesgo para la estabilidad democrática de la región. Necesitamos la ayuda del mundo para resolverlo. Pido la ayuda del mundo porque mi Gobierno tiene la decisión de derrotar el terror, de que no pasen estos 4

\footnotetext{
47 Todos os discursos estão disponíveis no site da Missão Colombiana ante às Nações Unidas, http://www.colombiaun.org/Asamblea\%20General/Comisiones/Plenario 60-55.html
} 
años como un nuevo triunfo de la delincuencia ni como una nueva prueba de la vacilación del Estado y la sociedad frente a la arrogancia de los violentos. Eliminar las fuentes de financiación del terror es imperativo. Por eso tenemos que vencer la droga y el secuestro."

Ex. 4. "El foro de las Naciones Unidas está preocupado por las armas de destrucción masiva, y nosotros compartimos esa angustia. Por favor, debemos entender que la droga tiene una capacidad de destrucción masiva, como la más temible de las armas químicas."

Ex. 5. "Tenemos la determinación de eliminarla. Pedimos al mundo un compromiso igual. No podemos continuar con decisiones y acciones a medias, tímidas. Mientras se divaga, el terrorismo siembra y trafica con más droga.

¡No nos envíen sus armas! ¡Eliminen sus mercados de droga y sus precursores químicos! ¡Ayúdennos con la interdicción aérea y el decomiso de la droga que navega por el Caribe y el Pacífico! “

- Discurso do Presidente Álvaro Uribe na 58ª Sessão Ordinária da AGNU, 2003

Ex. 6. "En la situación colombiana, terrorismo, droga, violencia e inseguridad son una misma cosa. Imploramos del mundo su compromiso para que derrotemos totalmente la droga. Imploramos del mundo que no alberguen a nuestros terroristas, nos ayuden a confiscarles sus bienes y solamente les abran sus puertas para ayudar a procesos de paz."

Ex. 7. "En la actualidad tramitamos una modificación Constitucional para permitir a la fuerza pública proceder con personal especializado, en casos de terrorismo, a 
efectuar capturas, allanamientos e interceptaciones. Con salvaguardias democráticas para que el fiscal independiente intervenga en el curso de las siguientes horas, la Procuraduría sea informada y también el Congreso, competente para el control político. Las atribuciones propuestas son infinitamente menores a normas vigentes en democracias sin nuestro riesgo terrorista."

Ex. 8. "Comprendo la preocupación que surge de atenuar la justicia frente a delitos graves, pero también debe entenderse que en un contexto de 30.000 terroristas, la paz definitiva es la mejor justicia para una Nación en la cual varias generaciones no han conocido un día sin actos de terror."

Ex. 9. "Nuestro problema es una amenaza internacional. Si Colombia no destruye la droga, la droga destruirá la cuenca amazónica. Si Colombia no frena el terrorismo, este pondrá en dificultades a las democracias de la región. De este modo lo han entendido el Presidente de Ecuador, Lucio Gutiérrez, y el Grupo de Río, que aprobó su proposición para que Naciones Unidas adelante esfuerzos tendientes a la negociación con los terroristas colombianos, o en su defecto se busquen alternativas para superar el problema."

Ex. 10. "Sería una tragedia que el mundo civilizado no uniera sus fuerzas para derrotar el terrorismo y para respaldar a las democracias que luchan contra él. Necesitamos la unión de todos los demócratas para derrotar el terror."

\section{- Discurso do Presidente Álvaro Uribe na 59a Sessão Ordinária da AGNU, 2004}

Ex.11. "Esa política muestra avances notables en reducción de homicidios, secuestros, otros actos terroristas, desplazamiento, siembras de drogas ilícitas. Aún es mucho lo que falta, pero con persistencia lo lograremos." 
Ex. 12. "Si descuidamos la seguridad democrática se crece el terrorismo, se pierde la ilusión de que podamos derrotarlo, se afecta la inversión, se disminuye el vigor de recuperación económica y nos quedaríamos sin recursos para la inversión social."

Ex. 13. "Estamos subsidiando más de 7.000 reinsertados de los diferentes grupos violentos. Esta acción es un gran proceso de paz, sin alardes pero efectivo. Cuando un reinsertado percibe la acogida y el apoyo del Estado y la comunidad, se reconcilia con las instituciones, abraza la democracia y la convivencia, y rechaza cualquier justificación de la violencia. Aspiramos que sean muchos miles más y requerimos el apoyo internacional a este programa."

Ex. 14. "Requerimos un compromiso total de la Comunidad Internacional en la lucha contra el terrorismo en Colombia. El terrorismo que sufre un país nutre y reproduce las redes del terror en el mundo entero. Las viudas y huérfanos de la violencia en nuestro país se preguntan ¿por qué se asigna tanta importancia al terrorismo en otras áreas del mundo y tan poca por parte de algunos al terrorismo que agobia a Colombia?"

Ex. 15. "Un Estado democrático tiene el derecho de pedir al mundo que, en lugar de reclamar un acuerdo claudicante con el terrorismo, se exija a los terroristas devolver a los secuestrados. Solicitamos al mundo más apoyo, más definido y más eficaz apoyo. Si éste se da, los grupos violentos no tendrán más camino que abandonar el terrorismo y aceptar la paz.

Unidos el pueblo colombiano, sus instituciones democráticas y la comunidad internacional, lograremos que Colombia sea un ejemplo de capacidad de derrotar el terrorismo y de cumplimiento de los derechos humanos, lograremos que Colombia sea un ejemplo de la capacidad de derrotar el terrorismo y de voluntad de construir justicia social."

- Discurso do Presidente Álvaro Uribe na 60ª Sessão Ordinária da AGNU, 2005 
Ex. 16. "Durante tres años consecutivos han disminuido el homicidio, el secuestro y otros crímenes terroristas. Todavía no hemos ganado la batalla contra el terrorismo, pero la estamos ganando. Esa victoria dará tranquilidad y progreso a Colombia y, erradicadas de su suelo las drogas ilícitas, el mundo sentirá inmenso alivio. Para ello necesitamos el concurso y el apoyo de la comunidad internacional."

Ex. 17 "El concepto de seguridad que profesamos y practicamos, al fortalecer la confianza ciudadana en las instituciones, exige que los violentos cesen hostilidades y se apresten a negociar el respeto definitivo a la paz. La acción decidida y firme de combatir a quienes ejercen el terror, de la mano de una política generosa para quienes deciden dejar la intimidación por las armas, ha permitido la desmovilización y reinserción de 20.000 terroristas, de cerca de 50.000 que encontramos. El Gobierno mantiene abiertas las puertas de la negociación, bajo la condición de que se acepte el cese de hostilidades.

Necesitamos el apoyo del mundo a nuestros planes de reinserción. Imaginen ustedes el tamaño del desafío: 20.000 reinsertados que podrán duplicarse en los años venideros. Personas que han vivido de las armas, acostumbradas a matar. ¿Qué mejor contribución a la paz que el abandono definitivo de la ilegalidad? Por ello requerimos el apoyo del mundo para brindar a los reinsertados oportunidades de rehabilitación e integración social."

Ex. 18. "Para erradicar la droga que financia el terrorismo, hemos aumentado las fumigaciones y estamos muy optimistas con la erradicación manual, que al terminar 2005 debe completar 30.000 hectáreas destruidas. Requerimos más apoyo del mundo para encontrar oportunidades alternativas a nuestros campesinos

Ex.19. "Somos firmes en la lucha contra el terrorismo y firmes en la convicción de que una victoria permanente y sostenida depende del éxito en la lucha de cada país por la cohesión social. Al proyectar nuestra política de seguridad para que se convierta en un 
axioma de Estado, la concebimos inexorablemente acompañada del permanente mejoramiento de la situación social de nuestro pueblo."

Ex. 20 "Nuestra política social también comprende un esfuerzo constante para fortalecer los programas de desarrollo alternativo, que permitan superar de manera definitiva el problema de las drogas ilícitas. En éstos, la comunidad internacional tiene una oportunidad única para contribuir $y$ hacer efectivo el principio de corresponsabilidad."

- Discurso do Presidente Álvaro Uribe na 61ª Sessão Ordinária da AGNU, 2006

Ex. 21. "Vengo hoy a Naciones Unidas a pedir apoyo resuelto a nuestra política de seguridad y al programa de reinserción. La violencia colombiana ha tenido mucha publicidad internacional, crítica constante al Estado y poca ayuda para superarla. Es tiempo para que la comunidad internacional emplace, de manera perentoria, a los grupos violentos a hacer la paz sin más dilaciones. El Gobierno es tan firme para implementar la seguridad, como riguroso para respetar las reglas democráticas y abierto y generoso para buscar la paz. Una muestra sincera de voluntad de paz no tropezará con obstáculos gubernamentales para llegar a la reconciliación definitiva."

Ex. 22. "La comunidad internacional debe apoyar, de manera más decidida, nuestra política de seguridad. De este modo se acelerarán resultados de superación de violencia y búsqueda de paz."

Ex. 23. "Para nosotros la violencia organizada, con móviles políticos ficticios, es terrorismo y la seguridad es camino de paz. Cuando hay una democracia de por medio, pluralista, vigorosa, garantista, la acción armada contra ella es puro terrorismo. Negarlo haría que no hubiese diferencia entre el combate armado a las dictaduras, que 
ameritó en otros países el reconocimiento a grupos insurgentes y la agresión violenta padecida por nuestra democracia, agresión que es terrorismo."

Ex. 24. Colombia ha elegido, bajo la seguridad democrática, alcaldes, gobernadores y congresistas de todas las tendencias. La seguridad ha contenido al terrorismo para que se exprese la democracia. Aún nos falta mucho en seguridad y todavía no se vislumbra la paz definitiva, pero los avances son innegables. La protección efectiva de los colombianos se traduce en la caída del número de homicidios, secuestros, actos terroristas, crímenes y amenazas contra periodistas y líderes de organizaciones de trabajadores."

Ex. 25. "Los colombianos no queremos quedarnos en esfuerzos y sacrificios, requerimos resultados. Estamos dispuestos a revisar nuestra estrategia, a mejorarla, pero necesitamos que el mundo entero se involucre con nosotros. Pido a Naciones Unidas esfuerzos adicionales que nos ayuden a encontrar senderos de eficacia.."

\section{b) Ocorrências explícitas do termo terrorismo e variantes nos discursos da Colômbia na Sessão Plenária da ONU (1999-2006):}

Tabela 2. Ocorrências explícitas "terrorismo" nos discursos de Colômbia (1999-2006)

\begin{tabular}{|l|r|r|r|r|r|r|r|r|r|}
\hline ocorréncia & 1999 & 2000 & 2001 & 2002 & 2003 & 2004 & 2005 & 2006 \\
\hline terrorismo & 1 & 0 & 9 & 1 & 10 & 10 & 4 & 4 \\
\hline terrorista & 0 & 0 & 0 & 1 & 2 & 2 & 1 & 0 \\
\hline terroristas & 0 & 0 & 3 & 3 & 9 & 2 & 3 & 3 \\
\hline terror & 1 & 0 & 0 & 3 & 3 & 3 & 2 & 0 \\
\hline total & 2 & 0 & 11 & 8 & 24 & 20 & 10 & 7 \\
\hline
\end{tabular}




\section{c) Securitização do terrorismo no ato de fala:}

Figura 4. Securitização no ato de fala: Colômbia

Securitização do terrorismo nos discursos da Colômbia (2002-2006)

\begin{tabular}{|c|c|c|c|}
\hline $\begin{array}{l}\text { Quem securitiza? } \\
\text { (ator) }\end{array}$ & $\begin{array}{c}\text { O que? } \\
\text { (objeto) }\end{array}$ & $\begin{array}{l}\text { Para quem? } \\
\text { (referente) }\end{array}$ & $\begin{array}{c}\text { Por que? } \\
\text { (justificativa) }\end{array}$ \\
\hline $\begin{array}{l}\text { - Opresidente da Colômbia } \\
\text { (Álvaro Uribe) } \\
\text { - O Estado Colombiano (= a } \\
\text { Colômbia que se define } \\
\text { por suas instituições } \\
\text { democráticas e império da } \\
\text { lei). }\end{array}$ & $\begin{array}{l}\text { - O terrorismo (é um só, } \\
\text { apesar de abarcar } \\
\text { "qualquer açãa violenta } \\
\text { ilegitima", que pode se } \\
\text { manifestar sob diferentes } \\
\text { formas e pretextos). }\end{array}$ & $\begin{array}{l}\text { - Para o Estado colombiano } \\
\text { - Para as instituiç̋̋es } \\
\text { democráticas } \\
\text { - Países vizinhos e } \\
\text { comunidade internacional } \\
\text { (Estados) no geral } \\
\text { - Para os inocentes }\end{array}$ & $\begin{array}{l}\text { - Para as segurança e } \\
\text { sobrevivência do: } \\
\text { - Estado Colombiano } \\
\text { - Instituições democráticas } \\
\text { - Dos inocentes } \\
\text { - Manter estabilidade } \\
\text { Regional e Segurança } \\
\text { Internacional } \\
\text { - Para combater a miséria/ } \\
\text { fome/pobreza }\end{array}$ \\
\hline
\end{tabular}

\section{d) Encadeamento argumentativo (frames e intertextualidade):}

Figura 5. Encadeamento argumentativo: Colômbia

\section{Colômbia}

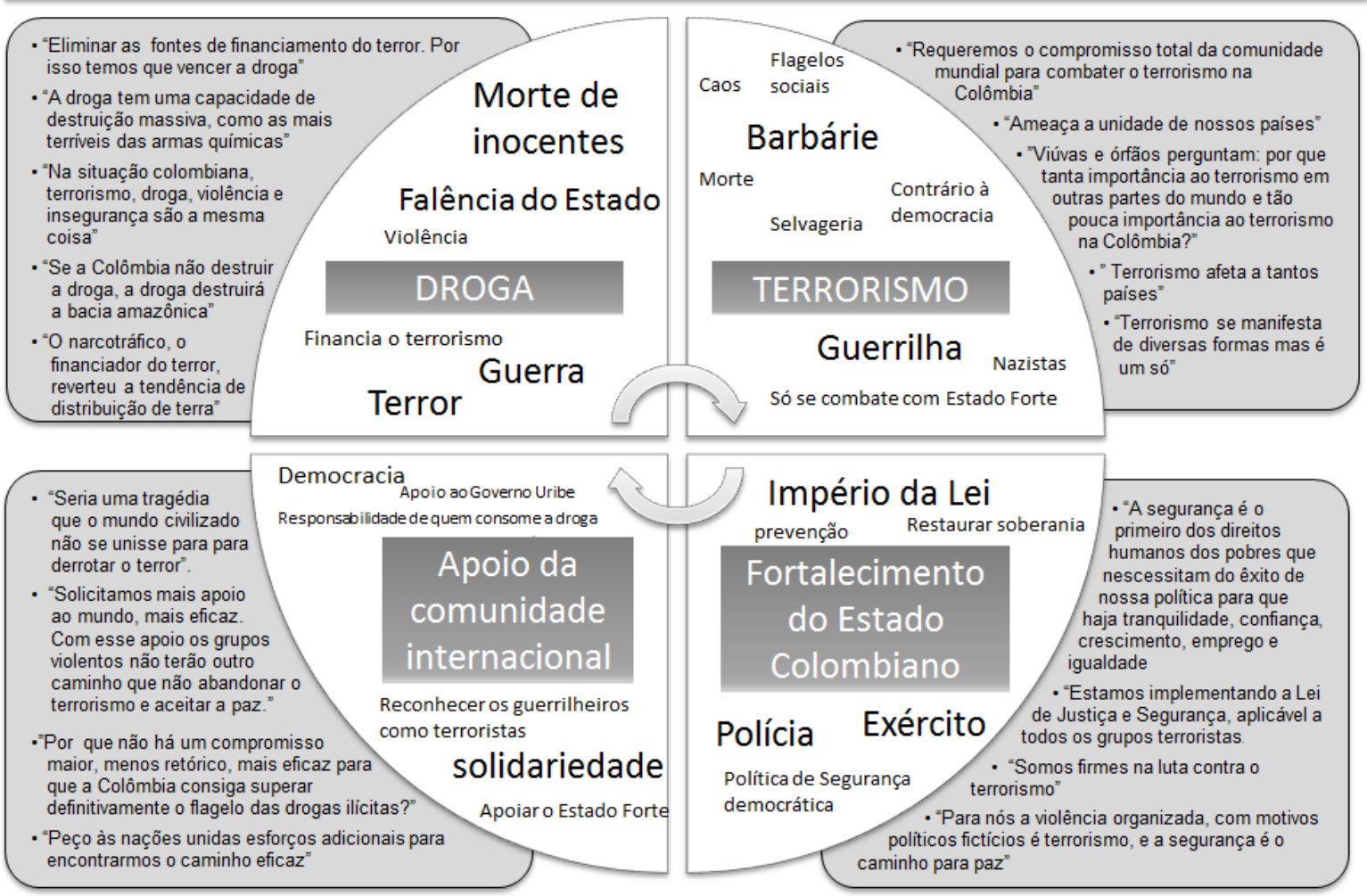

O Narcotráfico financia o terror e é o terrorista. Combatê-lo exige Estado Forte, poder duro e reconhecimento da legitimidade do Governo Uribe. 


\subsection{Venezuela}

"Sólo los pueblos conscientes logran derrocar, barrer, con estos intentos fascistas y terroristas."

Chávez, em discurso na 57ª Sessão Ordinária da AGNU, em Nova lorque.

A Venezuela é considerada o país sul-americano de mais longa tradição democrática (NAíM, 2001), já que, na segunda metade do século XX, enquanto a maior parte dos países da região estava sob domínio militar, o país suplantou uma década de ditadura de Marco Peres Jiménez (1952-1958) por meio de pacto de conciliação denominado Pacto Punto Fijo, em 1958. Expresso na Constituição de 1961, o pacto estabeleceu a base para o sistema de democracia clientelista (em que os partidos de esquerda foram excluídos), financiada pela venda de petróleo; o sistema vigorou até os anos 1980 (VILLA, 2005), passou por reformas nos anos 1990, até ser suplantado pelo "Socialismo do século XXI", de Hugo Chávez, que deu início à "Revolução Bolivariana".

As condições para a eleição de Chávez começaram a se delinear uma década antes e datam da conjuntura que motivou s protestos populares conhecidos por "EI Caracazo", de 1989. Em oposição às reformas de cunho neoliberal levadas a cabo pelo governo de Carlos Andrés Pérez (promoveu a política do gran viraje), os protestos do Caracazo mobilizaram mais de 1 milhão de pessoas ao redor do país e foram brutalmente repreendidos pelas forças do governo. Até hoje, não se sabe ao certo quantas pessoas morreram na ocasião.

"O comportamento negativo da economia nos anos de 1980 afetou de forma relevante a base material redistributiva do regime venezuelano, fato que mostrava que a eficácia política do Pacto de[?] Punto Fijo estava intrinsecamente atrelada ao comportamento do modelo rentista petrolífero. Com a crise dos anos de 1980, a chamada década perdida, toda a América Latina enfrentou uma derrocada econômica, que acabou por condicionar profundamente as opções neoliberais econômicas feitas pelas elites políticas na região latino-americana. No caso da Venezuela, a situação agravou-se devido à queda dos preços internacionais do petróleo, a partir do ano de 1984, e também ao aumento nos encargos da dívida externa. O regime democrático, que entre 1965 e 1980 havia sido capaz de manter um ritmo de aumentos salariais relativamente constantes e do gasto social, claras resultantes do aumento dos preços do petróleo, via reduzida esta capacidade. O PIB per capita, que havia chegado a um teto máximo em finais dos anos de 1970, caiu cerca de $20 \%$ nos anos de 1980 , fazendo com que os indicadores regredissem 
àqueles dos anos de 1960 (ROBERTS: 2003, p. 80; CRISP: 2000, p. 175)." (VILLA: 2005)

Nos primeiros anos década de 1990, a crise econômica iniciada na década anterior, atribuída à queda dos preços do petróleo, ao escalonamento da dívida externa e à escassez de crédito, aprofundou ainda mais a crise social do país, com aumento da pobreza e da concentração da renda. A piora dos índices socioeconômicos foi acompanhada por crise política, que culminou em tentativa de golpe militar, em 1992, empreendida por setor das forças armadas que se intitulava Movimento Bolivariano Revolucionário, MBR 200. A tentativa de golpe possibilitou que o governo instaurasse estado de emergência no país, em função do qual se suspenderam os direitos constitucionais e impuseram-se restrições à imprensa.

Embora o governo Pérez tenha suprimido o golpe e levado Chávez à prisão, a crise revelou a exaustão do modelo instaurado pelo Pacto Ponto Fijo e comprometeu a reputação de estabilidade democrática que o país gozava internacionalmente (SERBIN, 1996 p. 90). O impeachment do presidente Pérez, em 1993, motivado por corrupção e desvio de verbas, acentuou a crise generalizada no país e contribuiu para a perda de credibilidade das instituições democráticas e das elites dominantes (VILLA, 2009). Os três presidentes que sucederam a Pérez (Octavio Lepage, que governou de maio a junho de 1993; Ramón J. Velázquez, de junho de 1993 a fevereiro de 1994; Rafael Caldera Rodríguez, que foi eleito em 1994 e terminou o mandato em 1998) não conseguiram conter a crescente insatisfação da população, que, desencantada com os partidos existentes, abraçou o projeto populista de Chávez (a quem o presidente Caldera havia concedido perdão), elegendo-o presidente em 1998, com $58 \%$ dos votos válidos (VILLA, 2005).

\footnotetext{
"Desde mediados de los años 90 todos los Estados del mundo andino han vivido en permanente crisis política definida por una legitimidad precaria, producto de un déficit crónico de representación. Este déficit tendría por lo menos tres características: a) la mayor parte de la gente no participa en los procesos de toma de decisión estratégicos nacionales, y tampoco en aquellos que se refieren a los asuntos particulares de sus comunidades; b) no existen mecanismos eficientes ni legítimos de rendición de cuentas (los niveles de impunidad, tanto en la sociedad civil, cuanto en el ejercicio del poder político, s son extremadamente altos); y c) una parte importante de las sociedades carece de la calidad de ciudadanía." (BONILLA: 2001, p.52)
} 
Chávez chega disposto a extirpar os males da democracia neoliberal, que serviria aos interesses norte-americanos, em função do petróleo, e assolava o país em crise. Na política interna, Chávez optou por modelo peculiar de democracia participativa dominada por militares, que pressupôs uma série de referenda e suspensão dos mecanismos de controle das instituições do Estado (freios e contrapesos). Em 1999, aprovou nova Constituição, que concentrou o poder nas mãos do presidente, que passou a ter competência para legislar sobre qualquer matéria pela lei habilitante (VILLA, 2005). A figura do presidente passou, então, a personificar a política da Venezuela, tanto no âmbito interno quanto no âmbito externo, para o qual o país adotou estratégia de inserção fortemente atrelada às caraterísticas e preferências pessoais do presidente: a liderança carismática, a valorização do mestiço e das raízes indígenas e dos excluídos, a fé cristã, a oposição ao neoliberalismo ${ }^{48}$.

\subsubsection{Chávez na ONU}

O tom assertivo do discurso doméstico de Chávez durante a campanha eleitoral em 1998, por meio do qual destinou duras críticas aos adversários (VILLA, 2005), cedeu lugar ao tom amigável que marcou os primeiros discursos na ONU, nos quais o presidente tentou assegurar à comunidade internacional a legitimidade de seu governo e o compromisso com a democracia. Na medida em que Chávez consolidou sua aprovação interna e as mudanças institucionais adotadas, os discursos do presidente na ONU recuperaram, progressivamente, o tom enfático do período pré-eleitoral. Dois eventos podem ser associados à radicalização: o golpe de Estado de 11 de fevereiro de 2002 e a recusa do Governo Bush em extraditar Luis Posada Carilles, em 2006. para julgamento na Venezuela. Esses dois eventos são simbólicos da crescente tensão

\footnotetext{
${ }^{48}$ Ver matéria " Chávez, em nome dos 'povos do Sul', Bush é um tirano, terrorista, o Diabo" disponível em: http://acervo.estadao.com.br/pagina/\#!/20060921-41246-spo-19-int-a20-

not/busca/terrorismo+internacional
} 
das relações bilaterais de Venezuela e EUA, cujo pico de hostilidades pode ser identificado nos discursos proferidos por Chávez na ONU no ano de 2006, nos quais se pode observar mudança na adjetivação para descrever as ações do Governo Bush.

A enfática oposição de Chávez ao Governo Bush, ao neoliberalismo, ao imperialismo e à hegemonia norte-americana causa surpresa quando contrastada com a conclusão a que se chega no final da análise da amostra: Chávez macrossecuritiza a Guerra ao Terror, instrumentalizando-a para condenar o Capitalismo neoliberal, o Governo Bush e a oposição interna, "golpista". Paradoxalmente, Chávez nega a hegemonia norte-americana sob o Governo Bush, sem negar a legitimidade da Guerra ao Terrorismo, do embate entre o bem e o mal, e o dever moral da comunidade internacional de eliminar os atos bárbaros, embora condene por completo as ações adotadas no âmbito da Guerra ao Terror, de Bush. Em consonância com os frames de que o terrorismo tenha como alvo os "inocentes", de que é prática "selvagem", "bárbara" e "anticristã", Chávez contesta a figura do terrorista e suas causas. Chávez identifica, em seus discursos, diversas modalidades de terrorismo (em que o caráter injusto e imoral é presente), que ele atribui, principalmente, ao neoliberalismo e ao imperialismo de Bush.

O caráter personalista da gestão de Chávez apresenta-se, também, nas estratégias discursivas adotadas. Em seus discursos na Sessão Plenária da AGNU, predomina a modalização do tipo elocutiva, cujo foco recai no sujeito falante, "eu". De todos os discursos da amostra, é nos de Chávez que a primeira pessoa do singular e, por vezes, a primeira do plural pelo "nós exclusivo" aparecem com maior frequência. Em seus discursos, altamente adjetivados e mais longos do que os dos demais presidentes que aqui se analisaram, Chávez assume postura centrada na sua própria figura, assumindo para si a responsabilidade da mensagem (com várias referências de tempo e de lugar da cena enunciativa). Destarte, predomina, nos discursos de Chávez, a estratégia argumentativa baseada no éthos (embora o páthos também seja evocado com certa frequência), por meio do qual a legitimidade da mensagem se estabelece a partir do sujeito falante, "eu".

\subsubsection{Análise dos discursos}


A seguir, apresenta-se a análise dos discursos de Chávez na Sessão Plenária da Assembleia Geral das Nações Unidas (AGNU), proferidos entre 2002 e $2006^{4950}$. Primeiramente, identificam-se nos discursos os exemplos de modalização e de estratégia argumentativa para articular o tema do terrorismo. Em seguida, apresentamse as tabelas de ocorrências explícitas do termo terrorismo e variantes no período de uma década (1999-2006) e de ocorrências do processo de securitização do terrorismo no ato de fala perlocutório (seguindo-se a teoria de Buzan e Waever). Finalmente, resume-se a lógica argumentativa que está por trás dos discursos do presidente no período.

a) Modalização elocutiva e predomínio do éthos na argumentação

\section{- Discurso do Presidente Hugo Chávez na 57ª Sessão Ordinária da AGNU, 2002}

Ex.1. "Escrito está, en el libro de los siglos, que recoge la palabra de Dios, que el único camino a la paz es la justicia. La condena firme al terrorismo, señor Presidente, señoras y señores, tiene que ir también acompañada de una infinita voluntad política de los líderes del mundo para reconocer, por ejemplo, que el sistema económico internacional imperante hoy, - como un combustible para los incendios - basado en la doctrina perversa del neoliberalismo salvaje, genera cada día más miseria, genera cada día más desigualdad y genera cada día más desesperanza en los pueblos pobres del planeta."

Ex.2 "Pero así como condenamos, señor presidente, el terrorismo mundial y sus causas, también he venido a esta Asamblea General, a nombre del heroico pueblo de Simón Bolívar, a denunciar en voz alta otros tipos de terrorismo y otros tipos de

\footnotetext{
${ }^{49}$ O discurso de 2003 foi proferido pelo então Ministro das Relações Exteriores no período, o Embaixador Roy Chaderton Matos. Em 2004, quem se dirigiu à ONU foi o chanceler da Venezuela, o Embaixador Jesús Arnaldo Pérez.

${ }^{50}$ Todos os discursos estão disponíveis em: CHÁVEZ FRÍAS (2009)
} 
causas. En Venezuela, señor presidente, fue desatado un proceso de terrorismo sistemático, planificado, que hizo irrupción violenta, abierta y sangrienta un día 11 también, pero no de septiembre, sino de abril de este año 2002, hace cinco meses, día aquél en el que un golpe de Estado fascista derrocó al Gobierno legítimo que me honro en presidir, para luego instalar una brevísima dictadura que llenó de terror las calles, las ciudades y los pueblos de nuestra querida Venezuela."

Ex. 3 "Unas élites golpistas que utilizaron el terrorismo económico, y pretenden seguirlo utilizando; una élites privilegiadas que utilizaron el terrorismo policial y el terrorismo militar y lograron una alianza muy poderosa, que logró derrocar el Gobierno, que logró hacerme prisionero e incomunicarme durante casi 48 horas en una isla del Caribe. Un golpe fascista que eliminó la Asamblea Nacional, que eliminó en un decreto los poderes públicos —eliminó el Poder Judicial—; que detuvo y envió a prisión a diputados, gobernadores y alcaldes elegidos por el pueblo.

(...) “ioh, milagro de Dios!—, en menos de 48 horas, aquel heroico pueblo de Simón Bolívar, junto a sus soldados patriotas barrieron la tiranía, restituyeron la Constitución, rescataron al Presidente prisionero y secuestrado y reinstalaron el proyecto democrático venezolano.

¡Milagro de los pueblos! Sólo los pueblos logran eso, sólo los pueblos unidos, sólo los pueblos conscientes logran derrocar, barrer, con estos intentos fascistas y terroristas."

Ex.4. "Luego de esos acontecimientos, señor presidente, para ir concluyendo - ya veo que la luz roja se ha prendido-, los venezolanos sabemos, los venezolanos conocemos - lo que pasa es que hay mucha gente que no ha llegado- conocemos y hemos sentido en carne propia lo que es el terrorismo. Vea, señor presidente, hace pocos días apareció un video, una prueba más de lo que en Venezuela se planificó, donde un periodista internacional hace unas revelaciones, y ese periodista internacional dice que a él lo llamaron el día del golpe, en la mañana, y que mucho antes de que cayera el primer muerto, producto de los disparos de un grupo de francotiradores, algunos incluso extranjeros, que masacraron parte de nuestro pueblo, antes de que cayera el primer muerto, ya los golpistas estaban grabando un mensaje, 
donde decían que el presidente Chávez había mandado a matar al pueblo, y que ya iban seis muertos, mucho antes de que se iniciaran los disparos y la masacre a un pueblo indefenso, a una sociedad indefensa.

Ex. 5. "Ahora, agradecemos la inequívoca condena de la comunidad internacional a aquel golpe de Estado, a aquel horror que vivimos unos días en Venezuela, y ratificamos que nuestro Gobierno, al que los venezolanos han ratificado su confianza en sucesivos procesos electorales, no volvió cortando cabezas ni estableciendo cacerías de brujas, ni haciendo juicios sumarios; volvió - como canta el pueblo por las calles: "¡Volvió, volvió, volvió, volvió"; es una canción que anda por las calles de Venezuela - apegado estrictamente a nuestra vocación y acción bolivariana humanista y libertaria, apegado estrictamente a nuestra Constitución Nacional, con la Constitución en la mano; volvió de la marea popular, que lo restableció en su sitio junto a la Constitución y le dio una soberana lección democrática al terrorismo, a los terroristas, al golpismo y a los golpistas"

\section{- Discurso do Embaixador Roy Chaderton Matos (Ministro das Relações Exteriores de Venezuela) na 58ª Sessão Ordinária da AGNU, 2005}

Ex. 6. "Señor Presidente, hace un año, en esta misma sala, condenábamos los abominables ataques terroristas del 11 de septiembre, donde perdimos a miles de ciudadanos estadounidenses $\mathrm{y}$ de otros países. Ese holocausto súbito fue quizá producto del fundamentalismo religioso, pero es injusto singularizar a los creyentes de una fe por actos de minorías extremistas, cuando otras minorías de creyentes también han cometido crímenes contra la humanidad, en el nombre del Señor. El terrorismo destruye la vida humana de inocentes y combatientes. Es impronta que atormenta a familiares, a amigos y pueblos. No hay terrorismo bueno. Ni en el nombre de una etnia o la nacionalidad. Ni en el nombre de la justicia o la libertad. Ni en el nombre de Dios.

Ex. 8. "Es así, señor presidente, como todos los miembros de nuestra organización, 
debemos centrar nuestros esfuerzos para encontrar los medios necesarios que nos permitan asegurar la paz y la democracia, en casa y en la comunidad internacional, valiéndonos del mejor antídoto contra la violencia: la justicia social."

Ex. 9. "Parece que nada ha cambiado. La injusticia social se eterniza, los conflictos se repiten, protagonistas de los cambios históricos son eliminados físicamente 0 destruidos moralmente, y la prédica violenta nos arrastra hacia el terrorismo y la guerra."

Ex. 9. "Los mismos valores nos inspiran en Venezuela, un país que se ufanaba de ser el más rico y el más democrático de la América Latina, pero desaprovechó sus privilegiadas oportunidades históricas y cayó en un proceso de descomposición ética y social que nos acercó al abismo. Así, tuvimos que emprender un profundo proceso de cambio en paz y en democracia. Los sectores afectados por el cambio democrático han recurrido a la fuerza para frustrar este empeño de mayorías; recurrieron al golpe militar, al sabotaje petrolero, al pánico financiero y al terrorismo mediático. A Dios gracias fracasaron, pero causaron mucho daño.

Ex. 10. "Sin embargo, debemos proseguir la lucha frontal contra los terrorismos más extendidos y destructores: la pobreza y la exclusión social. El mundo en desarrollo sufre del hambre, de la miseria y de la exclusión, causados por un sistema económico injusto, envuelto en las prácticas del neoliberalismo salvaje, en la economía globalizada, con un esquema de intercambio comercial desequilibrado, que genera desempleo, explotación, desigualdad y resentimientos. Es un sistema que atenta contra la dignidad de la persona humana. Sus líderes no acostumbran hablar de justicia social en sus declaraciones. Una iniciativa que ha emprendido el presidente Hugo Chávez Frías, para combatir la pobreza, es la creación de un Fondo Humanitario Internacional, que hemos propuesto en Monterrey, en Johannesburgo y, una vez más, en esta Asamblea General de la ONU." 


\section{- Discurso do Embaixador Jesús Arnaldo Pérez (Chanceler da Venezuela) na 59å Sessão Ordinária da AGNU, 2004}

Ex. 11. "Señor Presidente, distinguidos jefes de delegación, excelencias, señoras y señores. Hay momentos que podemos describir como cruciales para la historia, cuando las naciones y los pueblos deben decidir de qué lado están. Este es uno de esos momentos con base en los cuales la historia nos juzgará y examinará si fuimos lideres democráticos que representaron la voluntad de sus pueblos. Está claro que los pueblos del mundo han adoptado una posición de rechazo a la economía neoliberal y a la guerra."

Ex.12. Para nosotros, la cuestión preponderante consiste en saber si estamos construyendo un mundo en donde impere la democracia verdadera, la igual dad y la justicia o un mundo regido por la tiranía del poder económico y militar."

Ex.13. "Desde las postrimerías del pasado milenio presenciamos un disenso tremendo por parte de los pueblos frente a los efectos del neoliberalismo y la guerra."

Ex. 14. "Si sumamos las protestas contra la globalización neoliberal a las manifestaciones contra la guerra, hallaremos que se está produciendo una rebelión global de proporciones revolucionarias y tendremos que decidir si marchamos en las calles junto a nuestros pueblos o nos escondemos en las torres de marfil."

Ex. 15. "Pués bien, en Venezuela y bajo el impulso del presidente Hugo Chávez Frías, este postulado se está haciendo realidad, dándole poder a los pobres. Para disminuir la pobreza es necesario aumentar la democracia. No hay otra vía. La democracia es también la única vía para derrotar al terrorismo, si bien la miseria y el hambre crean las condiciones para su existencia, no hay terrorismos buenos y malos. Hay sólo un terrorismo condenable, detestable y cobarde, pero una vez más sólo con más 
democracia se le puede derrotar."

- Discurso do Presidente Hugo Chávez na 60ª Sessão Ordinária da AGNU, 2005

Ex. 16. "Hoy sabemos que nunca existieron armas de destrucción masiva en Iraq, el pueblo estadounidense siempre ha sido muy riguroso con la exigencia de la verdad a sus gobernantes, los pueblos del mundo también: nunca hubo armas de destrucción masiva y, sin embargo y por encima de Naciones Unidas, Iraq fue bombardeado, ocupado y continúa ocupado. Por eso proponemos a esta Asamblea que Naciones Unidas salga de un país que no es respetuoso con las propias resoluciones de esta Asamblea."

Ex. 17. "Óigame una cosa, señor presidente, si nosotros vamos a aceptar esto es porque estamos perdidos, iapaguemos la luz y cerremos las puertas y cerremos las ventanas! Sería lo último, que aceptemos la dictadura aquí en este salón. Ahora más que nunca -decíamos - requerimos retomar cosas que se quedaron en el camino, como la propuesta aprobada en esta Asamblea en 1974 de un nuevo orden económico internacional, para recordar algo, digamos lo siguiente: el Artículo 2 del texto de aquella carta confirma el derecho de los Estados de nacionalizar las propiedades y los recursos naturales, que se encontraban en manos de inversores extranjeros, proponiendo igualmente la creación de carteles de productores de materias primas. En su resolución 3.201 de mayo de 1974, expresó la determinación de trabajar con urgencia para establecer un nuevo orden económico internacional basado -óiganme bien, os ruego: En la equidad, la igualdad soberana, la interdependencia, el interés común y la cooperación entre todos los Estados, cualesquiera que sean sus sistemas económicos y sociales, que corrija las des- igualdades y repare las injusticias entre los países desarrollados y los países en desarrollo, y asegure, a las generaciones presentes $y$ futuras, la paz, la justicia y un desarrollo económico y social que se acelere a ritmo sostenido." 
Ex. 18. "Hoy reclamamos desde los pueblos, en este caso el pueblo de Venezuela, un nuevo orden económico internacional, pero también resulta imprescindible un nuevo orden político internacional. No permitamos que un puñado de países intente reinterpretar impunemente los principios del derecho internacional para dar cabida a doctrinas como la "guerra preventiva". ¡Vaya que nos amenazan con la guerra preventiva!, y la llamada ahora "responsabilidad de proteger", pero hay que preguntarse ¿quién nos va a proteger?, ¿cómo nos van a proteger?"

Ex.19. "Permítanme, una vez más, para ir concluyendo, citar a Simón Bolívar, nuestro Libertador, cuando habla de la integración del mundo, del Parlamento Mundial, de un congreso de parlamentarios, hace falta retomar muchas propuestas como la bolivariana. Decía Bolívar en Jamaica, en 1815, ya lo citaba, leo una frase de su Carta de Jamaica (...). Urge enfrentar de manera eficaz, ciertamente, al terrorismo internacional, pero no usándolo como pretexto para desatar agresiones militares injustificadas y violatorias del derecho internacional, que se han entronizado como doctrina después del 11 de septiembre. Sólo una estrecha y verdadera cooperación y el fin de los dobles raseros que algunos países del Norte aplican al tema del terrorismo podrán acabar con este horrible flagelo.."

Ex. 20. "Señor presidente, se han creado más de 700 mil puestos de trabajo, reduciéndose el desempleo en 9 puntos porcentuales; todo esto en medio de agresiones internas y externas, que incluyeron un golpe militar facturado en Washington y un golpe petrolero facturado también en Washington, pese a las conspiraciones, a las calumnias del poder mediático y la permanente amenaza del imperio y sus aliados, que hasta estimula el magnicidio. El único país donde una persona se puede dar el lujo de pedir el magnicidio de un jefe de Estado es Estados Unidos, como ocurrió hace poco con un reverendo llamado Pat Robertson, muy amigo de la Casa Blanca que pidió públicamente ante el mundo mi asesinato y anda libre. ¡Ése es un delito internacional! ¡Terrorismo internacional!

- Discurso do Presidente Hugo Chávez na 61ª Sessão Ordinária da AGNU, 
Ex.21. "En primer lugar, quiero invitar, con mucho respeto, a quienes no hayan podido leer de Noam Chomsky — uno de los más prestigiosos intelectuales de esta América y del mundo- uno de sus más recientes trabajos: Hegemonía o supervivencia, la estrategia imperialista de Estados Unidos. Excelente trabajo para entender lo que ha pasado en el mundo en el siglo XX — lo que hoy está pasando- y la más grande amenaza que se cierne sobre nuestro planeta: la pretensión hegemónica del imperialismo norteamericano pone en riesgo la supervivencia misma de la especie humana."

Ex. 22. "Ayer estuvo el diablo aquí, en este mismo lugar. ¡Todavía huele a azufre esta

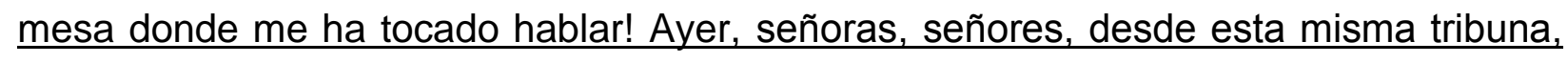
el señor Presidente de los Estados Unidos, a quien llamo "el Diablo", vino aquí, hablando como dueño del mundo. No estaría de más un psiquiatra para analizar el discurso de ayer del Presidente de los Estados Unidos. Como vocero del imperialismo vino a dar sus recetas para tratar de mantener el actual esquema de dominación, explotación y saqueo a los pueblos del mundo. Esto estaría bueno para una película de Alfred Hitchcock; incluso propondría un título: La receta del Diablo. Es decir, el imperialismo norteamericano -y aquí lo dice Chomsky con una claridad meridiana y profunda_está haciendo desesperados esfuerzos por consolidar su sistema hegemónico de dominación. No podemos permitir que eso ocurra, no podemos permitir que se consolide la dictadura mundial."

Ex. 23. "iDondequiera que él mira ve extremistas! Estoy seguro de que te ve a ti, hermano, con ese color, y cree que eres un extremista - con este color-. Evo Morales =el digno Presidente de Bolivia, que vino ayer- es un extremista, [según su criterio]. Por todos lados ven extremistas los imperialistas. No, no es que seamos extremistas, lo que pasa es que el mundo está despertando y por todos lados insurgimos los pueblos. 
Tengo la impresión, señor dictador imperialista, de que usted va a vivir el resto de sus días con una pesadilla, porque dondequiera que vea vamos a surgir nosotros, los que insurgimos contra el imperialismo norteamericano, los que clamamos por la libertad plena del mundo, por la igualdad de los pueblos y por el respeto a la soberanía de las naciones. Sí, nos llaman extremistas, insurgimos contra el imperio, contra el modelo de dominación."

Ex. 24. "Estados Unidos sigue apoyando movimientos golpistas, en Venezuela y contra Venezuela, sigue apoyando el terrorismo. Ya la presidenta Michelle Bachelet recordaba, hace unos minutos, el horrible asesinato del ex canciller chileno Orlando Letelier. Sólo agregaría lo siguiente: los culpables están libres. Los culpables de aquel hecho, donde murió también una ciudadana estadounidense, son norteamericanos, de la CIA, terroristas de la CIA. Pero, además, hay que recordar en esta sala que dentro de pocos días también se cumplirán treinta años de aquel hecho terrorista, horripilante, de la voladura del avión cubano donde murieron setenta y tres inocentes, un avión de Cubana de Aviación, ¿y dónde está el más grande terrorista de este continente, quien asumió la voladura del avión cubano como autor intelectual? Estuvo preso en Venezuela unos años y se fugó por complicidad de funcionarios de la CIA y del Gobierno venezolano de entonces. Está viviendo en Estados Unidos, protegido por este Gobierno, y fue convicto y confeso."

Ex. 25. "He hablado del avión cubano. Luis Posada Carriles se llama el terrorista, está protegido aquí, como protegidos están aquí grandes corruptos que se fugaron de Venezuela; un grupo de terroristas que allá pusieron bombas contra embajadas de varios países, que asesinaron gen- te durante el golpe de Estado, secuestraron a este humilde servidor y lo iban a fusilar, sólo que Dios metió su mano, [así como también] un grupo de buenos soldados y un pueblo que se fue a las calles; y de milagro estoy aquí. Están aquí, protegidos por el Gobierno de Estados Unidos, los líderes de aquel golpe de Estado y de aquellos actos terroristas. Acuso al Gobierno de Estados Unidos de proteger el terrorismo y de tener un discurso totalmente cínico." 
b) Ocorrências explícitas do termo terrorismo e variantes nos discursos da Venezuela na Sessão Ordinária da Assembleia Geral da ONU (1999-2006):

Tabela 3. Ocorrências explícitas "terrorismo" nos discursos de Venezuela (1999-2006)

\begin{tabular}{|l|r|r|r|r|r|r|r|r|r|}
\hline ccorréncia & \multicolumn{1}{r}{1999} & 2000 & \multicolumn{2}{r}{2001} & 2002 & 2003 & 2004 & 2005 & 2006 \\
\hline terrorismo & 0 & 0 & 3 & 10 & 6 & 3 & 3 & 2 \\
\hline terrorista & 0 & 0 & 1 & 0 & 0 & 0 & 0 & 0 \\
\hline terroristas & 0 & 0 & 0 & 3 & 0 & 1 & 0 & 3 \\
\hline terror & 0 & 0 & 0 & 1 & 0 & 0 & 0 & 0 \\
\hline total & 0 & 0 & 4 & 14 & 6 & 4 & 3 & 5 \\
\hline
\end{tabular}

\section{c) Securitização do terrorismo no ato de fala}

Figura 6. Securitização no ato de fala: Venezuela

Securitização do terrorismo nos discursos da Venezuela (2002-2006)

\begin{tabular}{|c|c|c|c|}
\hline $\begin{array}{c}\text { Quem securitiza? } \\
\text { (ator) }\end{array}$ & $\begin{array}{c}\text { O que? } \\
\text { (objeto) }\end{array}$ & $\begin{array}{c}\text { Para quem? } \\
\text { (referente) }\end{array}$ & $\begin{array}{c}\text { Por que? } \\
\text { (justificativa) }\end{array}$ \\
\hline $\begin{array}{l}\text { - Presidente Hugo Chávez } \\
\text { - O governo da Venezuela } \\
\text { - O povo da Venezuela } \\
\text { - A Venezuela } \\
\text { - O povos de bem/ } \\
\text { civilizaçăo) }\end{array}$ & $\begin{array}{l}\text { - Os terrorismos (em suas } \\
\text { diversas modalidades): } \\
\text { - Político } \\
\text { - Midiático } \\
\text { - Econômico } \\
\text { - Financeiro }\end{array}$ & $\begin{array}{l}\text { - Para a Venezuela } \\
\text { - Para o governo da } \\
\text { Venezuela } \\
\text { - Para o povo venezuelano } \\
\text { - Para a humanidade } \\
\text { - Para os pobres/oprimidos/ } \\
\text { excluidos }\end{array}$ & $\begin{array}{l}\text { - Por coloca em risco a } \\
\text { sobrevivência de/do/da(s): } \\
\text { - Presidente Hugo Chávez } \\
\text { - Governo da Venezuela } \\
\text { - Povo da Venezuela } \\
\text { - Democracia } \\
\text { - Valores universais/moral/ } \\
\text { bem/ fé cristã }\end{array}$ \\
\hline
\end{tabular}

d) Encadeamento argumentativo (frames e intertextualidade) 
Figura 7. Encadeamento argumentativo: Venezuela

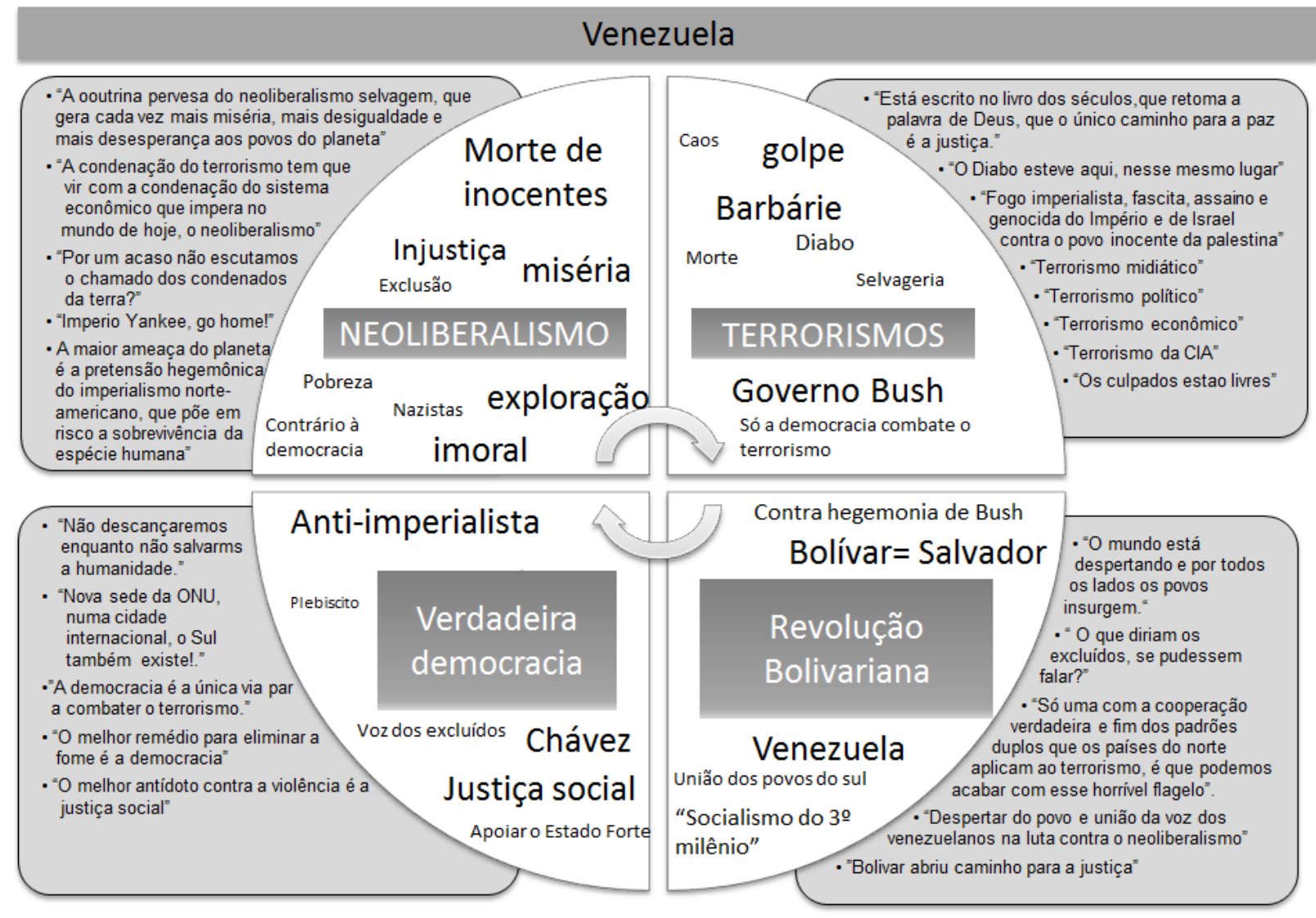

A Revolução Bolivariana é a verdadeira solução para o terrorismo, para o neoliberalismo e para a injustiça.

\section{Conclusão}

Este artigo voltou-se para os discursos dos chefes de Estado de Brasil, Colômbia e Venezuela na abertura das Sessões Plenárias da Assembleia Geral das Nações Unidas (2002-2006), para mapear os processos linguísticos e argumentativos que indicassem a macrossecuritização do terrorismo, no contexto da Guerra Global ao Terror. Sustentou-se na teoria da Escola de Copenhague, para a qual o processo de securitização se inicia por ato de fala, justificando-se análise minuciosa do Discurso.

Assumido que é pelo discurso político que os chefes de Estados buscam legitimação e neutralização de temas polêmicos, trouxeram-se as contribuições da Análise Crítica do Discurso, para a qual o discurso molda a realidade e é moldado por ela, de maneira dialética; empreendeu-se, então, a descrição do contexto 
extradiscursivo para a compreensão dos enunciados linguísticos. Selecionaram-se, assim, os fenômenos linguísticos, argumentativos e retóricos pelos quais se pudesse avaliar a securitização do terrorismo, inserida no contexto político (o interno e o externo) de cada um daqueles países.

Optou-se por identificar os tipos predominantes de modalização do discurso, já que esta está intimamente ligada à estratégia argumentativa e retórica utilizada, que visa ao convencimento da audiência (quanto à securitização da ameaça). Também, fez-se uso dos fenômenos da intertextualidade e dos frames, para que se pudesse verificar a que os presidentes se referem por terrorismo. Com esse material, foi possível identificar quem é o ator securitizador, qual é o objeto que este vê como ameaça, para quem e por quê. Concluiu-se que o governo da Colômbia e o da Venezuela macrossecuritizam a Guerra ao Terror no ato de fala, enquanto o do Brasil não a macrossecuritiza, mas incorpora o terrorismo à discussão para o combate à fome e para a reforma do Conselho de Segurança.

No caso da Colômbia, a macrossecuritização no discurso de Uribe ocorre pela adesão à agenda norte-americana da Guerra ao Terror, embora o presidente renegocie os conceitos propostos por Bush, atribuindo ao narcotráfico antecedência ao radicalismo islâmico no combate ao terror. Uribe faz amplo uso de modalizações do tipo alocutivo, jogando para o alocatário a responsabilidade do conteúdo da mensagem, com predominância da estratégia retórica do tipo patético (que visa à mobilização do páthos, das emoções da audiência), visando a legitimar a política de combate ao narcotráfico adotada por seu governo e angariar apoio internacional não só para a causa colombiana, mas para a responsabilidade compartilhada dos problema das drogas.

Já nos discursos da Venezuela, Chávez parte das mesmas premissas de que parte Bush (na NSS 2002), de que o combate ao terrorismo é tarefa moral, que pressupõe a luta entre o Bem e o Mal e por isso deve extirpar do planeta o terrorismo para se opor frontalmente à hegemonia do discurso norte-americano e às ações adotadas pelo presidente Bush. Como principal estratégia de combate ao terrorismo, que, para Chávez, advém, em última instância, do neoliberalismo e do unilateralismo norte-americano, o presidente propõe a "Revolução Bolivariana", que se sobrepõe à figura do próprio Chávez. Ao tratar do tema, Chávez evoca, constantemente, 
referências religiosas e atribui para si a legítima representação dos excluídos, dos povos do Sul, das vítimas do terrorismo e do neoliberalismo. A modalização elocutiva predomina nos discursos do presidente, que sustenta sua retórica na legitimidade que ele, Chávez, supõe gozar por ser o chefe de Estado que promove a causa de Bolívar no mundo, a quem ele considera uma espécie de sucessor de Jesus Cristo.

O Brasil, por sua vez, não macrossecuritiza o terrorismo; incorpora a discussão do terrorismo ao problema geral do combate à fome e à pobreza, cuja solução envolve a reforma da ONU e a suspensão das práticas de comércio desleal (como os subsídios agrícolas). O terrorismo, assim como outros crimes, é reflexo da fome, da exclusão e da pobreza; para combatê-lo, os governos precisam combater-lhe as causas. Por isso, nos discursos do presidente, a paz mundial está condicionada à superação das mazelas sociais no nível interno. No nível externo, as crises, que decorrem dessas mazelas, demandariam soluções multilaterais e sempre condicionadas ao respeito à soberania do Estado. Para Lula, só a ONU goza de legitimidade para combater o terrorismo e o fato de a instituição ter sido incapaz de tolher o unilateralismo e o desrespeito às normas internacionais (deixando subentendida a oposição de seu governo à guerra no Iraque) só reforça urgente necessidade de reforma do Conselho de Segurança, órgão que, segundo ele, carece de legitimidade. Lula busca o convencimento pela lógica (lógos), que se manifesta também no predomínio da modalização delocutiva, por meio da qual ele afasta de si o conteúdo da mensagem, a que atribui caráter de "verdade inquestionável".

Observou-se que Guerra ao Terror colocou o terrorismo na pauta das discussões (como se pôde observar na tabela de ocorrências explícitas do termo terrorismo) no período analisado. Suspeita-se que a alta incidência do termo terrorismo no pós-11 de setembro esteja associada não apenas ao momentum propiciado pelo ataque, mas também, em termos argumentativos, ao alto poder retórico do conceito, que, apesar das diferentes definições, aponta para as conotações comuns de "sofrimento" e de "inocentes", que se suspeita remeterem à fé cristã. Do ponto de vista discursivo, então, a força retórica do "terrorismo" tenderia a favorecer "macrossecuritização" no discurso, não pela adesão à causa em si, mas como parte de narrativas que buscam articular, negociar, renegociar, rechaçar ou legitimar temas que não necessariamente comprometem a sobrevivência do Estado (embora a articulação retórica os estabeleça como tais), mas ocupam posição prioritária na agenda de cada um daqueles governos. 
Por fim, é importante ressaltar que a análise e as conclusões apresentadas neste trabalho se referem à macrossecuritização da Guerra ao Terror no discurso (ato de fala). Por isso, os dados apresentados são insuficientes para afirmar se houve a macrossecuritização (de fato) da Guerra ao Terror na América Latina (ou seja, se a retórica resultou em ação extradiscursiva), o que faz pressupor que à análise do discurso se associe a análise dos resultados que os discursos produziram no campo extradiscursivo. Isso, no entanto, não desmerece a importância do objeto deste trabalho, já que se assume que o discurso, como prática social que é, influencia as demais práticas sociais e é influenciado por elas, que, em conjunto, constituem aquilo que entendemos por "realidade".

\section{Bibliografia}

AMARAL, Arthur Bernardes do. (2007). A Tríplice Fronteira e a guerra ao terror: dinâmicas de constituição da ameaça terrorista no Cone Sul. Carta Internacional, v. 2, n. 2, p. 48-58, 2007.

AMORIM, Celso (2004). "Conceitos e estratégias da diplomacia do Governo Luna" in Revista DEP: Diplomacia e Estratégia Política/Projeto Raúl Prebisch v01, no1 (out.2004). Brasília: Projeto Raúl Prebisch.

ARISTÓTELES (1995). Rhetoric. In Aristotle Selections. Translated by Terence lewin and Gail Fine. Indianapolis/Cambridge, Hackett Publishing Company.

BARROS FILHO, C.(2008). Ética na Comunicação. 6. Ed. São Paulo: Summus

BENVENISTE, Emilie (1974) Problèmes de linguistique générale, II, Paris, Gallimard.

BONILLA, Adrian (2003). "Una agenda de seguridad andina". In: PANEL: "Evolution of the concept of hemispheric security" (REDES). Santiago: October 28-30, 2003.

BROWNLIE, Ian (2003). International Public Law. 6” Ed. Oxford, Oxford University Press.

BUZAN, Barry; WÆVER, Ole; DE WILDE, Jaap (1998). Security: a new framework for analysis. London: Lynne Rienner.

; WAEVER, Ole (2003). Regions and powers: the structure of international security. Cambridge: Cambridge University Press. 
; WÆVEER, Ole (2009). "Macrosecuritisation and security constellations:

reconsidering scale in securitisation theory". Review of International Studies, v. 35, p. 253-276, 2009.

CHARAUDEAU, Patrick (1992). Grammaire du sens et de l'expression. Paris: Hachette Éducation.

CHÁVEZ FRÍAS, Hugo(2009) Revolución Bolivariana ante la Onu. Colección Cuadernos para el debate. Caracas: Ministerio del Poder Popular para la Comunicación y la Información.

CHRISTIE, T. B.(2006). "Framing rationale for the Iraq War". International Communication Gazette, 68(5/6), 519-532.

COBB, R. W.; ELDER, C. D. (1971). "The politics of agenda building: An alternative perspective for modern democratic theory". Journal of Politics, 33, 892-915

COLOMBIA. Missão permanente da Colômbia ante às Nações Unidas: Discursos no Plenário da Assembleia Geral da ONU, período de seções 62-55, disponíveis em: http://www.colombiaun.org/Asamblea\%20General/Comisiones/Plenario 60-55.html

CORRÊA, Luiz Felipe de Seixas (Org.) (2007). O Brasil nas Nações Unidas 1945-2006. Brasília: Fundação Alexandre de Gusmão.

DIJK, Teun A. Van. (2005). "War rhetoric of a little ally: Political implicatures and Aznar's legitimization of the war in Iraq. In: Journal of Language and Politics 4:1 (2005) 65-91.

DIJK, Teun A. Van. (2008). Discurso e poder. São Paulo: Contexto.

FAIRCLOUGH, Norman (1992). Discourse and social change. Cambridge: Polity Press.

FARAH, Douglas. (2007)."The Growing Terrorism Challenges from Latin America". International Assessment and Strategy Center. Disponível em: http://www.strategycenter.net/research/publD. 149/pub detail.asp

FERREIRA, Giovandro Marcus (2001). "As Origens recentes: os meios de comunicação pelo viés do paradigma da sociedade de massa". In: HOHLFELDT, Antonio (Org). Teorias da Comunicação - conceitos, escolas e tendências. Petrópolis: Vozes.

FERREIRA, Oliveiros S. (1986). Os 45 cavaleiros húngaros: Uma leitura dos Cadernos de Gramsci. Brasília: Editora Universidade de Brasília

FESTE, Karin (2010). Terminate Terrorism. Boulder: Paradigm Publishers .

FRANCHINI NETO, Hélio (2005). "A Política Externa Independente em ação: a Conferência de Punta del Este de 1962". Rev. bras. polít. int., Brasília , v. 48, n. 2, p. 129-151, Dec. 2005. 
GEE, James Paul (2001) How to do discourse analysis: a toolkit. New York: Routledge.

HODGES, Adam (2011). The "War on Terror" Narrative: Discourse and Intertextuality in the Construction and Contestation of Sociopolitical Reality. Oxford: Oxford University Press.

HUDSON, Rex (2003). Terrorism and Organized Crime in the Tri-Border Area (TBA) of the South America. Washington: Federal Division of Research of Library Congress. Disponível em: http://fas.org/irp/cia/product/frd0703.pdf

HOFFMAN, Bruce. (2006) Inside Terrorism. New York: Columbia University Press.

HOHLFELDT, Antonio (Org) (2001). Teorias da Comunicação - conceitos, escolas e tendências. Petrópolis: Vozes.

JARVIS, Lee (2009). Times of terror: discourse, temporality and the War on Terror. New York: Palgrave.

KALDOR, Mary (2007) New and Old wars: Organised violence in a Global Era. 2nd edition. Cambridge: Polity Press.

LEANDRO, Garcia, Tenente-general (2004) "Uma visão militar sobre o terrorismo". In: Terrorismo. Adriano Moreira, org. Lisboa: Almedina.

LITWAK, Robert. (2000) Rogue States and U.S Foreign Policy: Containment After the Cold War. Washington. D.C: Woodrow Wilson International Center for Scholars.

MARUXO Jr, José Hamilton. (2012) Percursos argumentativos labirínticos no texto de vulgarização científica. Tese de Doutorado, Faculdade de Filosofia, Letras e Ciências Humanas, Universidade de São Paulo, São Paulo.

MCCOMBS, Maxwell; SHAW, Donald (1972). "The Agenda Setting function of mass media" .in: Public Opinion Quarterly, vol. 36, n. 2. New York, 1972

MILLER, Benjamin, (2007) States, Nations and the Great Powers: the Sources of Regional War and Peace. Cambridge: Cambridge University Press.

NAIM, Moisés (2001). "The real Story Behind Venezuela's Woes". In: Journal oof Democracy, Vol. 12 (2), p. 17-31.

NARDIN, Terry (2015). "Michael Walzer's Just and Unjust Wars". Forthcoming in Oxford Handbook of the Classics of Contemporary Political Theory.

NICHOLS, T. M. \& SILVERSTONE, S. (2006) "Does Preventive War Have a Future?" the U.S. Naval College. Disponível em: http://www.fossesayshi.com/wpcontent/uploads/2014/01/BardianSpring06.pdf

NSSUS (2002). National Security Strategy of United States of America. Government Printing Office. The White House.

NYE, Joseph, Jr. (2002). O Paradoxo do Poder Americano. São Paulo: Editora da UNESP. 
OLIVEIRA, Henrique Altemani de (2005). Política Externa Brasileira. São Paulo: Editora Saraiva.

ORTIZ, Román (2008) "De la cooperación a la crisis: las relaciones de seguridad Estados Unidos-Región andina en la última década": In América Latina y la segunda administración Bush: un debate sobre seguridad / ed. por Ana Cristina Lizano. 1a ed. -San José, Costa Rica: FLACSO.

PÊCHEUX, Michel (2009). Semântica e discurso: uma crítica à afirmação do óbvio. Campinas: Unicamp.

REESE, S.D. and LEWIS, S.C. (2009) "Framing the War on Terror: internalization of policy and the US press". Journalism Sage Publications Vol.10 (6)

REITER, Dan. (2006) Preventive War and its alternatives: the lessons of history. Strategic Studies Insitute. Disponível em: http://www.StrategicStudiesInstitute.army.mil/

SARDENBERG, Ronaldo Mota (2013) O Brasil e as Nações Unidas. Brasília: FUNAG

SERBIN, Andrés (1996). "Venezuela, el Gran Viraje, and Regionalism in the Caribbean Basin". In: Gordon Mace and Jean-Phillippe Thérien (Eds.), Foreign Policy and Regionalism in the Americas. Boulder: Lynne Rienner

SMITH, P. (2005) Why War? The cultural logic of Iraq, the gulf war, and Suez. Chicago, IL: University of Chicago Press.

TAVARES, Rodrigo (2014). Security in South America. London: Lynne Reiner Publishers.

TICKNER, Arlene B (2003). "Colombia: U.S. Subordinate, Autonomous Actor or Something in Between" in Frank O, Mora and Jeanne A.K. Hey (Eds.), Latin American and Caribbean Foreign Policy. Lanham: Rowman and Littlefield Publishers.

VILLA, Rafael Duarte (2009). Novas lideranças sul-americanas: clivagens sobre o binômio estabilidade-instabilidade política. Revista de Sociologia e Política (UFPR. Impresso), v. 17, p. 71-82, 2009.

(2007). Quatro teses sobre a política de segurança dos Estados Unidos para a América do Sul. Tese (Livre-docência em Ciência Política) - Faculdade de Filosofia, Letras e Ciências Humanas, Universidade de São Paulo, São Paulo. 19, p. 153-175.

(2005). "Venezuela: political changes in the Chavez era". Estudos Avançados, v.

; VIANNA, M. T. (2010). "Security issues during Lula's administration: from the reactive to the assertive approach". Revista Brasileira de Política Internacional v. 53, p. 91-114, 2010.

WALZER, Michael (2003). Guerras Justas e Injustas: uma argumentação moral com exemplos históricos. São Paulo: Martins Fontes. 
WILLIAMS, Cindy. (2006) "Beyond Preemption and Preventive War: Increasing US Budget Emphasis on Conflic Prevention". The Stanley Foundation Analysis Brief.

WODAK, R. (2009). The Discourse of Politics in Action: Politics as usual. London: Palgrave. 